NB: This manuscript has been submitted to Earth Science Reviews on May $10^{\text {th }} 2021$, and has not undergone peer review yet.

\title{
A Persistent Non-uniformitarian Paleomagnetic Field in the Devonian?
}

Annique van der Boon ${ }^{1}{ }^{1}$, Andrew J. Biggin ${ }^{1}$, Daniele Thallner ${ }^{1}$, Mark W. Hounslow ${ }^{1,2}$, Richard Bono ${ }^{1}$, Jerzy Nawrocki ${ }^{3}$, Kristyan Wójcik ${ }^{4}$, Mariusz Paszkowski ${ }^{4}$, Peter Königshof ${ }^{5}$, Tim de Backer $^{6}$, Pavel Kabanov ${ }^{7}$, Sofie Gouwy ${ }^{7}$, Richard VandenBerg ${ }^{7}$

${ }^{1}$ Geomagnetic Laboratory, Oliver Lodge Building, Department of Physics, Oxford Street, Liverpool, L69 7ZE, United Kingdom, *AvanderBoon.work@gmail.com ${ }^{2}$ Lancaster Environment Centre, Lancaster University, ${ }^{3}$ Faculty of Earth Sciences and Spatial Management, Maria Curie-Skłodowska University, Al. Kraśnicka 2cd, 20-718 Lublin, Poland ${ }^{4}$ Polish Geological Institute - National Research Institute, Rakowiecka 4, 00-975 Warszawa, Poland, ${ }^{5}$ Senckenberg Research Institute and Natural History Museum, Senckenberganlage 25, 60325 Frankfurt, Germany, ${ }^{6}$ Department of Geology, Ghent University, 9000, Ghent, Belgium, ' Geological Survey of Canada, Calgary, AB T2L 2A7, Canada

\begin{abstract}
The Devonian, like much of the Paleozoic, has long been a problematic period for paleomagnetism. Devonian paleomagnetic data are generally difficult to interpret and have complex partial or full overprints; problems that arise in data obtained from both sedimentary and igneous rocks. As a result, the reconstruction of tectonic plate motions, performed largely using apparent polar wander paths, has large uncertainty. Similarly, the Devonian geomagnetic polarity time scale is very poorly constrained. Paleointensity studies suggest that the field was much weaker than the modern field, and it has been hypothesised that this was accompanied by many polarity reversals (a hyperreversing field). We sampled middle to upper Devonian sections in Germany, Poland and Canada which show low conodont alteration indices, implying low thermal maturity. We show in this study that there are significant issues with these data, and they are not straightforward to interpret, even though no significant heating and remineralisation was likely to have caused overprinting. We compare our data to other magnetostratigraphic studies from the Devonian and review the polarity pattern as presented in the Geologic Time Scale. Combined with estimates for the strength of the magnetic field during the Devonian, we suggest that the field during the Devonian might have been so weak and in part non-dipolar that obtaining reliable primary paleomagnetic data from Devonian rocks is challenging. Careful examination of all data, no matter how unusual, is the best way to push forward our understanding of the Devonian magnetic field. Paleointensity studies show that the field during the Devonian had a similar low strength to that recently advocated during the Ediacaran. Independent evidence from malformed spores around the DevonianCarboniferous boundary suggests that the terrestrial extinction connected to the Hangenberg event, was caused by increased UV-B radiation, supporting the weak field hypothesis. A fundamentally weak and possibly non-dipolar field during the Devonian could have been produced, in part, by true polar wander acting to maximise core-mantle heat flow in the equatorial region. It may also have influenced evolution and extinctions in this time period. There is a large-number of paleobiological crises in the Devonian, and we pose the question, did the Earth's magnetic field influence these crises?
\end{abstract}

Keywords: Magnetostratigraphy, paleomagnetism, non-dipolarity, remagnetisation, paleobiological crises 


\section{Introduction}

The Devonian Period lasted for around 60 million years, and spanned the time from 419 to 359 million years ago (Becker et al., 2020). The Devonian was a key interval in which land-plant cover expanded from a groundlevel green skin, localized in wet habitats, to extensive forests across humid regions (Le Hir et al., 2011). The first seed plants appeared in the mid-Famennian (Prestianni and Gerrienne, 2010), and the first terrestrial tetrapods in the Eifelian (Niedźwiedzki et al., 2010). Life flourished in the oceans, and in the Givetian-Frasnian the marine faunas attained their highest genus-level richness for the entire Paleozoic (e.g. Bambach et al., 2002). At the same time, reefs with a high diversity of metazoan organisms reached their peak abundance for the Paleozoic (Kiessling et al., 2003). Devonian paleogeography comprised three major continents. The largest of these, Gondwana, consisted of present-day South America, Africa, Arabia, India, Antarctica and Australia, and was positioned in the high latitudes of the southern hemisphere. Gondwana made up more than half of all landmass on Earth (Torsvik, 2019). Laurussia consisted of North America, Greenland and Baltica and was positioned in low latitudes, straddling the equator, while Siberia was positioned in the northern hemisphere (Torsvik and Cocks, 2013). During the Devonian, the terrestrial facies of the 'Old Red Sandstone' were deposited in large parts of present-day northwest Europe, Greenland and northeast North America. The climate during the Devonian was warm, indicated by a lack of glacial deposits. Throughout the Middle and Late Devonian, the atmospheric $\mathrm{pO}_{2}$ rose from $\sim 0.7$ of the present-day atmospheric level (PAL) to present-day concentration, while $\mathrm{pCO}_{2}$ dropped from 5.0-6.0 PAL to just slightly more than the pre-industrial Holocene level (Lenton et al., 2018), and this major shift in Earth surface conditions is likely linked to the spread of land vegetation, including wetland forests (Le Hir et al., 2011; Strother et al., 2010). At the end of the Devonian, the climate had cooled enough for significant ice sheets to develop (Isaacson et al., 2008). This latest Famennian glaciation in the high latitudes of Gondwana heralded the advent of the protracted icehouse termed the late Paleozoic Ice Age (Montañez and Poulsen, 2013). The Devonian was a time of many biotic crises in the marine realm, particularly in the Middle and Late Devonian. Metrics for these biotic crises evolved for almost half a century based on the Paleobiology Database (https://paleobiodb.org). As reviewed by McGhee et al. (2013), the genus-level taxonomic loss places four Devonian extinctions (Frasnian-Famennian, late Givetian, latest Famennian, and latest Eifelian) in the 10 most severe extinctions of the post-Cambrian Phanerozoic. These same events also enter the top-ten list based on the estimate of their ecologic severity (McGhee et al., 2013). Other events during the Devonian were taxonomic radiations, a cascade of evolutionary innovations in marine faunas and sudden spreads of marine organisms linked to transgressions (Becker et al., 2016). Causes for nearly all of these perturbations are still heavily debated (e.g. Bond et al., 2004; Aretz, 2021; Boyer et al., 2021; Fields et al., 2020; Kaiho et al., 2021; Marshall, 2020; McGhee and Racki, 2021; Paschall et al., 2019). Many of the perturbations share similarities, as most are coincident with spreads of shelfal anoxia and linked effects (e.g. narrowing benthic habitats and ocean acidification), and many biotic events are linked to marine transgressions. There are two major mass extinctions during the Late Devonian, one at the FrasnianFamennian boundary and one at the Devonian-Carboniferous boundary. Nearly all of the Devonian events are accompanied by black shale deposition with a shallow, often photic-zone chemocline fluctuating in the water column (Kabanov and Jiang, 2020), and the nature and magnitude of sea-level fluctuations during the Devonian is also a matter of debate (Carmichael et al., 2019; Kabanov and Jiang, 2020).

Since the early days of paleomagnetism, researchers have primarily focused on obtaining paleopoles from Devonian rocks in order to reconstruct paleolatitudes and motions of the continents. However, Devonian paleomagnetic data have been troubling, with many later studies arguing that data from previous studies were unreliable due to later remagnetisations (e.g. Abrajevitch et al., 2007; Aifa, 1993; Aifa et al., 1990; Bachtadse et al., 1987; Bachtadse and Briden, 1991, 1990, 1989; Briden et al., 1984; Huang et al., 2000; Schmidt et al., 1986; Smethurst and Khramov, 1992; Stearns et al., 1989). Although there is a wealth of studies that have attempted to obtain Devonian paleopoles, only very few datasets are considered good quality (Van der Voo's $Q>3$; Van der Voo, 1990). This has resulted in a scarcity of reliable data for the reconstruction of apparent 
polar wander paths (Torsvik et al., 2012). This dearth of data affects to a larger extent the known geomagnetic polarity time during the Devonian (see Figure 1). Although polarity patterns are presented for the Early and part of the Middle Devonian (Becker et al., 2012), and more recently also for the Late Devonian (Becker et al., 2020; Hansma et al., 2015; Ogg et al., 2016a), a large portion of the Devonian is still unresolved in detail (grey in the timescale). The polarity patterns have furthermore not been confirmed through studies of sections in different parts of the world, or are based on data that is poorly accessible (Early and Middle Devonian; e.g. Guzhikov, 2019; Ogg and Smith, 2004). Thus, there is a strong need for new magnetostratigraphic studies in the Paleozoic, and especially the Devonian. Studies on the strength of the magnetic field (paleointensity), show that the Earth's magnetic field during the Devonian was very weak (Hawkins, 2018; Hawkins et al., 2020, 2019; Shcherbakova et al., 2017). Several studies have also posed the hypothesis that the field was non-dipolar in some time intervals (Shatsillo and Pavlov, 2019; Shcherbakova et al., 2017).

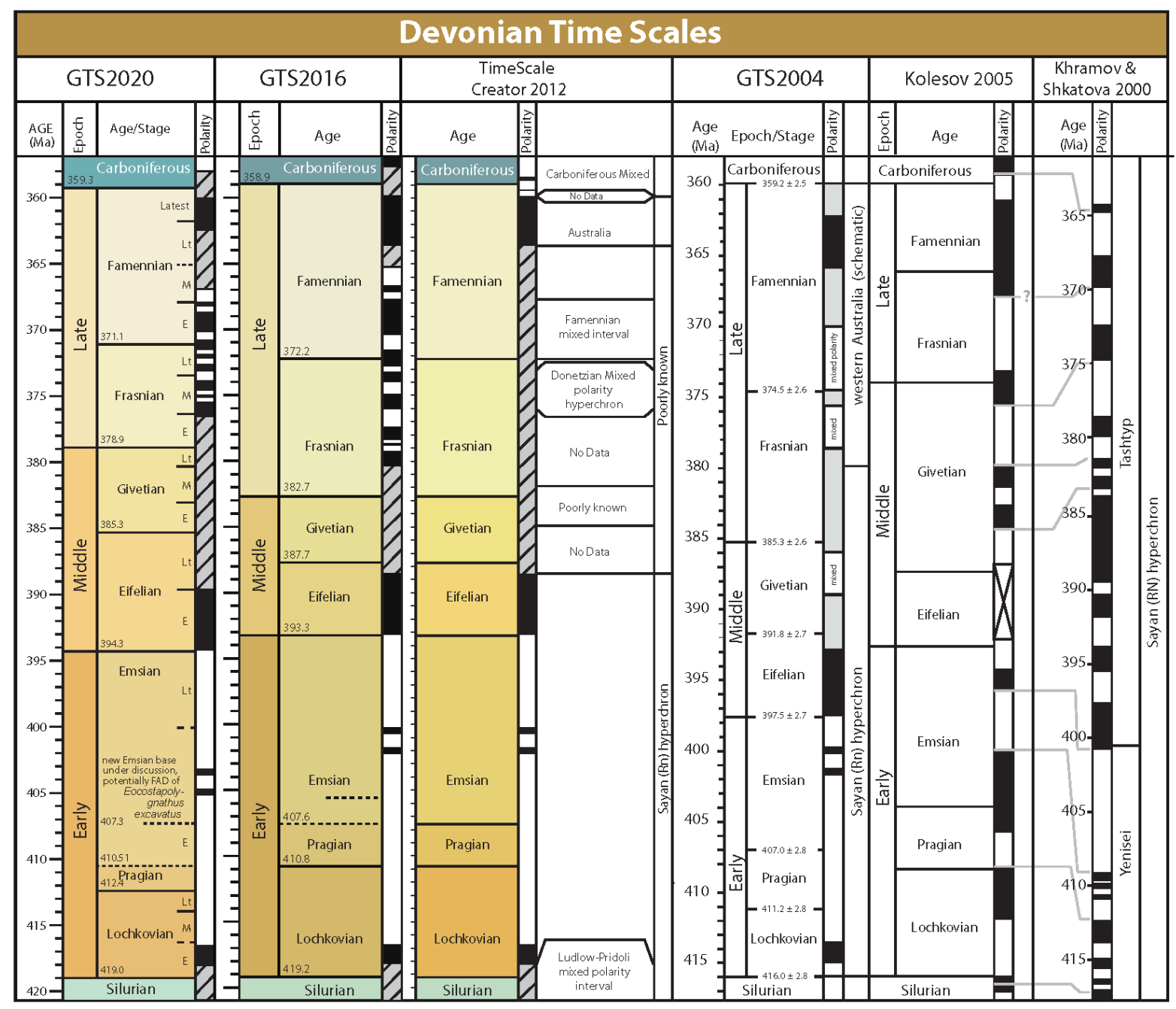

Fig. 1 - A comparison between different timescales. The 2020 timescale is from Becker et al. (2020). The 2016 timescale is from Ogg et al. (2016a), and is similar to the 2012 version of Becker et al. (2012) with the addition of the data from the Canning basin of Hansma et al. (2015). The 2012 timescale is made using TSCreator version 6.2 which is based on Becker et al., (2012). The 2004 timescale is from House and Gradstein (2004). The Russian time scale comparisons are modified after Kolesov (2005), who compares new results from outcrops from the Magadan, Sakha and Chukotka regions (far east Russia) to the timescale of Khramov and Shkatova (2000).

\subsection{This study}

We set out to sample different Devonian sections, which overlap in age with each other, or with the single existing Devonian magnetostratigraphic record from the Canning Basin in Australia (Hansma et al., 2015), in 
order to compare the results. We selected sections that had a low thermal maturity, indicated by a low conodont colour alteration index (CAl; Epstein et al., 1977; Rejebian et al., 1987) and Tmax parameter of programmed pyrolysis (Peters and Cassa, 1994). CAl values of less than 3 indicate that the sediments were heated up to an estimated maximum temperature of $200^{\circ} \mathrm{C}$ (e.g. Königshof, 2003), which could permit preservation of primary Devonian signals. A Tmax of less than $465^{\circ} \mathrm{C}$ is an indication that the kerogen thermal maturation did not proceed beyond the oil window (Peters and Cassa, 1994). We explored promising sections that also showed little evidence of remineralisation, in order to maximise chances that these sections preserved a primary signal of the Devonian magnetic field. We sampled three sections for magnetostratigraphy, in Germany, Poland and Canada, of Middle Devonian to Mississippian age (see Fig. 2). We compare our data to the body of published paleomagnetic studies and review the Devonian geomagnetic polarity timescale, paleopoles and paleointensity data. We explore explanations for the prevalence of suboptimal data and controversial findings in this time period. We consider several candidate explanations and present a new hypothesis purporting that the paleomagnetic field was non-uniformitarian through some or all of the Devonian and that this may explain the "Devonian paleomagnetic wasteland" as well as other geological phenomena reported at this time in Earth's history.

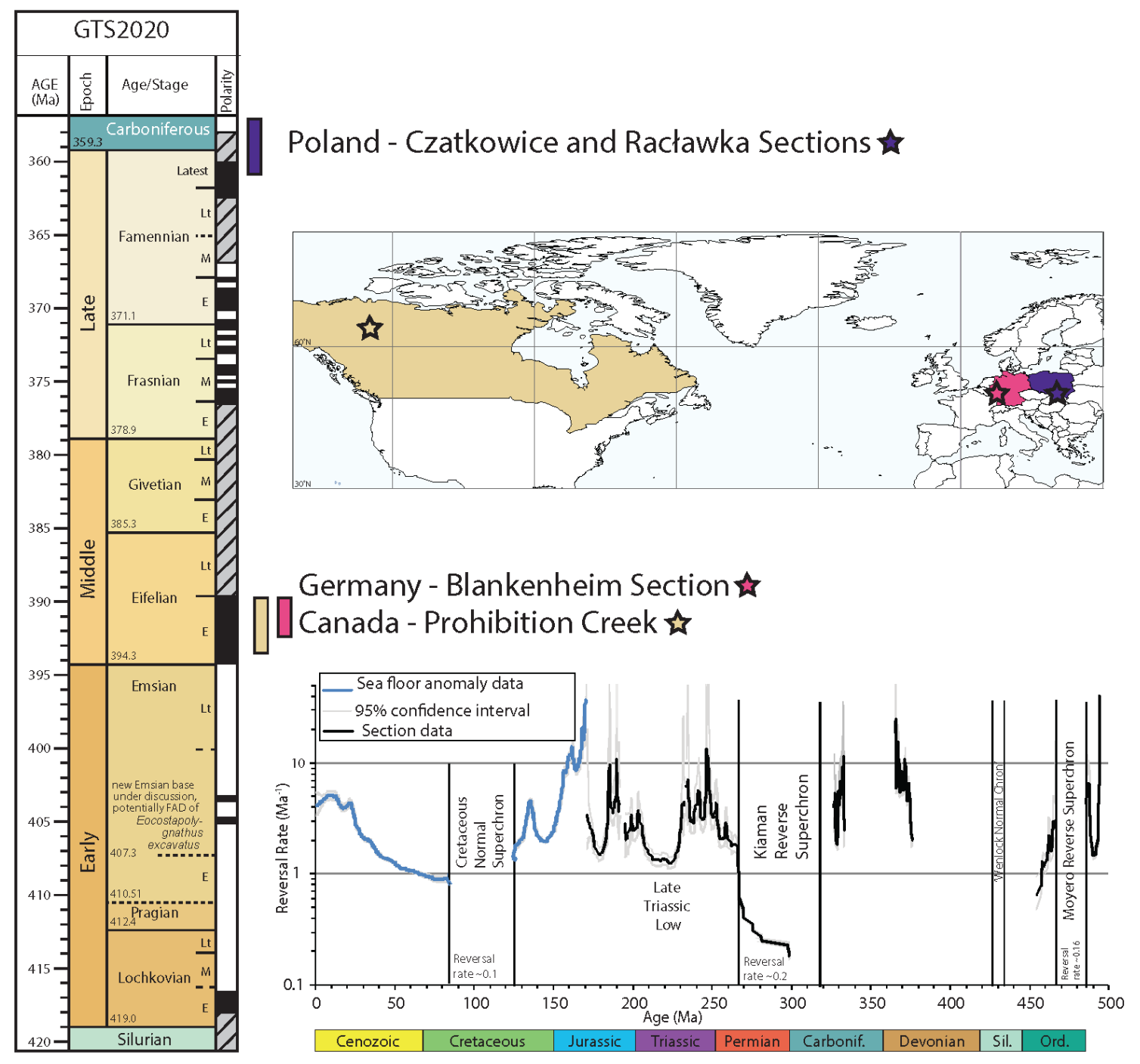

Fig. 2 - The three sampled sections with a map of their locations and the timescale from Becker et al. (2020) and reversal rates for the timescale down to the beginning of the Ordovician from Hounslow et al. (2018). 


\section{Geologic setting}

\subsection{Germany}

The Blankenheim section in the Eifel region of Germany $\left(50.44104^{\circ} \mathrm{N}, 6.63705^{\circ} \mathrm{E}\right)$ comprises ca. $8 \mathrm{~m}$ shales and carbonates (Junkerberg Fm and Freilingen Fm) of Eifelian age (Königshof et al., 2016). The section covers most of the Tortodus kockelianus conodont zone. Although the lower boundary of this conodont zone is unconstrained, the top of the section contains the upper boundary of the kockelianus Zone with the overlying Polygnathus ensensis Zone (transition from the Junkerberg Fm to the Freilingen Fm; Fig. 3). Colour alteration indices for the Blankenheim section possess some of the lowest values known for Devonian conodonts, around 1.5-2.0, indicating very low thermal maturity, equating to temperatures of a maximum of $80^{\circ} \mathrm{C}$ (Königshof, 2003; Königshof et al., 2016).
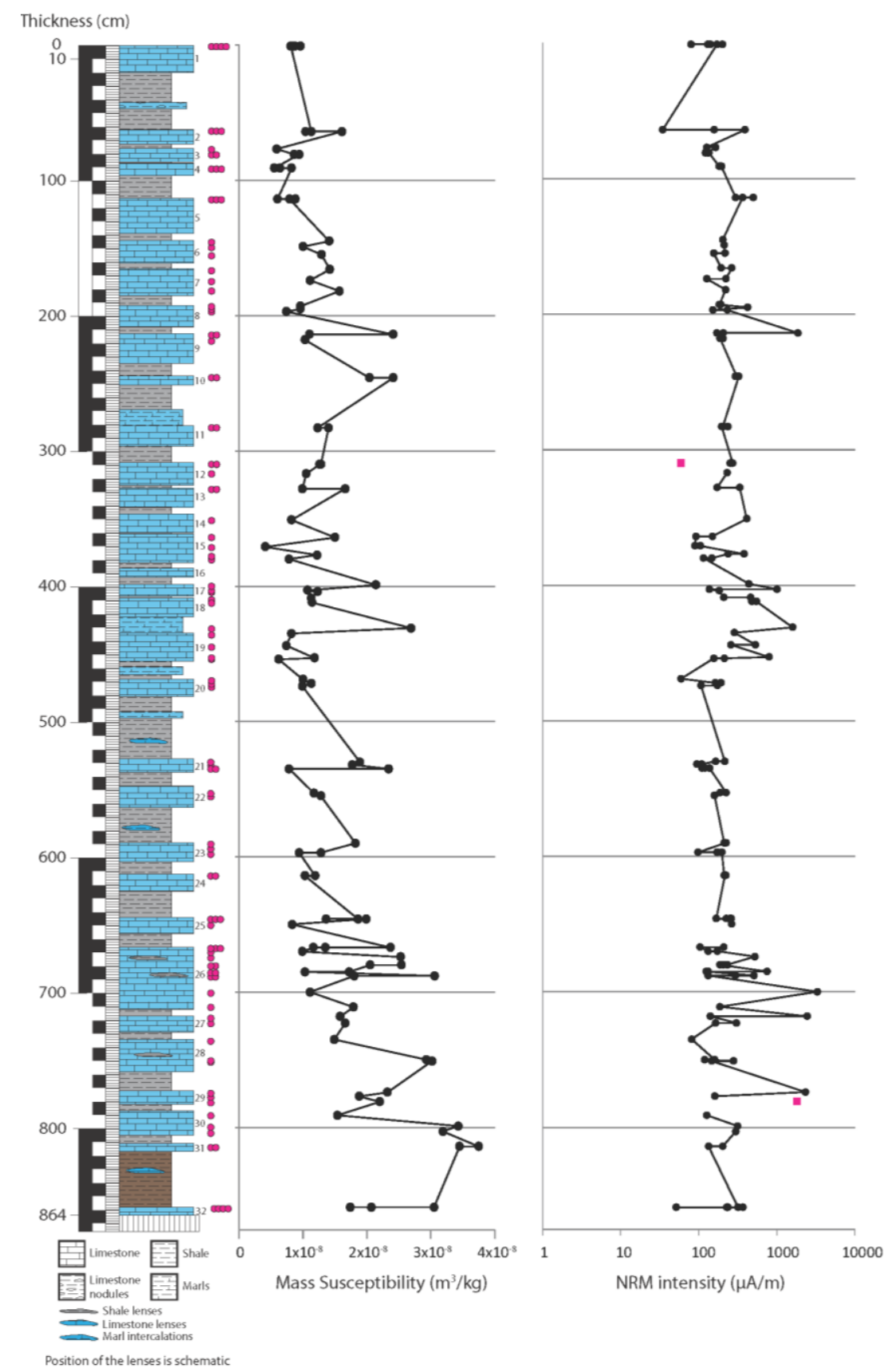

Fig. 3 - Lithological log of the Blankenheim section with sample positions, bulk magnetic susceptibility and NRM intensity (measurements in pink have uncertainties of $>20 \%$ ). 


\subsection{Poland}

The Racławka and Czatkowice sections are located in the south of Poland, near the city of Krakow (Krzeszowice area). The Czatkowice section $\left(50.15944^{\circ} \mathrm{N}, 19.64142^{\circ} \mathrm{E}\right)$ is the longer of the two, and is in an active quarry. The Racławka section is located in a valley to the northeast of Czatkowice $\left(50.17872^{\circ} \mathrm{N}, 19.68244^{\circ} \mathrm{E}\right)$. Both sections contain latest Devonian-earliest Carboniferous carbonates, which are correlated to the Mississippian of Belgium based on a foraminifer and coral biostratigraphy (Poty et al., 2003). Southern Poland was part of the Moravia-Silesia Basin during the Late Devonian and Early Carboniferous, with the study region forming part of a carbonate platform that existed from the Eifelian (Middle Devonian) to the Viséan (mid Early Carboniferous; Belka et al., 1996; Poty et al., 2003; Szulczewski and Dvorák, 1995; Wójcik, 2012). The succession of Carboniferous carbonates in the Czatkowice quarry is almost one kilometre thick and made up mostly of shallow-water carbonates. The stratigraphic interval sampled from the Czatkowice quarry ranges from the Racławka Formation, containing the Devonian-Carboniferous boundary in the eastern quarry front, to the Czerna Formation of Viséan age (Paszkowski, in: Dvorák et al., 1995; Poty et al., 2003). Conodont biostratigraphy on the Przy Granicy Formation indicates a late Tournaisian age (Gnathodus cuneiformis zone; Appelt, 1998). Nearly 100 samples from 32 levels were collected during several field campaigns from 20162018 (Figure 4). CAl values at Czatkowice and Racławka are around 1 although other areas closer to Permian intrusions have higher CAI (Belka, 1993).

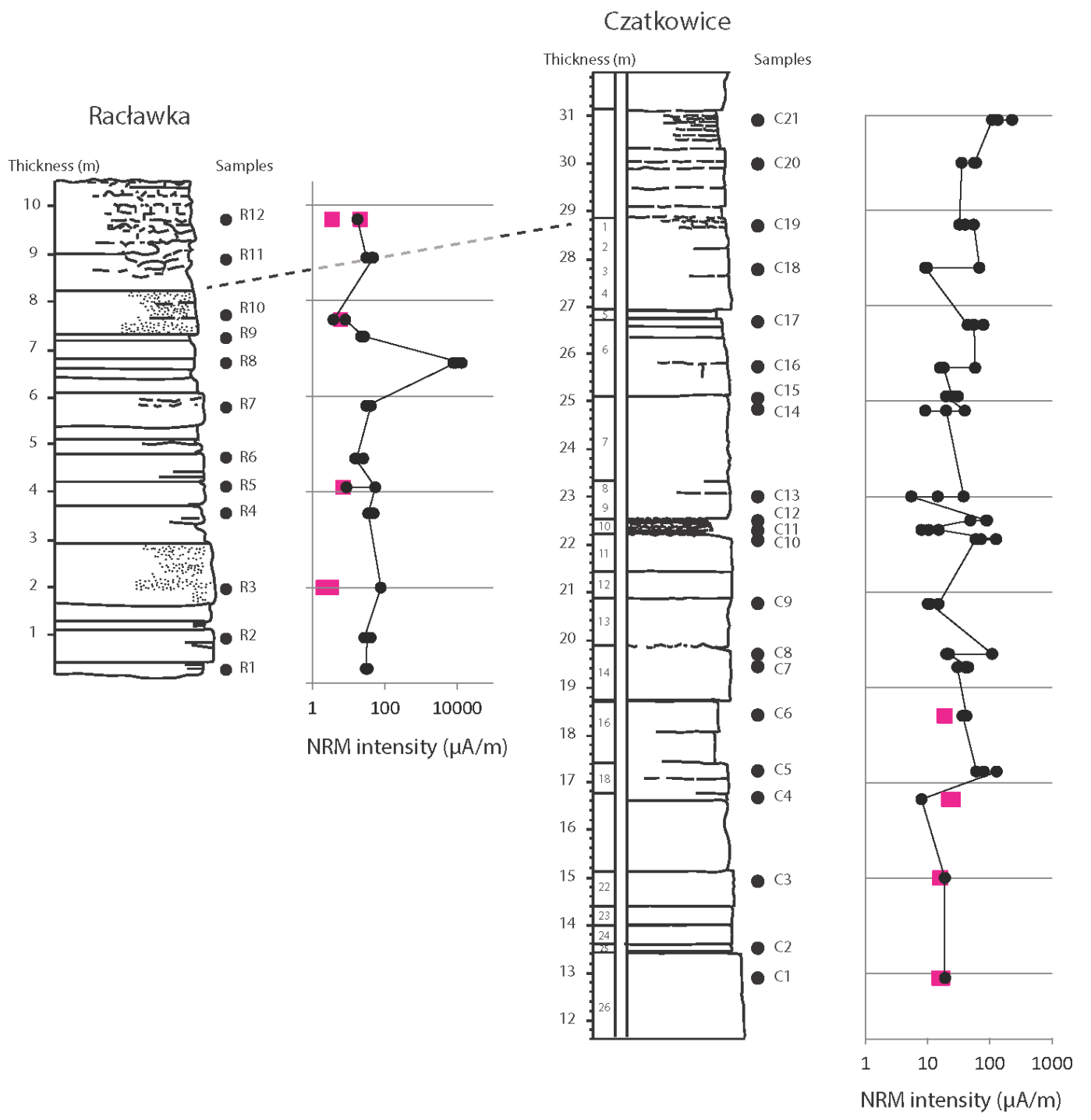

Fig. 4 - Lithological logs and correlation of the Racławka and Czatkowice sections, sampled levels and NRM intensity (measurements in pink have uncertainties of $>20 \%$ ). 


\subsection{Canada}

Prohibition Creek $\left(65.18776^{\circ} \mathrm{N}, 126.22096^{\circ} \mathrm{W}\right)$ is located near Norman Wells, in the centre of the Sahtu First Nation Lands of the Northwest Territories in Canada. It is a small creek that cuts the Franklin Mountains and feeds into the Mackenzie River. Outcrops along Prohibition Creek range in age from Cambrian to Late Devonian (Fallas and McNaughton, 2013). We assessed the Middle Devonian limestones of the Hume Formation and the basinal mudrocks of the Middle Devonian Hare Indian and Frasnian Canol Formations (Kabanov, in press). For an extended description of these units in Prohibition Creek, see Kabanov et al. (2019). Our initial aim was to capture the full section, but the Hare Indian and Canol shales were found too fissile to acquire core plugs. We then decided to focus on the limestones of the Hume Formation. Like the Blankenheim section, the Hume Formation covers the Tortodus kockelianus Zone of the Eifelian (Gouwy, 2021). In the Hume type section along the Hume River, the base of the Hume Fm is in the Tortodus australis Zone of earliest Late Eifelian age (Uyeno et al., 2017). The top of the Hume Fm, like the Blankenheim section, is in the Polygnathus ensensis Zone. The section that we sampled in Prohibition Creek in this study covers the top of the Hume Fm, and the lower part of the Hume Fm was not sampled, so comparisons with thickness between the Hume River and Prohibition Creek sections are difficult. The thickness of the Hume Fm has been estimated at 114.3 metres (Gouwy et al., 2021). The Prohibition Creek section was selected for its location in the zone of low thermal maturity where Tmax is within $426-465^{\circ} \mathrm{C}$ and where organic-matter biomarkers are well preserved (Kabanov and Jiang, 2020). Like the Blankenheim section, the CAI values in Prohibition Creek are very low (1.5-2.0; Gouwy, 2006). Because the Blankenheim section and the Prohibition Creek section both cover the same interval, they provide an excellent opportunity for comparison of paleomagnetic records from two different parts of the globe during the Eifelian. A lithological log of the section with sample positions is shown in Figure 5.
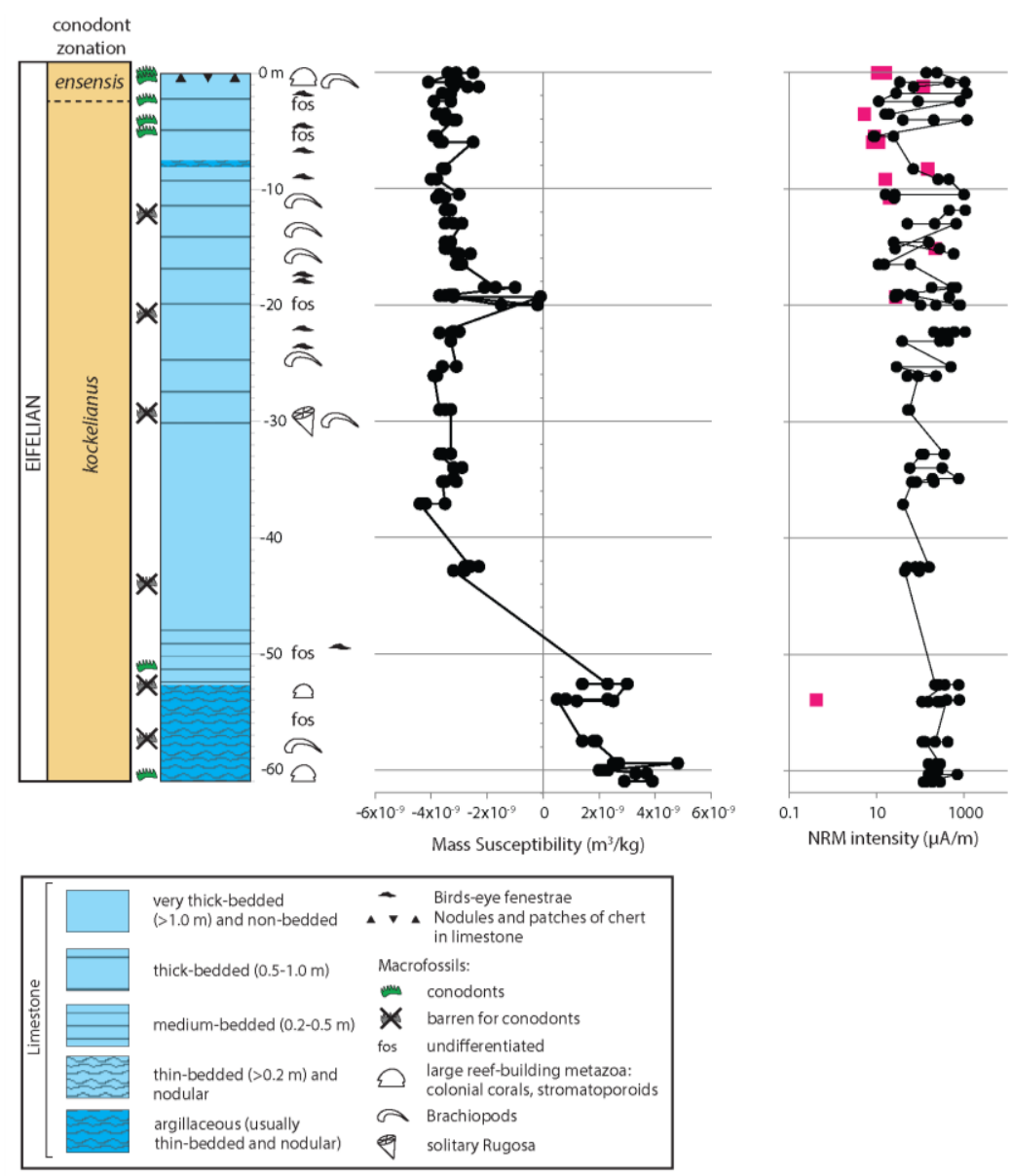

Fig. 5 - Lithological log of the Hume Formation with sampled levels, bulk magnetic susceptibility and NRM intensity (measurements in pink have uncertainties of $>20 \%$ ). The log is modified after Kabanov et al. (2019). 


\section{Methods}

\subsection{Germany}

In July 2019, 100 samples were taken for magnetostratigraphy of carbonates of the Blankenheim section. Shales in the section were too fissile and no cores could be drilled in this lithology. Standard paleomagnetic cores $(25 \mathrm{~mm} \varnothing$ ) were drilled using a gasoline-powered motor drill, and oriented using a magnetic compass. Directions were corrected for a present-day declination (International Geomagnetic Reference Field; IGRF) of $2^{\circ}$. Cores were subsequently cut into specimens of $\sim 22 \mathrm{~mm}$ long. Specimens were processed at the University of Liverpool. A total of 39 specimens were subjected to stepwise thermal demagnetisation, 40 were demagnetised using alternating field (AF) demagnetisation, and another 29 specimens were demagnetised using a combination of thermal and AF demagnetisation. Thermal demagnetisation was performed by progressive heating in a shielded furnace for one hour, taking steps of $20-55^{\circ} \mathrm{C}$, up to $400{ }^{\circ} \mathrm{C}$. AF demagnetisation was performed on the automated RAPID 2G-Entreprises Superconducting Rock Magnetometer (hereafter referred to as "RAPID"), equipped with three DC-SQUIDS, and a noise level of $10^{-12}$ $\mathrm{Am}^{2}$, which measures a singly positioned sample for four measurements of each axis. As specimens were weak, we flipped the samples and measured four positions again after each step, so each specimen was measured eight times in total per step. Typical holder magnetisations were around $10 \%$ of the NRM of the specimens.

For samples of all locations, vectors were calculated using principal component analysis (Kirschvink, 1980) on Zijderveld diagrams (Zijderveld, 1967) in the interpretation portal of Paleomagnetism.org (Koymans et al., 2016). As the bedding of the Blankenheim section is subhorizontal, there is no tectonic correction on the directions. Mean directions were calculated using Fisher statistics (Fisher, 1953). We determined great circles for two components with overlapping blocking temperatures or coercivity. Lines and planes were determined following an eigenvector approach (Kirschvink, 1980). We use the method of McFadden and McElhinny (1988) to determine great circle solutions.

Susceptibility versus temperature runs up to $700{ }^{\circ} \mathrm{C}$ in air were performed using an MFK-1 Kappabridge with CS4 furnace with a sensitivity of $10^{-7} \mathrm{SI}$. Multiple heating $\left(6^{\circ} /\right.$ minute) and cooling runs $\left(10^{\circ} /\right.$ minute) were performed.

\subsection{Poland}

Oriented hand samples were taken from the Racławka section ( $R$ samples) and Czatkowice quarry (C samples), from which conventional paleomagnetic cores $(25 \mathrm{~mm} \emptyset)$ were drilled in the paleomagnetic laboratory of the Polish Geological institute. 24 hand samples from the Czatkowice quarry were taken, as well as 12 of the Racławka section. The sampled part for this study contains the uppermost part of the Racławka Formation, as samples were taken close to the Devonian-Carboniferous boundary. A tentative correlation between the Racławka and Czatkowice sections was based on the position of characteristic oolite-layer assumed as Devonian-Carboniferous boundary interval (Fig. 4). Samples were processed at the Paleomagnetic laboratory Fort Hoofddijk, of Utrecht University, the Netherlands. In total 98 specimens were subjected to thermal (66 specimens) and alternating field (AF; 98 specimens) demagnetisation. Thermal demagnetisation was performed in a magnetically shielded furnace to maximum temperatures of $340{ }^{\circ} \mathrm{C}$, using temperature increments of $20-60^{\circ} \mathrm{C}$. Thermally demagnetised specimens were treated with AF demagnetisation to avoid alteration by a chemical remanent magnetisation (cf. van Velzen and Zijderveld, 1995). AF demagnetisation was performed with steps of 4-10 mT using an in-house built robotized system (dynamic range $3 \times 10^{-12}$ to $5 \times$ $10^{-5} \mathrm{Am}^{2}$; Mullender et al., 2016). After each demagnetisation step, the natural remanent magnetisation (NRM) was measured eight times on a $2 \mathrm{G}$ Enterprise horizontal cryogenic magnetometer equipped with three DC SQUIDS (noise level $3 \times 10^{-12} \mathrm{Am}^{2}$ ). Typical holder magnetisations were around $10 \%$ of the NRM of the samples. Thermomagnetic runs were performed on powdered samples, using a modified horizontal translation 
Curie balance with a cycling field, usually 150-300 mT (Mullender et al., 1993). Six cycles of heating and cooling were performed, up to a temperature of $700{ }^{\circ} \mathrm{C}$. Isothermal remanent magnetisation (IRM) acquisition curves were obtained, performing orthogonal IRM thermal demagnetization, up to $700 \mathrm{mT}$. The IRM was subsequently measured by use of the robotized SQUID magnetometer. Kappabridge measurements were performed at the geomagnetism laboratory of the University of Liverpool, using the AGICO MFK-1 with a furnace attachment. Six heating and cooling cycles were performed on powdered samples up to a temperature of $700^{\circ} \mathrm{C}$. Samples are repeatedly heated and cooled, after which the susceptibility is measured. Declination (D) and inclination (I) angles were calculated for pre-tilt (TC) and post-tilt (NOTC) signals.

\subsection{Canada}

More than 115 samples were taken at 44 levels of over 60 metres of section of the Hume Formation, as well as 6 samples from 3 levels of the Canol shale. Sampling methods and lab procedures were the same as described earlier for the samples from Germany. All measured orientations in the field were corrected for a local declination of $20^{\circ}$ (IGRF). A total of 40 specimens were subjected to stepwise thermal demagnetisation, 12 were demagnetised using alternating field (AF) demagnetisation, and another 81 specimens were demagnetised using a combination of thermal and AF demagnetisation.

\section{Results}

\subsection{Germany}

\subsubsection{Temperature-dependent magnetic susceptibility}

Magnetic susceptibility is usually below $10 \times 10^{-6} \mathrm{SI}$ at the start of the experiment. Magnetic susceptibility increases slightly upon heating, after which a drop follows at a temperature of $\sim 580^{\circ} \mathrm{C}$, the Curie temperature of magnetite (Fig. 6). All specimens show a peak just before $580^{\circ} \mathrm{C}$, which could be a Hopkinson peak (e.g. Dunlop, 2014) which is indicative of single domain(SD)/pseudo-single domain (PSD, or vortex state; Roberts et al., 2017) magnetite. Alternatively, this peak could be related to alteration, which is often the case in sediments. Susceptibility generally is much higher after heating, showing irreversible behaviour from between 300 and $400^{\circ} \mathrm{C}$, indicating the formation of new magnetic minerals. This is also seen by the large susceptibility increase upon cooling below $600^{\circ} \mathrm{C}$.

\subsubsection{Directions}

Samples generally have NRM intensities of tens to hundreds of microamperes per metre. Due to these weak intensities, measuring on the RAPID magnetometer was challenging, and the RAPID would often give erratic measurements (seen in measurements as a 'quadrature pattern', which happens when the background field inside the system is higher than the moment of the specimen and holder together), indicated by high uncertainties. To avoid these erratic measurements, we sometimes measured specimens several times, and removed all measurements that have standard deviation larger than $20 \%$ of the signal for interpretation. All demagnetisation data are provided in the supplementary information (files S1, S3 and S6).

Demagnetisation behaviour generally does not define only linear segments on Zijderveld plots, but many specimens exhibit incomplete component separation characterised by demagnetisation paths along greatcircles. All samples except for one contained a low temperature/low coercivity (LC) component in the direction of the modern field, in some cases, this could not be removed (see Fig. 7A). A large proportion of samples shows a strong reversed (possibly Kiaman-age) overprint, which in many cases cannot be fully demagnetised (see Fig. 7B and 7C). Characteristic remanent magnetisation (ChRM) generally decreases towards the origin of the Zijderveld diagrams (see Fig. 7), although some specimens cluster (Fig. 7E and 7F) and in some cases, the paths seem to pass the origin (see Fig. 7G). The low temperature/coercivity (LT) component has a mean 
direction of $D=11.9^{\circ}, I=66.2^{\circ}, \alpha_{95}=3.0^{\circ}$ (Fig. 8a). Although the declination is slightly high, the inclination agrees well with expected directions of the GAD (geocentric axial dipole) field (around $67.6^{\circ}$ ).
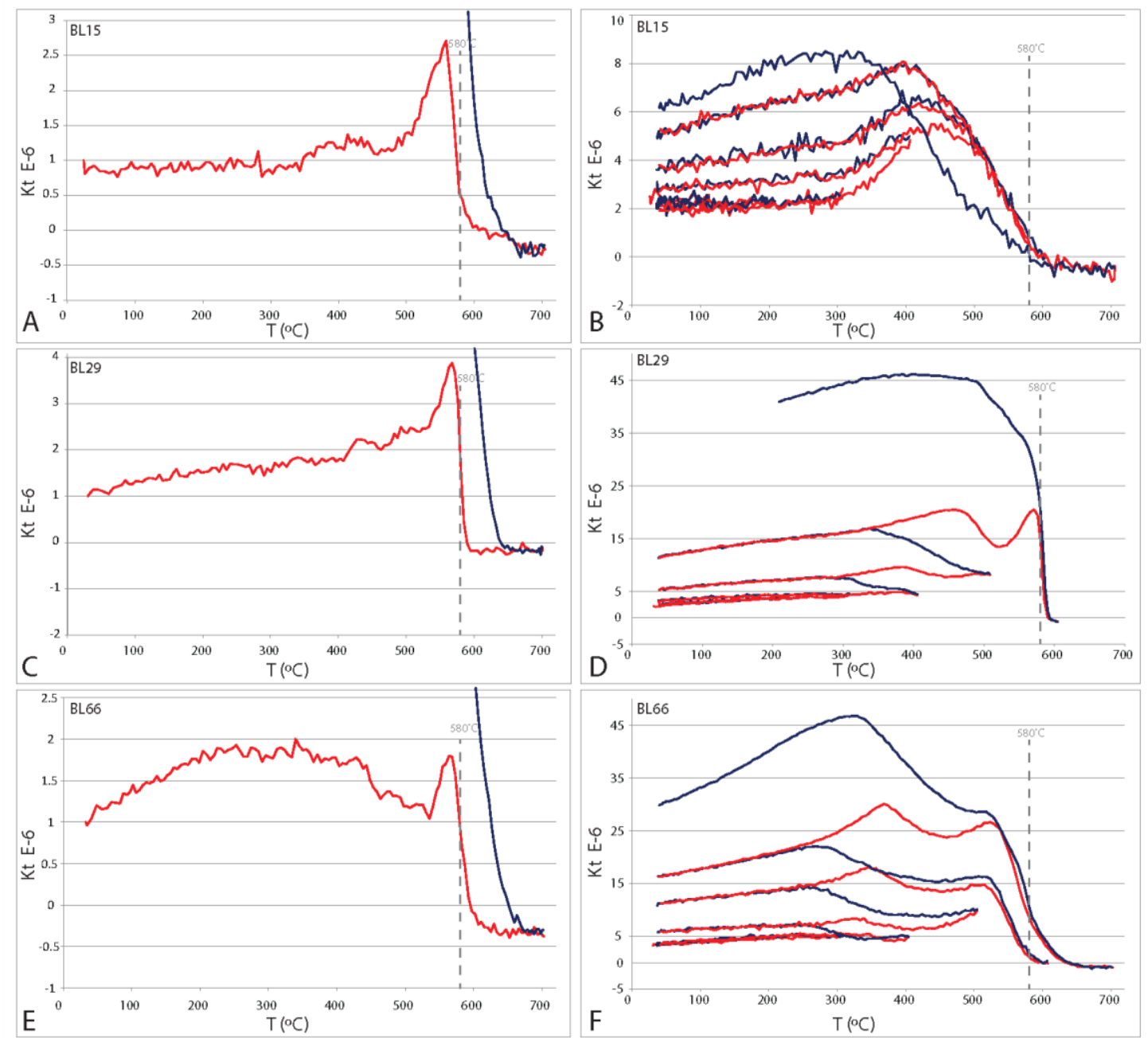

Fig. 6 - Kappabridge susceptibility versus temperature runs of three samples of limestones from the Blankenheim section. On the left are single runs, on the right are multi-segment runs. Red lines indicate heating curves, blue lines are cooling curves. The Curie temperature of magnetite $\left(580^{\circ} \mathrm{C}\right)$ is indicated with a grey dashed line.

Around half of the samples show a strong southerly and negative middle stability component (MT), which in most cases remains at the highest demagnetisation steps (see Fig. 7B and 7C). This component has a mean of $D=204.9^{\circ}, I=-24.2^{\circ}, \alpha_{95}=5.1^{\circ}$ (see Fig. 8B). The APWP (apparent polar wander path) of Torsvik et al. (2012) predicts directions (converted to reverse polarity) for the Kiaman superchron, ( $320-260 \mathrm{Ma})$, of dec $\approx 205^{\circ} \pm$ $5^{\circ}(320 \mathrm{Ma})$ to $\mathrm{dec} \approx 202^{\circ} \pm 3^{\circ}(260 \mathrm{Ma})$ and inc $\approx 12^{\circ} \pm 9^{\circ}(320 \mathrm{Ma})$ to inc $\approx-34^{\circ} \pm 4^{\circ}(260 \mathrm{Ma})$. The reverse directions that we observe in many samples agree well with Kiaman directions as expected for the location of Blankenheim (see stars in Fig. 8B) between $320 \mathrm{Ma}$ and $260 \mathrm{Ma}$. The medium temperature/coercivity (MT) directions are closer to the predicted directions at $260 \mathrm{Ma}$, so we consider this component to have been acquired during the Permian. Ribbert (1983) mentions that orogenesis in the region occurred during the late Carboniferous, which could have resulted in overprinting. Zwing and Bachtadse (2000) report a Kiaman overprint in the Rhenish Massif with a direction of $\mathrm{dec}=186.3^{\circ}$, inc $=8.0^{\circ}$, indicating that the direction in their study could represent an older overprint compared to our Blankenheim reverse polarity Kiaman directions (no overlapping $\alpha_{95}$ cones).

The characteristic remanent magnetisation (ChRM) generally decreases towards the origin of the Zijderveld diagrams (see Fig. 7), although in some samples the ChRM does not fully demagnetise (Fig. 7E and 7F), and in 
other cases misses the origin (Fig. 7G). The mean of the ChRM component is dec $=207.5^{\circ}$, inc $=33.8^{\circ}$ and $\alpha_{95}=$ 8.5. Reported directions for the Late Devonian in Rhenish Massif are around dec $=200^{\circ}$ inc $=40^{\circ}$ for reverse polarity samples (see Fig. $8 \mathrm{C}$; closed blue star), and dec $=10^{\circ}$, inc $=-43^{\circ}$ for normal polarity samples (see Fig. $8 C$; open blue star) (Zwing and Bachtadse, 2000). The ChRM components (69 directions and 2 great-circle solutions) in the Blankenheim section overlap with the Late Devonian reverse polarity direction of Zwing and Bachtadse (2000). We note, however, that this direction is also an intermediate direction between a present day field and a Kiaman overprint, and in some cases, it seems likely the Kiaman direction is not fully resolved (see for example Fig. 7D and 7I). About half, 73 specimens, did not yield ChRM directions, and only showed low temperature components or Kiaman directions. We do not observe any directions resembling a Devonian normal polarity.

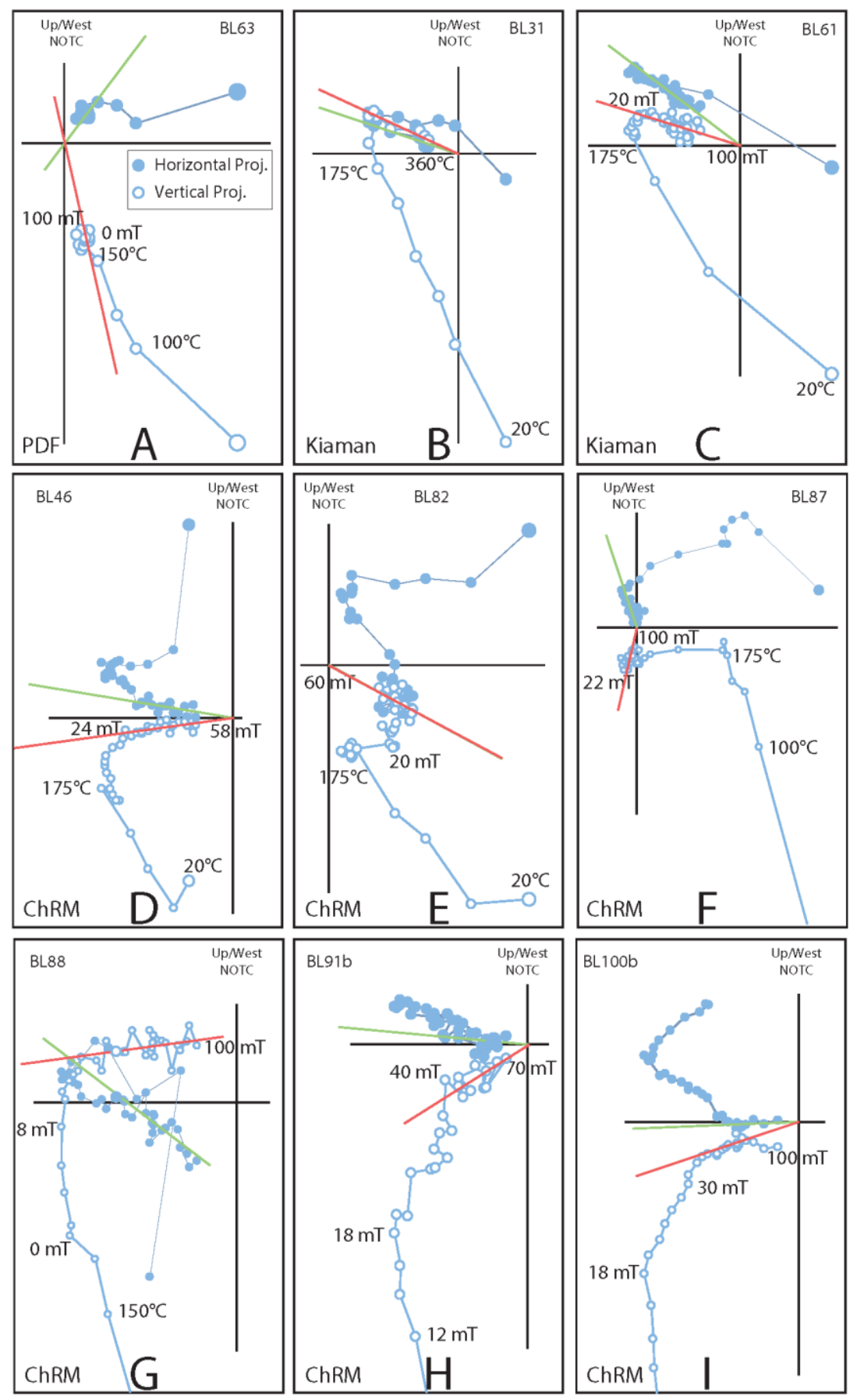

Fig. 7 - Examples of representative Zijderveld diagrams of samples from the Blankenheim section with interpreted vectors (red and green lines). As bedding in the section is subhorizontal, tectonic corrections are not applicable. 

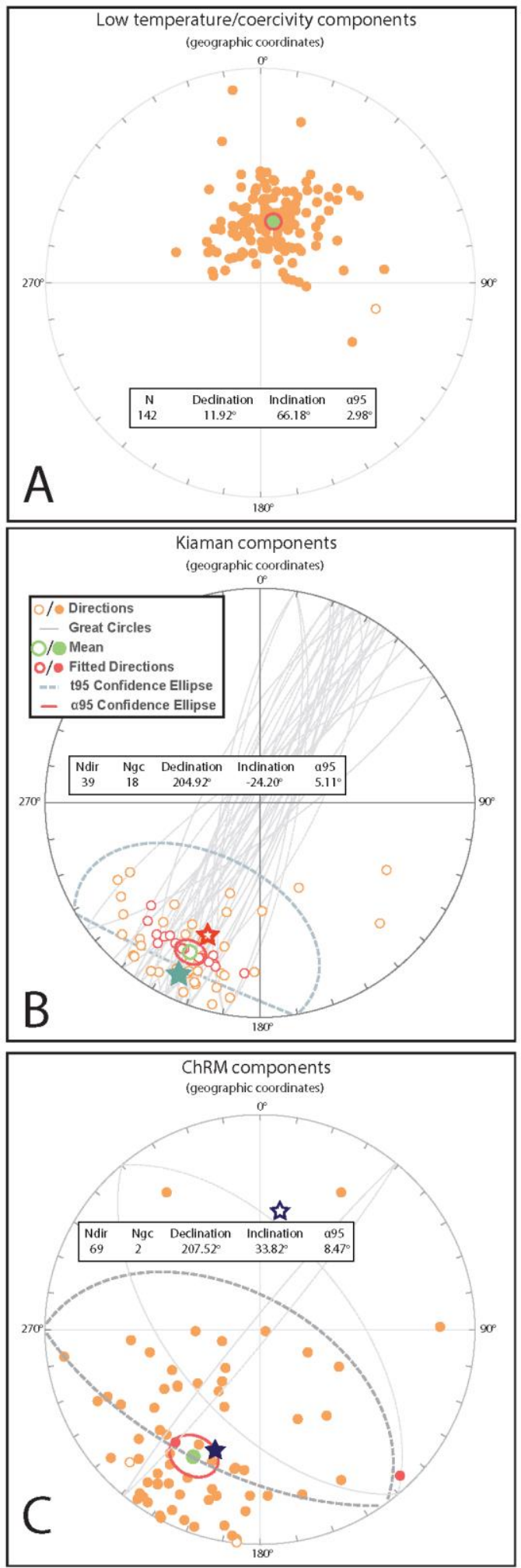

Fig. 8 - Equal area plots of interpreted directions. A. Interpreted low temperature/low coercivity components. B. Interpreted reverse polarity components with expected directions based on the Eurasian APWP of Torsvik et al. (2012). The red star represents the expected direction at $260 \mathrm{Ma}$ (Permian), the turquoise star is the expected direction at $320 \mathrm{Ma}$ (Carboniferous) C. Interpreted characteristic remanent magnetisation (ChRM) components, with blue star marking the direction from Zwing and Bachtadse (2000). 


\subsection{Poland}

\subsubsection{Thermomagnetic and susceptibility versus temperature runs}

As all of the samples have extremely weak magnetisations (tens to hundreds of microamperes per metre), thermomagnetic runs using a Curie balance and Variable Field Translation Balance (VFTB) measurements yielded no useful results. Kappabridge runs show an increase of susceptibility up to $\sim 300^{\circ} \mathrm{C}$, after which the susceptibility rises more sharply up to around $420^{\circ} \mathrm{C}$ (Fig. 9). Subsequently, susceptibility starts to decrease until around $550^{\circ} \mathrm{C}$, likely indicating the presence of low Ti-titanomagnetite, with specimens generally showing reversible behaviour.

IRM acquisition curves show mixtures of a low coercivity magnetite phase and a high coercivity (>300 mT) hematite phase (see Fig. 10), divisible into two groups. The first group, which includes the majority of curves, is dominated by the low coercivity phase (e.g. Fig. 10A, 10B) and shows virtually no sign of a high coercivity phase between 100 and $400 \mathrm{mT}$. The second group shows a small contribution from the low coercivity phase (Fig. 10C), and does not reach saturation at the maximum field of $600 \mathrm{mT}$ (Fig. 10D). In contrast to range of saturation, curves of susceptibility versus temperature are fully dominated by the magnetite phase in both groups (e.g. Fig. $10 \mathrm{~A}$ vs Fig. $10 \mathrm{C}$ ). These show only one Curie temperature $<580^{\circ} \mathrm{C}$.
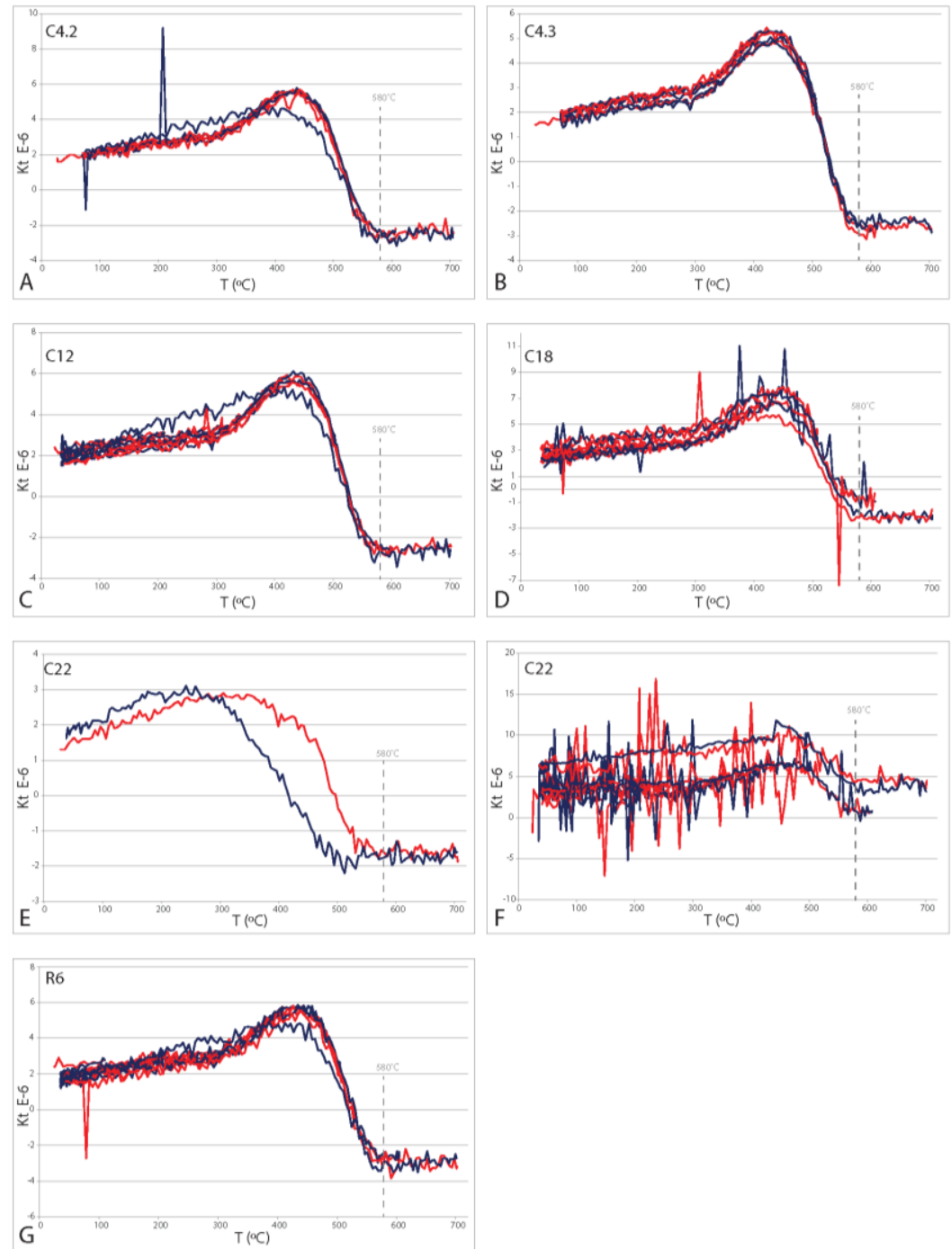

Fig. 9 - Kappabridge susceptibility versus temperature runs of five samples of limestones from the Czatkowice quarry, and one from the Racławka section. All runs are multi-segment runs, with the exception of sample C22 (9E). The Curie temperature of magnetite $\left(580^{\circ} \mathrm{C}\right)$ is indicated with a grey dashed line. 

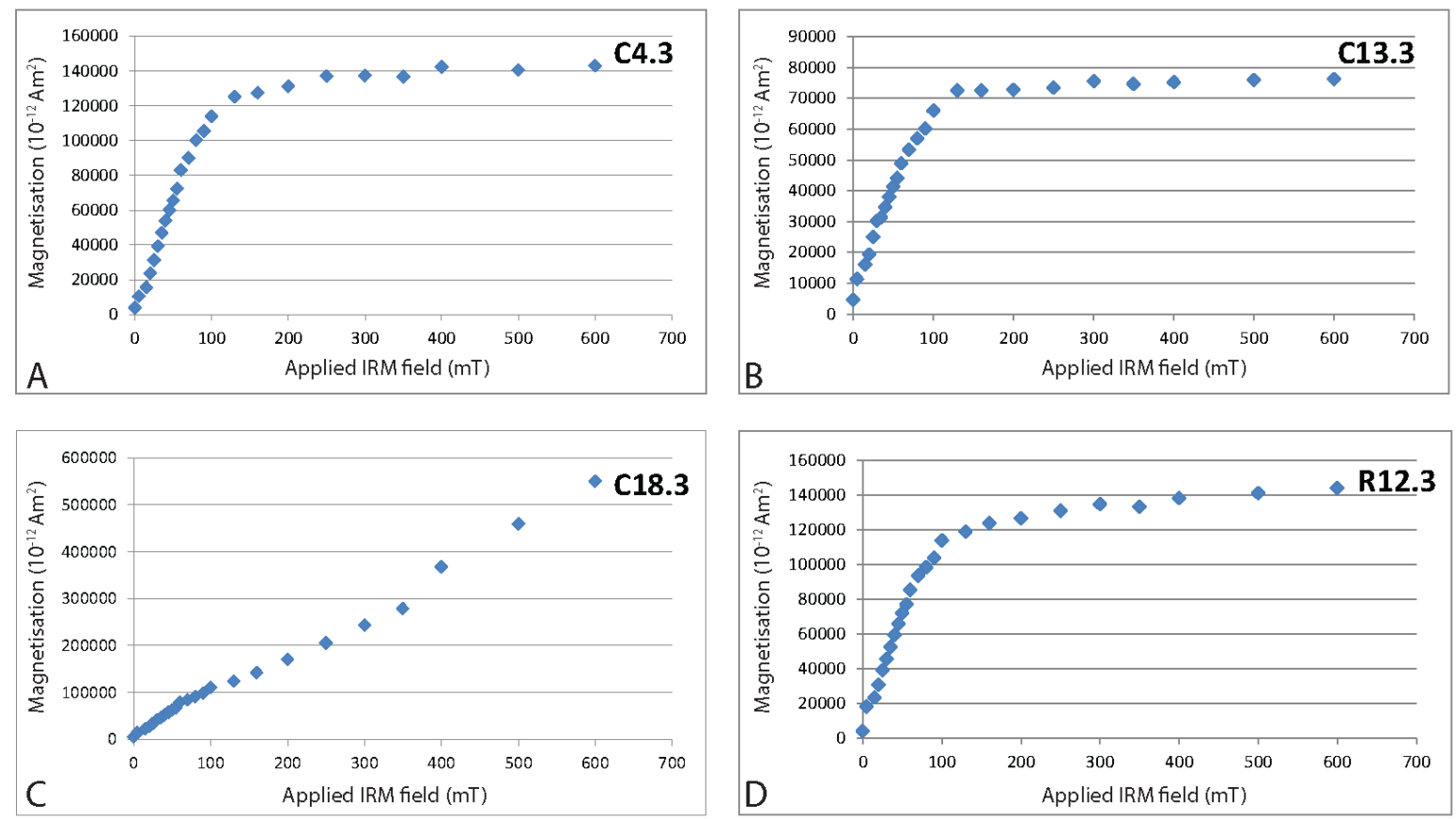

Fig. 10 - Representative examples of isothermal remanent magnetisation runs of samples from Poland, three from the Czatkowice quarry and one from the Racławka section.

\subsubsection{Directions}

Three components are observed (Fig. 11), which we interpret as representatives of a modern geomagnetic field, a Kiaman field and a Devonian field, corresponding to LT, MT and high temperature/coercivity (HT) components. Thermal demagnetisation was generally successful up to $300^{\circ} \mathrm{C}$; at higher temperatures, uncertainties on the measurements became very large (>20\%). Samples show low NRM intensities, on the order of tens to hundreds of microamperes per meter (see Fig. 4). Some samples (e.g. R3, supplementary file S3) show intensities of less than $5 \mu \mathrm{A} / \mathrm{m}$ and uncertainties on measurements of these samples are often more than $100 \%$. In some cases, samples show a pervasive magnetisation that resembles a modern field (Fig. 11A), or a Kiaman field (Fig. 11B). The best specimens show three components (Fig. 11C-H), which we interpret to represent a recent field, a Kiaman field, and a primary Devonian magnetisation, respectively. Demagnetisation behaviour shows overlapping components, indicated by demagnetisation along great-circle paths (e.g. C21.2, Fig. 11F, C20.1, Fig. 11H). One sample (R8.3, supplementary file S3) shows a very strong magnetisation ( 500 times stronger than other samples) and demagnetises in a straight line towards the origin of the Zijderveld diagram. We interpret this behaviour as remagnetisation, possibly due to a lightning strike.

The LT component is typically demagnetised by about $175^{\circ} \mathrm{C}$ or $16 \mathrm{mT}$ (Fig. $12 \mathrm{~A}$ ), and in some samples, this component is absent. At higher demagnetisation steps, 58 specimens show a southerly and up-directed component, interpreted as a Kiaman (or Permian-Carboniferous Reverse Superchron; PCRS) component (see Fig. 12B and 12C). In 68 specimens, no ChRM could be resolved. It remains unclear whether the Kiaman direction was acquired pre-tilting or post-tilting. Kiaman directions (TC) are dec $=187.7^{\circ}$, inc $=-27.2^{\circ}, \alpha 95=$ $5.3^{\circ}$, while Kiaman (NOTC) are dec $=199.5^{\circ}$, inc $=-17.9^{\circ}, \alpha 95=5.4^{\circ}$. The apparent polar wander path (APWP) of Torsvik et al. (2012) predicts directions for the Kiaman (or PCRS), which lasted roughly from 320-260 Ma, of dec $\approx 216^{\circ} \pm 4^{\circ}\left(320 \mathrm{Ma}\right.$ ) to dec $\approx 208^{\circ} \pm 3^{\circ}\left(260 \mathrm{Ma}\right.$ ) and inc $\approx 4^{\circ} \pm 10^{\circ}(320 \mathrm{Ma})$ to inc $\approx-39^{\circ} \pm 4^{\circ}(260 \mathrm{Ma})$. Our directions fit with Kiaman inclinations, but declinations are more southerly than expected, which could be related to local rotation of the Moravia-Silesia block. A post-Kiaman remagnetisation would not fit with the directions that we obtained. 

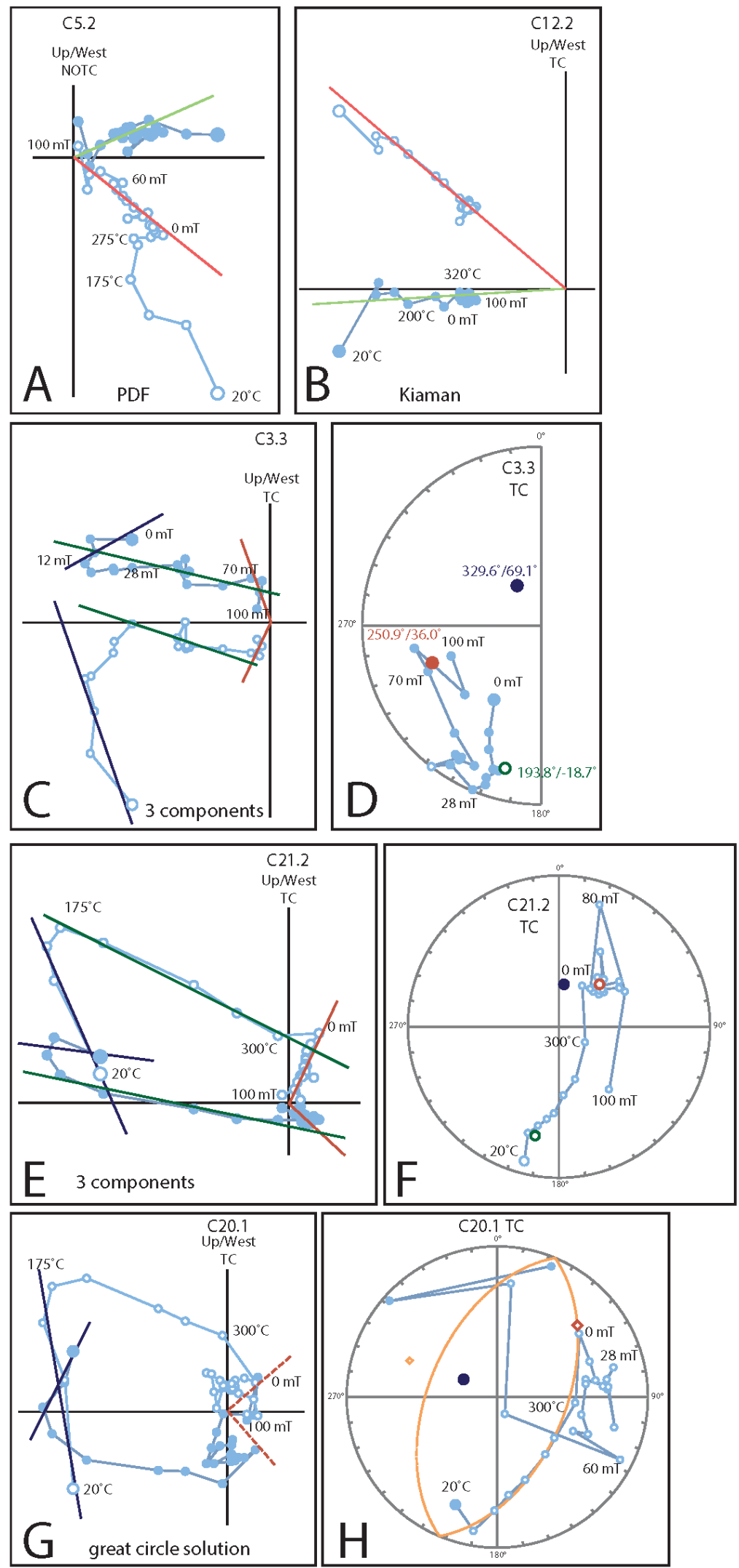

Fig. 11 - Representative examples of Zijderveld diagrams and equal area projections of samples from Poland. Legend is the same as Fig. 7. A. Sample showing a pervasive overprint that resembles the present day field (PDF). B. Sample showing a pervasive overprint that resembles a Kiaman direction. C. Sample C3.3 showing three components. D. Sample C3.3 with three interpreted components in an equal area plot. E. Sample C21.2 showing three components. F. Sample C21.2 with three interpreted components in an equal area plot. G. Zijderveld diagram of sample C20.1 showing demagnetisation along a great-circle path. H. Sample C20.1 and the interpreted great-circle and solution. 

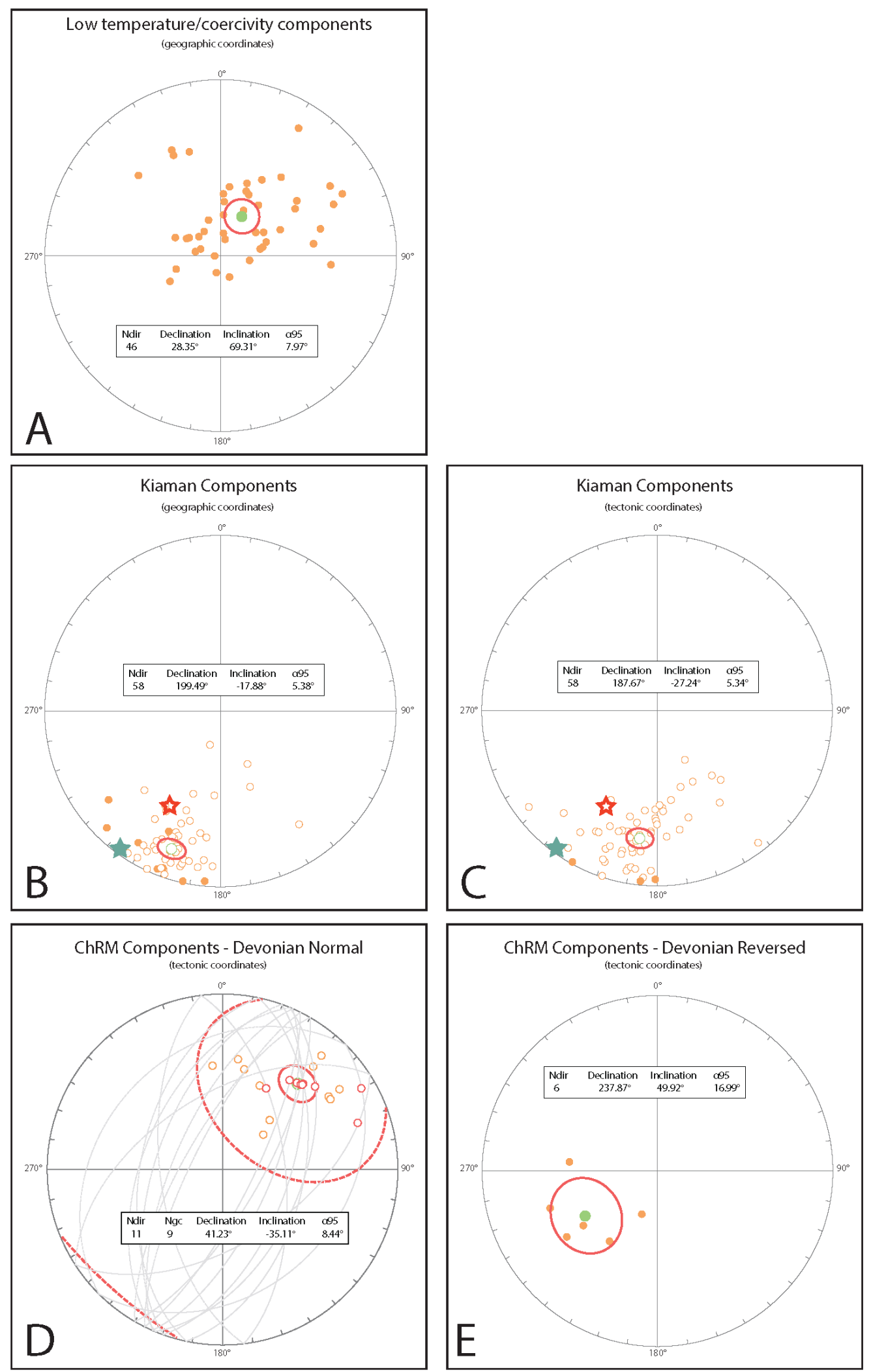

Fig. 12 - Equal area plots of interpreted directions of Polish samples. Legend is the same as Fig. 8. A. Low temperature/low coercivity components that resemble a modern field overprint. B. Components interpreted to represent overprinting during the Kiaman superchron without tectonic correction. C. Components interpreted to represent overprinting during the Kiaman superchron after tectonic correction. The red stars represent the expected direction at $260 \mathrm{Ma}$ (Permian); the turquoise stars the expected direction at $320 \mathrm{Ma}$ (Carboniferous). D. Characteristic remanent magnetisations and great circles that we interpreted as representative of Devonian normal polarity. E. Characteristic remanent magnetisations that we interpreted as representative of Devonian reverse polarity. 
A total of 26 specimens show dual polarity ChRM components, interpreted as Devonian normal (Fig. $11 \mathrm{E}-\mathrm{H}$ ) and reverse polarities (Fig. 11 C-D). Directions representing the Devonian normal polarity are much better resolved than Devonian reverse polarity. Many samples show clear great circle paths towards normal Devonian polarities only. This can be explained by partial component overlap between the normal ChRM and Kiaman component, which will give much longer great-circle paths than reverse ChRM and Kiaman. Samples that represent Devonian normal polarities give an average direction of dec $=41.2^{\circ}$, inc $=-35.1^{\circ}, \alpha_{95}=8.4^{\circ}$, while likely Devonian reverse polarities average to $\mathrm{dec}=237.9^{\circ}$, inc $=49.9^{\circ}, \alpha_{95}=17.0^{\circ}$ (see Fig. $12 \mathrm{D}-\mathrm{E}$ ). These directions correspond to poles with lat $=11.5^{\circ}$ and long $=160.3^{\circ}$ (normal) and lat $=-5.7^{\circ}$, long $=152.6^{\circ}$ (Devonian reversed converted to normal polarity; Table 1). Although the mean normal (converted) and reversed directions overlap within error (see Fig. 13), a reversal test using a bootstrap common true mean direction (CTMD) test (Tauxe, 2010) in paleomagnetism.org (Koymans et al., 2020) is negative.

\begin{tabular}{|l|l|l|l|r|r|r|r|r|r|r|r|}
\hline Site name & Lat & Long & Component & Dec Inc & & to N dec to N inc & & VGPlat & VGPlong \\
\hline Blankenheim & $50.44 \mathrm{~N}$ & $6.64 \mathrm{E}$ & Kiaman notc & 204.92 & -24.2 & & 24.92 & 24.2 & & 47.1 & 149.49 \\
& & & ChRM Drev? & 207.52 & 33.82 & & 27.52 & -33.82 & & 16.9 & 159.39 \\
\hline Poland & \multirow{2}{*}{$50.16 \mathrm{~N}$} & $19.64 \mathrm{E}$ & Kiaman notc & 187.67 & -27.24 & & 7.67 & 27.24 & & 53.73 & 187.02 \\
& & & ChRM Dnor & 41.23 & -35.11 & & 41.23 & -35.11 & & 11.53 & 160.25 \\
& & & ChRM Drev & 237.87 & 49.92 & & 57.87 & -49.92 & & -5.7 & 152.62 \\
\hline Canada & $65.18 \mathrm{~N}$ & $126.22 \mathrm{~W}$ & Kiaman notc & 115.71 & -36.55 & & 295.71 & 36.55 & & 29.09 & 128.97 \\
\hline
\end{tabular}

Table 1 - Average directions and corresponding poles.

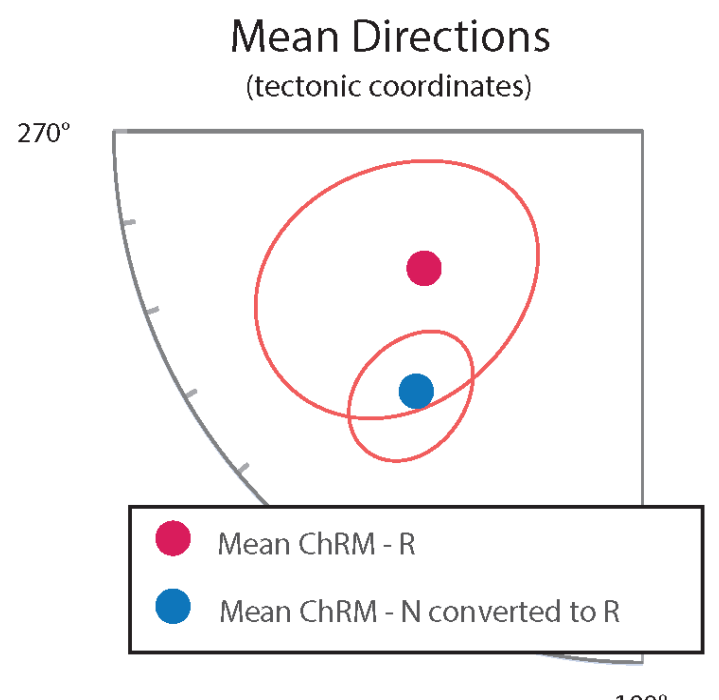

$180^{\circ}$

Fig. 13 - Averaged normal and reverse ChRM directions converted to the same hemisphere show overlap of directions, indicating that two populations of directions are somewhat antipodal.

\subsubsection{Polarity interpretation}

The lower part of both the Czatkowice and Racławka sections gave mostly Kiaman overprints, and ChRMs could be interpreted for only a few samples, which gave directions that possibly represent Devonian reversed polarities (See Fig. 14). From around 22-26 metres, two samples show normal polarities. Above this, there is one reversed sample (two successful specimens). The top of the section shows convincingly normal polarities, and these samples display indistinguishable rock magnetic properties from any others. This part of the section typically shows demagnetisation great-circle trends ending in a well-defined direction.

The Racławka section is correlated to the Czatkowice section based on biostratigraphy and lithostratigraphy. The tops of both sections show a very strong similarity in demagnetisation diagrams, with samples of both sections progressing along similar great-circles and ending in similar directions (see Fig. $11 \mathrm{E}-\mathrm{H}$ and supplementary file S3). The uppermost normal of the Czatkowice quarry thus corresponds to the upper part of 
the Racławka section. The available tie point for the Czatkowice quarry is the suspected position of the Devonian-Carboniferous boundary just above sample C19, which correlates to the Racławka section between samples R10 and R11 (thin dashed line in Fig. 14). This would mean that the Devonian-Carboniferous boundary corresponds to a normal polarity interval.

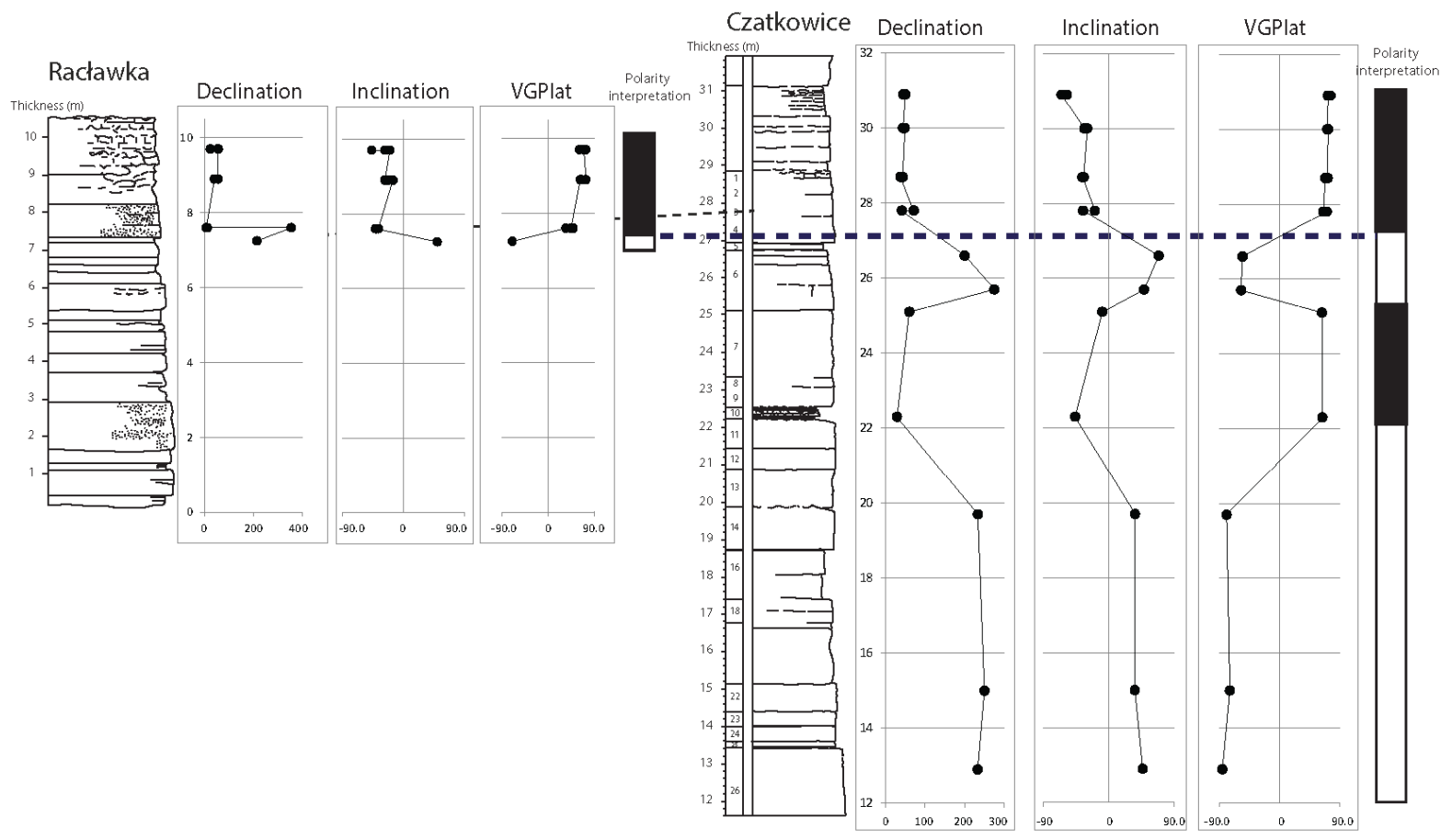

Fig. 14 - Magnetostratigraphic interpretation alongside lithological logs of the Racławka and Czatkowice sections and correlation between the sections.

\subsection{Canada}

\subsubsection{Susceptibility versus temperature changes}

Specimens show an increase of susceptibility up to $\sim 400^{\circ} \mathrm{C}$, after which susceptibility decreases (Fig. 15). Specimen NW16.2 (Fig. 15A) shows a decrease until $580^{\circ} \mathrm{C}$, indicating the presence of magnetite. Unlike the samples from Germany, a clear Hopkinson-like peak is not observed. Specimen NW21.2 (Fig. 15B) shows a decrease until around $600^{\circ} \mathrm{C}$ which could indicate minor hematite. At the end of the experiment, samples have roughly the same susceptibility as at the start and samples generally show reversible behaviour.

\subsubsection{Directions}

Almost all specimens show NRM intensities on the order of tens to hundreds of microamperes per meter. Some specimens show higher intensities of up to $1200 \mu \mathrm{A} / \mathrm{m}$, which are generally found in the top parts of the section where there is more variability in initial NRM intensity (see Fig. 5). Although specimens display a wide range of behaviours, there seem to be no differences in thermal versus alternating field demagnetisation. Sister specimens rarely behave the same. Most specimens show only a very small LT component, which is generally removed around $175^{\circ} \mathrm{C}$ or $10 \mathrm{mT}$ (see Fig. $16 \mathrm{~A}$ ), but some specimens are dominated by this component (see Fig. 16B and $16 \mathrm{C}$ ). This component resembles a modern field; with inclinations of around $80^{\circ}$ (expected inclination for a modern field is $77^{\circ}$ ). A large proportion of the samples ( 37 specimens) show an ESE, upward-directed (reverse polarity) magnetisation expected for a Carboniferous ( $320 \mathrm{Ma}$ ) Kiaman magnetisation (using the North American APWP from Torsvik et al., (2012); Fig. 16D-F). HT components observed in the samples do not cluster, but show a random spread (see Fig. 16G-J). Equal area plots of all 
interpreted components are shown in Figure 17. Clustering is also poor in specimen coordinates (see Fig. 17E), indicating that these HT components are unlikely to reflect a measurement artefact.

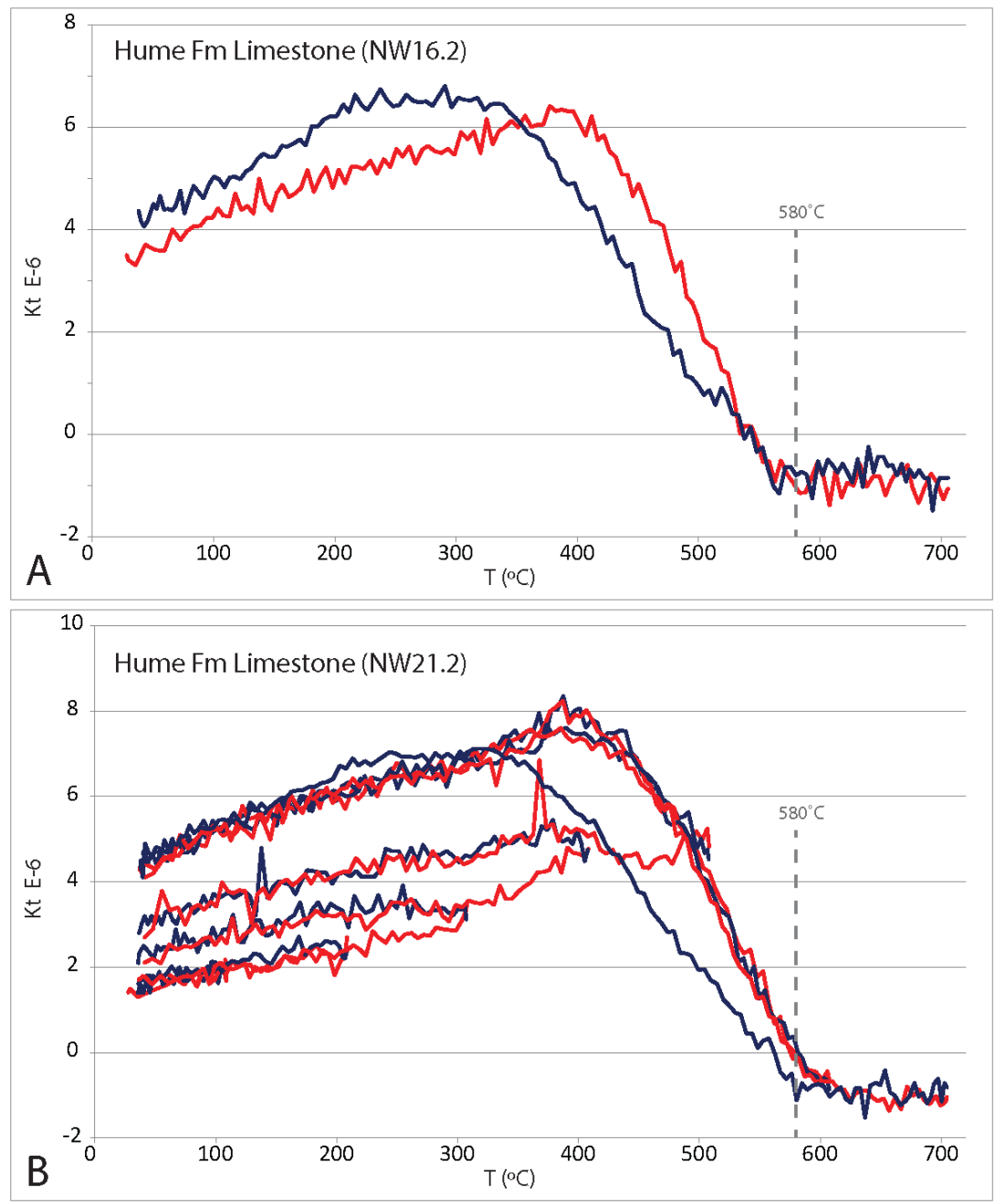

Fig. 15 - Kappabridge susceptibility versus temperature runs of samples of the Hume Formation. The Curie temperature of magnetite $\left(580^{\circ} \mathrm{C}\right)$ is indicated with a grey dashed line. 

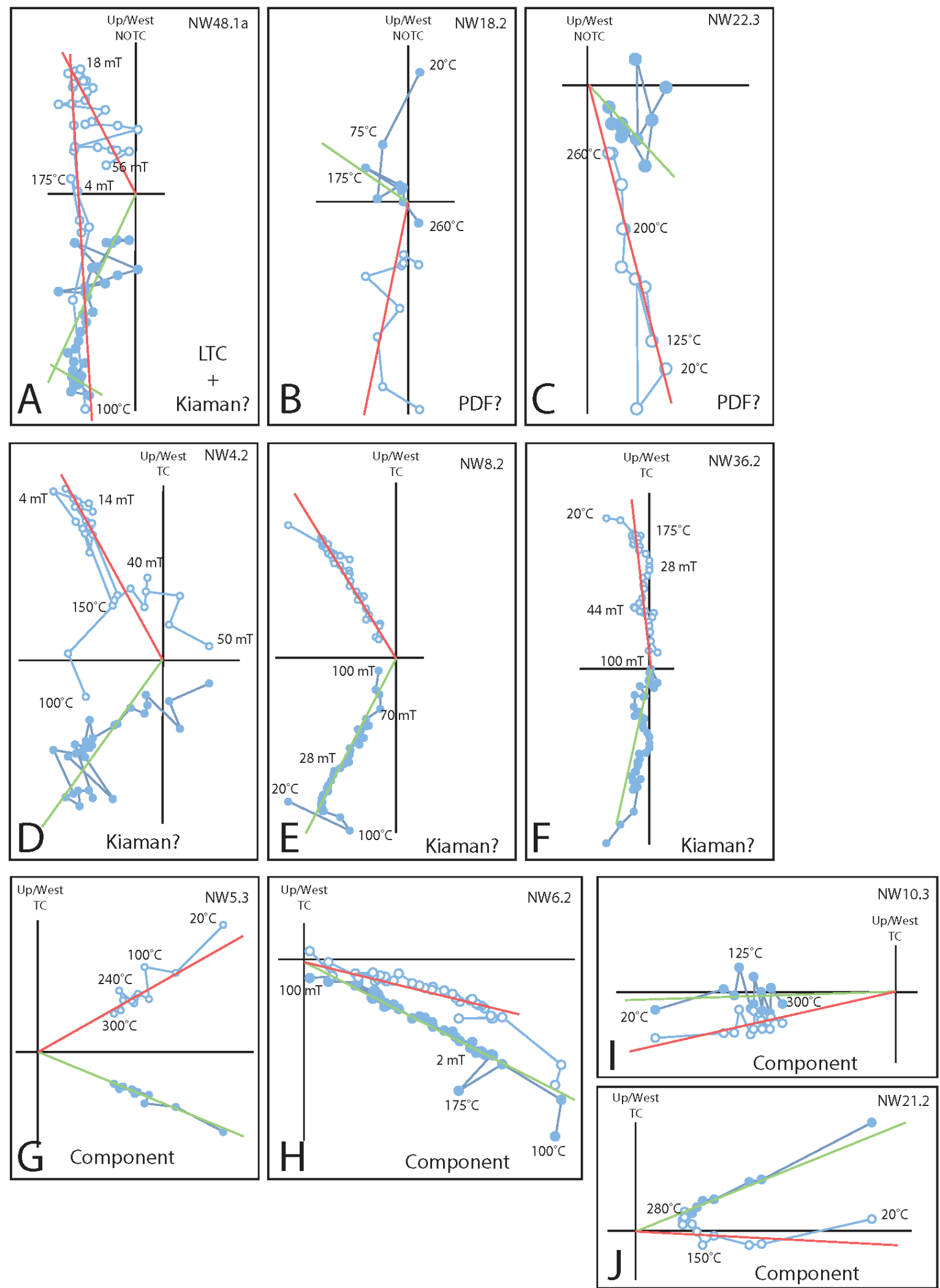

Fig. 16- Representative Zijderveld diagrams for samples from Canada. Legend is the same as Fig. 7. A. Sample shows a low temperature component and a component that we interpret to represent a Kiaman direction. B. and C. Samples showing a pervasive overprint that resembles a modern field direction. D - F. Samples showing a pervasive overprint that resembles a Kiaman direction. G-J. Samples showing clear demagnetisation towards the origin of the Zijderveld diagrams, but directions are extremely scattered. 

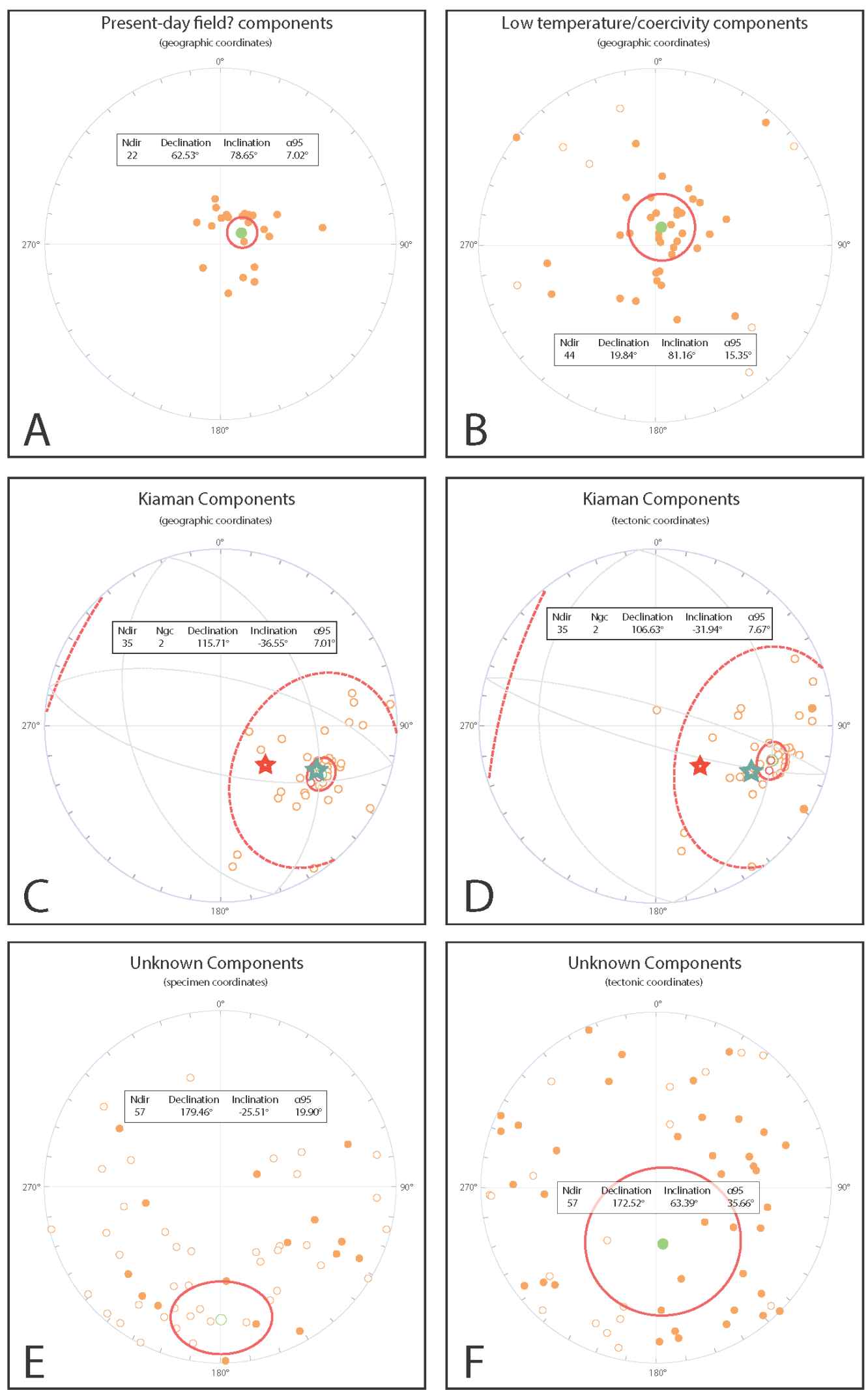

Fig. 17 - Equal area plots of the interpreted directions of samples from Canada. Legend is the same as Fig. 8. A. Directions that somewhat resemble a modern field. B. Low temperature/low coercivity components mostly resemble a modern field, albeit with large scatter. C. Components that resemble a Kiaman direction (without tectonic correction). D. Components that resemble a Kiaman direction (after tectonic correction). The red stars represent the expected direction at $260 \mathrm{Ma}$ (Permian); the turquoise stars the expected direction at $320 \mathrm{Ma}$ (Carboniferous). E. Unknown components plotted in specimen coordinates. F. Unknown components plotted after tectonic correction. 


\section{Discussion of new results}

\subsection{Germany}

It is unclear what magnetostratigraphic studies Becker et al. (2020) used in their polarity pattern in the GTS2020. The polarity is denoted as normal for the early Eifelian in GTS2020, and unknown for the late Eifelian. The Blankenheim section covers part of the late Eifelian. The directions that we interpret from our samples could indicate a Devonian reverse polarity that is similar to the Devonian direction of Zwing and Bachtadse (2000). We find an average direction of $d e c=207.6^{\circ}$, inc $=34.4^{\circ}, \alpha_{95}=8.4^{\circ}$ (direction reported by Zwing and Bachtadse (2000) is dec $=198^{\circ}$, inc $\left.=40^{\circ}, \alpha_{95}=4.9^{\circ}\right)$. However, due to the absence of field tests, we refrain from interpreting our data as primary Devonian directions. We cannot exclude the possibility that this direction is a combination of a Kiaman direction and a modern field direction.

\subsubsection{Age constraints}

Although the base of the Tortodus kockelianus Zone is missing, and it is thus difficult to estimate how much time there is in the section, we can still make an estimate of the maximum amount of time in the section. The Tortodus kockelianus Zone has a duration of around $2 \mathrm{Myr}$ and encompasses the whole Junkerberg Fm. The Blankenheim section, which represents only a portion of the Junkerberg Fm, likely corresponds to at most a few hundred kyr. De Vleeschouwer et al. (2018) describe a sedimentation rate of $3.2 \mathrm{~cm} / \mathrm{kyr}$ for the Wetteldorf section, which contains the Emsian-Eifelian boundary and is located $\sim 40 \mathrm{~km}$ from the Blankenheim section. Based on the similar lithology, we estimate that sedimentation rates in the Blankenheim section are of the same order, which would mean that the Blankenheim section covers around $250 \mathrm{kyr}$.

\subsection{Poland}

Because of the limited upper Devonian in the sections in Poland, it is not possible to make a comparison with the polarity pattern of the study of Hansma et al. (2015), which covered the Frasnian-Famennian boundary (see Fig. 1). The directions we find in our Polish samples represent two polarities, and results are consistent between the two measured sections, which we can confidently correlate based on the magnetic polarity pattern and biostratigraphy (thick dashed line in Fig. 14). Liu et al. (1991), however, find a reverse magnetozone with overlying normal magnetozone just above the Devonian-Carboniferous boundary, while we find a similar reversal just below the inferred Devonian-Carboniferous boundary. Kolesov (2007) finds a similar R-N magnetozone boundary in both the Kamenka section in NE Russia and the Kozhim section in the northern Urals, rather closer to the inferred, Devonian-Carboniferous boundary like in our data (Kolesov 2005). These differences are likely explained by imprecision in placement of the Devonian-Carboniferous boundary in the Polish sections.

\subsubsection{Age constraints}

The Devonian-Carboniferous succession in the Czatkowice Quarry and Racławka Valley was described by Paszkowski (in Dvorák et al., 1995; compare to Łaptaś, 1982 and Narkiewicz and Racki, 1984). He divided the lower part of the succession into 6 formations (from base to top): the Dubie Formation with the Góra Żarska Member at its top, Racławka Formation, Szklary Formation, Paczółtowice Formation, Pstrągarnia Formation and Przy Granicy Quarry Formation. The total thickness of this part is about $450 \mathrm{~m}$. Paszkowski (1995) originally assumed an early to middle Tournaisian age of the Dubie and Racławka formations. According to Wolniewicz (2009), the assemblage of foraminifera found in the Góra Żarska Member of the Dubie Formation indicate the Famennian Quasiendothyra communis-Quasiendothyra regularis foraminiferal Zone, which corresponds to the Upper Palmatolepis marginifera - Upper Palmatolepis expansa conodont zones (Wójcik, 2012). A similar assemblage of foraminifera, with Quasiendothyra communis communis and Eoendothyra regularis and no representatives of $Q$. kobeitusana and Carboniferous tournayellids have been found in the 
upper part of the Racławka Formation within the studied interval during fieldwork in 2016. On the other hand, the early Tournaisian age of the Szklary Formation is suggested based on the presence of a foraminiferal assemblage with Earlandia elegans and Eochernyshinella crassitheca, which corresponds to the MFZ2 Foraminiferal Zone of the Belgium and Siphonodella belkai conodont Zone in the Ural region (Bąk et al., 2014; compare to Poty et al., 2003). The Carboniferous (Tournaisian) age was proved also for the Przy Granicy Formation based on conodonts (Appelt, 1998; compare to Gromczakiewicz-Łomnicka, 1974).

The exact position of the Devonian-Carboniferous boundary in the Czatkowice Quarry, as well as in the Racławka Valley is still uncertain. However, analogous to the Kraków platform, the upper Famennian cyclic sequences with oolites and bahamite grainstones were described from e.g. Montagne Noire (La Serre section; e.g. Feist et al., 2000) and Aachen-Velbert area sections (Laupen subformation of Hastière Formation; Hance and Poty, 2006). The Hance section contains the same succession of characteristic lithofacies, calcretised and stylolitised subaerial exposure surfaces, transgressive lags and bentonite layers, which are covered by up to 2 $\mathrm{m}$ thick oolitic-bahamitic grainstone bed (bed no 159 in the Anseremme section) corresponding to the D/C boundary (Hance and Poty, 2006). The precise lithostratigraphic correlation of the mentioned sections, as well as identification of the stage boundary in the Czatkowice quarry needs further investigation.

\subsection{Canada}

We observe three components in the samples from Canada, one resembling a modern field, one resembling a Carboniferous reverse polarity, and one that is extremely scattered and may have no geological significance (see Fig. 17). We thus cannot make an interpretation concerning Devonian directions or polarities from the Canadian samples.

\subsubsection{Age constraints}

The upper $61 \mathrm{~m}$ of the Hume Formation at Prohibition Creek mainly consist of bioclastic mudstone and wackestone with birds-eye fenestral structures and rare macrofossils, and wackestone/packstone in the uppermost $3 \mathrm{~m}$ and lowermost $10 \mathrm{~m}$ of the studied interval (Kabanov et al., 2019). Most archival and recent samples taken for conodont biostratigraphy in this part of the Hume were barren, except for a few samples in the wackestone/packstone beds. Faunas are dominated by Icriodid taxa in the lowermost beds and by Polygnathid taxa in the uppermost beds. However, the index taxa for the upper Eifelian part of standard conodont zonation, Tortodus kockelianus and Polygnathus ensensis are not present in the samples. Visual correlation with the Hume type section, and several other sections representing the Hume Formation in the northern Mackenzie Mountain front (Gouwy, unpublished data; Gouwy and Uyeno, 2018), allows projection of the standard conodont zonation onto the Prohibition Creek section, based on the faunas identified in the different sections. For the T. kockelianus Zone, Polygnathus curtigladius, the local auxiliary taxon used to indicate the base of the zone (Uyeno et al., 2017), is projected onto the Prohibition Creek section at $90 \mathrm{~m}$ below the top of the Hume Formation. The kockelianus Zone in the studied interval covers thus roughly two thirds of the entire kockelianus Zone in the section. The index taxon $P$. ensensis has a delayed first appearance in the lowermost part of the Hare Indian Formation in the Mackenzie Mountains and Mackenzie Valley area. The base of the $P$. ensensis Zone is indicated by the appearance of the brachiopod Eliorhynchus castanea, index for the castanea brachiopod Zone (Pedder, 2017) whose base coincides with the base of the $P$. ensensis Zone, in the Hume type section and projected at $2.5 \mathrm{~m}$ below the top of the Hume Formation in the studied section. Based on the conodont zones identified in the section and the estimated 2 Myr duration of the kockelianus Zone (Becker et al., 2020), the studied interval represents roughly 1.3 Myr.

\subsection{Summary of new results}

Our new results are of varying quality. The results from the sections that we have measured in Germany and Canada provide problematic paleomagnetic results. The samples from the Blankenheim section show either 
only a Devonian reverse polarity (see Fig. 9), or represent a direction that is a mixture between the Kiaman field and a modern field, but we cannot presently distinguish between the two, due to the lack of field tests. Samples from Canada show three types of directions: components likely resembling a modern field direction, components resembling a Carboniferous Kiaman direction, and unknown components that show extremely large scatter (see Fig. 12). The Polish sections, however, seem to produce reliable results.

Comparing our results from Poland with another study from the Holy Cross Mountains in Poland, we see that there are many other poles from this region. Grabowski and Nawrocki (2001) find 7 groups of data, of which 4 are located on a great-circle. The authors discuss in detail how their data might be explained, but do not provide an all-encompassing solution, and conclude that a definite tectonic interpretation is not possible. They discuss the necessities for some poles to be the result of remagnetisation, as they were derived from later dolomitisation and limestones with a high CAI. However, explaining all results would require large vertical-axis tectonic rotations that are not in agreement with structural observations in the area. Another option they discuss is strain modification of magnetic minerals, which is in disagreement with their AMS results. Our Devonian normal polarity average $\left(\mathrm{dec}=41.2^{\circ}\right.$, inc $\left.=-35.1^{\circ}\right)$ falls between two of their directions (denoted DO and JO) and lies along the great-circle that Grabowski \& Nawrocki describe (see Fig. 18). Our Devonian reverse polarity average $\left(\mathrm{dec}=237.9^{\circ}\right.$, inc $\left.=49.9^{\circ}\right)$ does not compare to any of their results. Thus, while we conclude that the new paleomagnetic directions obtained from our Polish sections probably represent reliable Devonian field directions, collectively, rocks from this area present a puzzling record of the magnetic field.

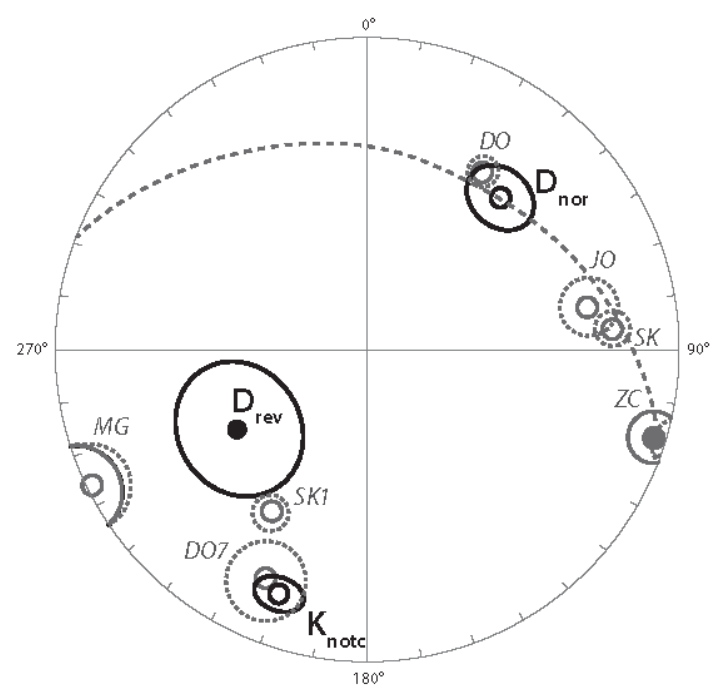

Fig. 18-Comparison of our newly acquired directions $D_{\text {nor }}$ (Devonian normal polarity average) and $D_{\text {rev }}$ (Devonian reverse polarity average) with paleomagnetic directions from Polish limestones from Grabowski and Nawrocki (2001).

One of the common observations from Devonian paleomagnetic results is that the rocks have suffered from widespread remagnetisation, mostly during the Kiaman reverse superchron (e.g. North America: Irving and Strong, 1985, 1984; Mac Niocaill and Smethurst, 1994; McCabe and Elmore, 1989; Belgium: Garza and Zijderveld, 1996; Zegers et al., 2003; Ukraine: Jeleńska et al., 2015; Smethurst and Khramov, 1992; Poland: Kadziałko-Hofmokl et al., 1999; Nawrocki, 1993; Algeria: Aïfa, 1993; Mauritania: Kent et al., 1984; Germany: Zwing and Bachtadse, 2000; Australia: Schmidt et al., 1986; Ireland: Pastor-Galán et al., 2015; Urals: Iosifidi and Khramov, 2013). However, one important question stands out: how can rocks obtain an overprint when the conditions for thermal overprinting are barely met? Königshof et al. (2016) provide detailed rock magnetic studies on samples of the Blankenheim section, and mention that thermally-related alteration appears to be very weak, based on thin-sections and preservation of fossils. Conodont alteration index values indicate that the succession in the Blankenheim section was subjected to maximum temperatures of around $55{ }^{\circ} \mathrm{C}$, which are unlikely to cause significant thermal-overprinting (e.g. Pullaiah et al., 1975). Furthermore, Königshof et al., (2016) argue that superparamagnetic grains, which they expect in remagnetised samples, are not very 
common. The grain size of the magnetite grains in the Blankenheim section is in favour of a detrital origin (Königshof et al., 2016). So while all the conditions for the probable preservation a primary Devonian paleomagnetic signal have been met, our directional results show a pervasive partial Kiaman overprint. In order to gain a broader insight into the Devonian geomagnetic field we turn to reviewing the global dataset of published paleomagnetic measurements.

\section{Review of Devonian paleomagnetic studies}

\subsection{Magnetostratigraphy of the Devonian}

Most of the global polarity time scale (GPTS) is based on marine magnetic anomalies that go back in time to the Middle Jurassic. A GPTS for the Early Jurassic and older will thus have to be derived from records obtained from outcrops. For the Triassic, a lot of progress has been made in the last few years (e.g. Kent et al., 2019; Maron et al., 2019). The Early Permian and Pennsylvanian are dominated by a predominantly reverse polarity (e.g. Hounslow and Balabanov, 2018), and the somewhat limited data for the Mississippian indicated mixed polarity (Hounslow, 2021). Constraining the GPTS and reversal frequency for the Devonian to Carboniferous is crucial for the understanding of the behaviour of Earth's magnetic field. The Earth's magnetic field is hypothesised to have a 'heartbeat', of varying average reversal frequency and intensity, with a periodicity of about 200 million years (e.g. Biggin et al., 2012). A strong magnetic field is generally associated with magnetic superchrons, such as the Cretaceous normal superchron (e.g. Tarduno et al., 2002). These are periods of millions of years in which the magnetic field is extremely stable and there are no (or very few) reversals of the magnetic poles of the earth. On the other hand, a weak field is commonly associated with many reversals, such as the mid-late Jurassic hyperactivity (e.g. Kulakov et al., 2019). These changes in the strength of the field and the reversal frequency are thought to be linked to heat flow across the core-mantle boundary, which may in turn be linked to supercontinent cycles and subduction flux (Hounslow et al., 2018). This 200 Myr periodicity hypothesis relies heavily on the behaviour of the magnetic field during the Devonian (420-360 Ma). The 'heartbeat' hypothesis predicts a weak field for this time, with a high reversal frequency.

Construction of a GPTS for the Paleozoic could provide a valuable tool for age determination. However, data as presented in the Geologic Time Scale for the Devonian require careful inspection. In Figure 1, we give an overview of the polarity patterns that were provided for the Devonian in the most recent versions of the geologic time scale (GTS; 2020, 2016, 2012 and 2004). For the newest version (Becker et al., 2020), the polarity pattern in the Devonian is taken from the 2012 version (Becker et al., 2012), with an added polarity pattern as obtained from the Canning Basin in Australia by Hansma et al. (2015). A slightly older version of the timescale (2016) shows conflicting polarity patterns around the Devonian-Carboniferous boundary. Ogg et al. (2016a), in their chapter on the Devonian, put the boundary in an interval of unknown polarity, while in the chapter on the Carboniferous, Ogg et al. (2016b) put the Devonian-Carboniferous in a reverse polarity interval. These inconsistencies are largely inherited from older versions of the timescale, as the patterns of Becker et al. (2012) differ from the patterns of Davydov et al. (2012). However, the biggest issue with the polarity patterns as presented in the timescale is that it is unclear what data they are based on. Clues to the origins of these polarity patterns are the names of some of the polarity intervals, such as 'Sayan hyperchron', 'Donetzian mixed polarity hyperchron', etc., which indicate that these geomagnetic polarity intervals likely have their ultimate origins in the Russian 'general stratigraphic scale' (Guzhikov, 2019; Khramov and Shkatova, 2000). In this scale it is unclear which parts of the polarity timescale have suffered from remagnetisation, and which data were included into the GPTS (see also the discussion on this in Guzhikov, 2019). The review of Carboniferous polarity by Hounslow (2021) has largely dispensed with these older uncertain datasets. As Figure 1 illustrates, the Russian Devonian timescales of Kolesov (2005) and Khramov and Shkatova (2000) are not similar at all to the GPTS to the timescales of 2004, 2012 and 2016. 
The only well-documented study of Devonian magnetostratigraphy is from Frasnian-Famennian (Late Devonian) carbonates in the Canning Basin in Australia (Hansma et al., 2015). All other studies that provide magnetic polarity patterns (e.g. Kolesov, 2007, 2005, 1984) do not show the data on which they are based, preventing the quality of the magnetostratigraphic data to be assessed. Sampling strategies for constructing a magnetostratigraphy are very different from paleopole type studies. Studies aimed at reconstruction of poles generally collect $\geq 5$ samples per site, with sites not normally evenly distributed through rock successions, whereas, for magnetostratigraphy sampling ideally consists of closely-spaced, evenly distributed samples with respect to stratigraphic height. The large magnetostratigraphic study by Hansma et al. (2015) used almost 900 samples, and was performed on rocks which were challenging due to weak magnetisations. Hansma et al. compared their data with previous studies on the same sections (Chen et al., 1995; Hurley and Van Der Voo, 1987), and reported that their new data clustered in the southwestern quadrant of the stereonet, in agreement with the poles of the previous studies. However, Hansma et al. applied a $45^{\circ}$ cut-off centred on the mean of the prior poles, which eliminated nearly half of their data points ( $45 \%$ of Oscar range data and $40 \%$ of Horse spring data). Applying this process, Hansma et al. reported a field that is moderately rapidly reversing (reversal frequency is on the same order as during the Paleogene, ca. 2 reversals per Myr) even when omitting magnetozones based on a single sample. However, the correlation of the magnetozones between their two time-equivalent sections is rather ambiguous and their untreated data is near randomly distributed on a sphere (see Fig. 19). Using the conglomerate test of Heslop and Roberts (2018), indicates that this is uniform distribution at $95 \%$ probability. Clearly, applying a $45^{\circ}$ cut-off on a near-uniform distribution of directions that are randomly ordered with respect to stratigraphic height will produce a conclusion of a rapidly reversing field. The creation of a robust magnetostratigraphy from these results is therefore in doubt, and we suggest that inclusion of the inferred magnetozones in any GPTS is unwise, unless better validated.
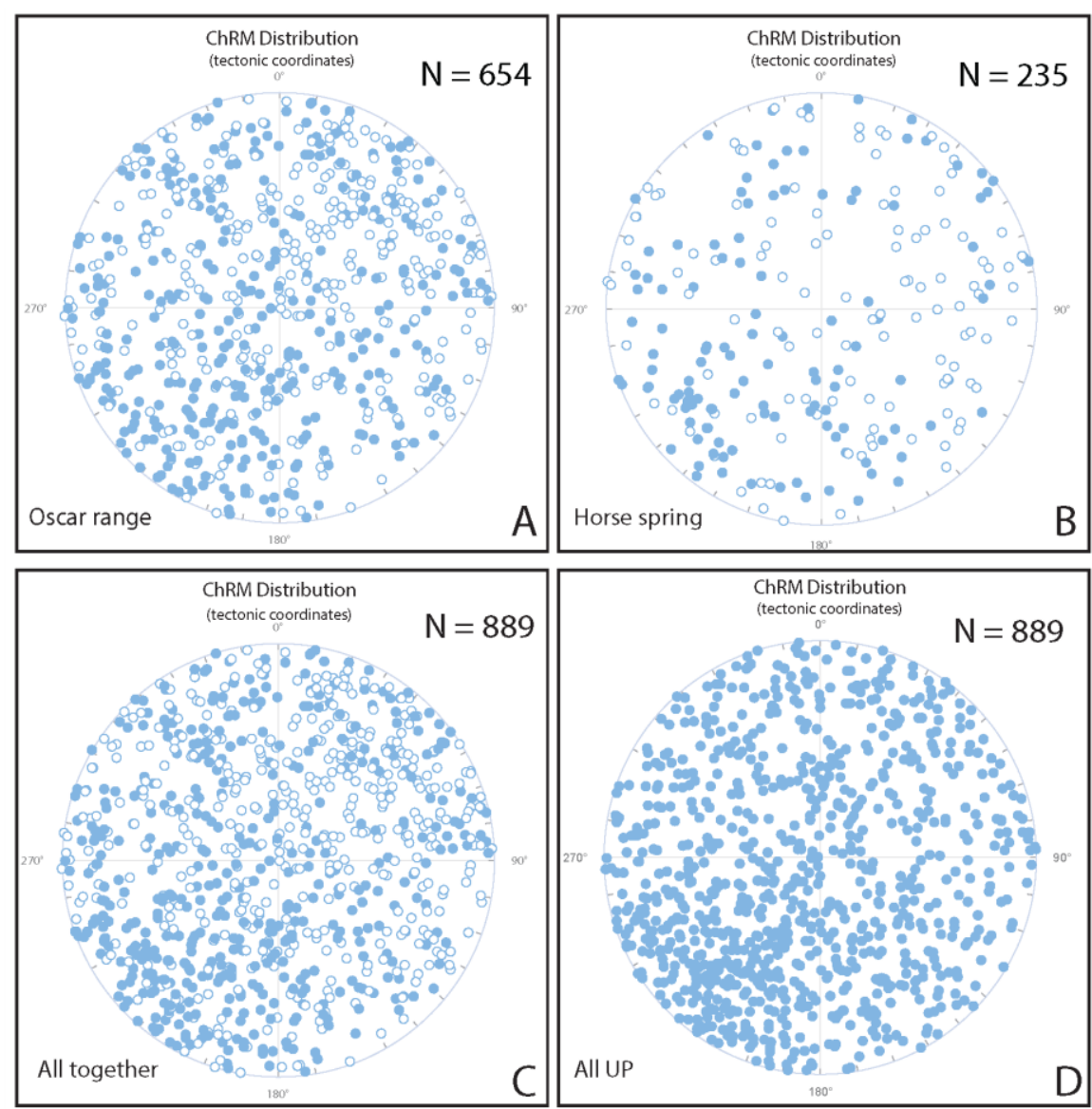

Fig. 19 -All data from the study of Hansma et al. (2015) on the Canning basin in Australia. A. All data from the Oscar Range. B. All data from Horse spring. C. All data from Oscar Range and Horse spring together. D. All data together converted to the same hemisphere. 


\subsection{Tectonic paleomagnetic studies of the Devonian}

Since the early days of paleomagnetic study, there has been a struggle for reconstruction of plate tectonics using paleopoles obtained from Devonian rocks (e.g. Livermore et al., 1985). Plate reconstructions based on paleomagnetism have been shown to be challenging to match with climate belts and lithologic indications of paleolatitude, notably with Russian gypsiferous sediments in the Late Devonian (Khramov, 1967; Witzke, 1990; Witzke and Heckel, 1988). Evans (2006) looked at the geographic distribution of evaporites, and surmised that Devonian-Ediacaran evaporites show an anomalous distribution compared to Cenozoic-Carboniferous evaporites when using paleopoles to infer paleolatitudes. For many plates, reliable Devonian poles are lacking. More than 40 years ago, Morel and Irving stated that reliable plate tectonic reconstructions can be made from the middle Carboniferous onwards, whereas for the Devonian, reconstructions are poorly constrained due to the scarcity of results (about 8 paleomagnetic results per $10 \mathrm{Myr}$, compared to 20 for Carboniferous and later times; Morel and Irving, 1978). Morel and Irving introduced two APW paths, based on the inclusion or exclusion of Australian data, based on a total number of 56 paleopoles. They show an X-path, which is relatively straight, and a Y-path, which has a large loop (see discussion in Vérard, 2004). The Y-path results in drift rates for plates that are $40-60 \mathrm{~cm} / \mathrm{yr}$, rates which have not been observed anywhere else (Vérard, 2004).

Cocks and Torsvik (2002) provide a review of paleopole data and fauna from 500-400 Ma and conclude that the reliability of paleopole data decreases into the Devonian with Torsvik et al., (2012) noting that data is truly scarce from the Middle Devonian to the Mississippian. Figure 20 shows the number of poles in the APWP of Torsvik et al. (2012), which highlights that there has been little progress in improving the scarcity of Devonian paleopole data since 1978. Cocks and Torsvik (2007) highlighted that between the Llandovery and latest Permian boundary, there are only two reliable poles for the reconstruction of Siberia and Baltica. One has an age of around $360 \mathrm{Ma}$, close to the Devonian-Carboniferous boundary, and the other one an age of $275 \mathrm{Ma}$, (late early Permian). Bachtadse and Briden (1990) indicate that the Devonian is the most problematic segment of the Gondwana APWP and Torsvik et al. (2012) show that data coverage is especially poor for Laurentia between 400-340 Ma and that paleopoles for 260-350 Ma and 390-380 Ma are interpolated. This interpolation results in the so-called 'Siluro-Devonian cusp' (Torsvik et al. 2012), which has been interpreted as an episode of extreme true polar wander (e.g. Piper, 2006; van der Voo, 1994). In short, there is an agreement that all plates suffer from a severe scarcity of high quality Devonian paleopole data.

In assessing the quality of paleopoles, a common approach is to classify the poles based on the reliability criteria of Van der Voo (1990), a widely accepted approach to filter-out older studies based on inadequate demagnetisation techniques. The Van der Voo criteria are used to quantitatively assess the quality of paleomagnetic poles, and for each of the $7 \mathrm{Q}$-criteria, the palaeopole gets 1 point. Commonly only poles that have a minimum value of $Q=3$ are taken into account for construction of apparent polar wander paths. The minimum criteria $(Q=3)$ state that the rocks must (1) have a well-determined age and presumption that the magnetisation is of the same age, (2) results are based on a sufficient number of samples and (3) the rocks were adequately demagnetised. Reliability can be further increased by field tests that constrain the age of magnetisation, structural controls are provided, reversals are observed, and there is no resemblance to paleopoles of a younger age. Algeo (1996) uses 35 poles obtained from Devonian rocks to assess polarity bias in the Devonian, with each of these passing a number of quality criteria of Van der Voo (1990). Similarly, Mac Niocaill and Smethurst (1994) use 11 poles for the reconstruction of the APWP of Laurentia. Torsvik et al. (2012) used 18 Devonian paleopoles for the construction of the APWP (see Fig. 20), with many having a high Qindex, up to the maximum of 7 using the Van der Voo (1990) criteria. As discussed below, however, problems still exist with Devonian paleopoles even if they have a high Q-index, indicating that scarcity of data has not been solved with modern studies. 


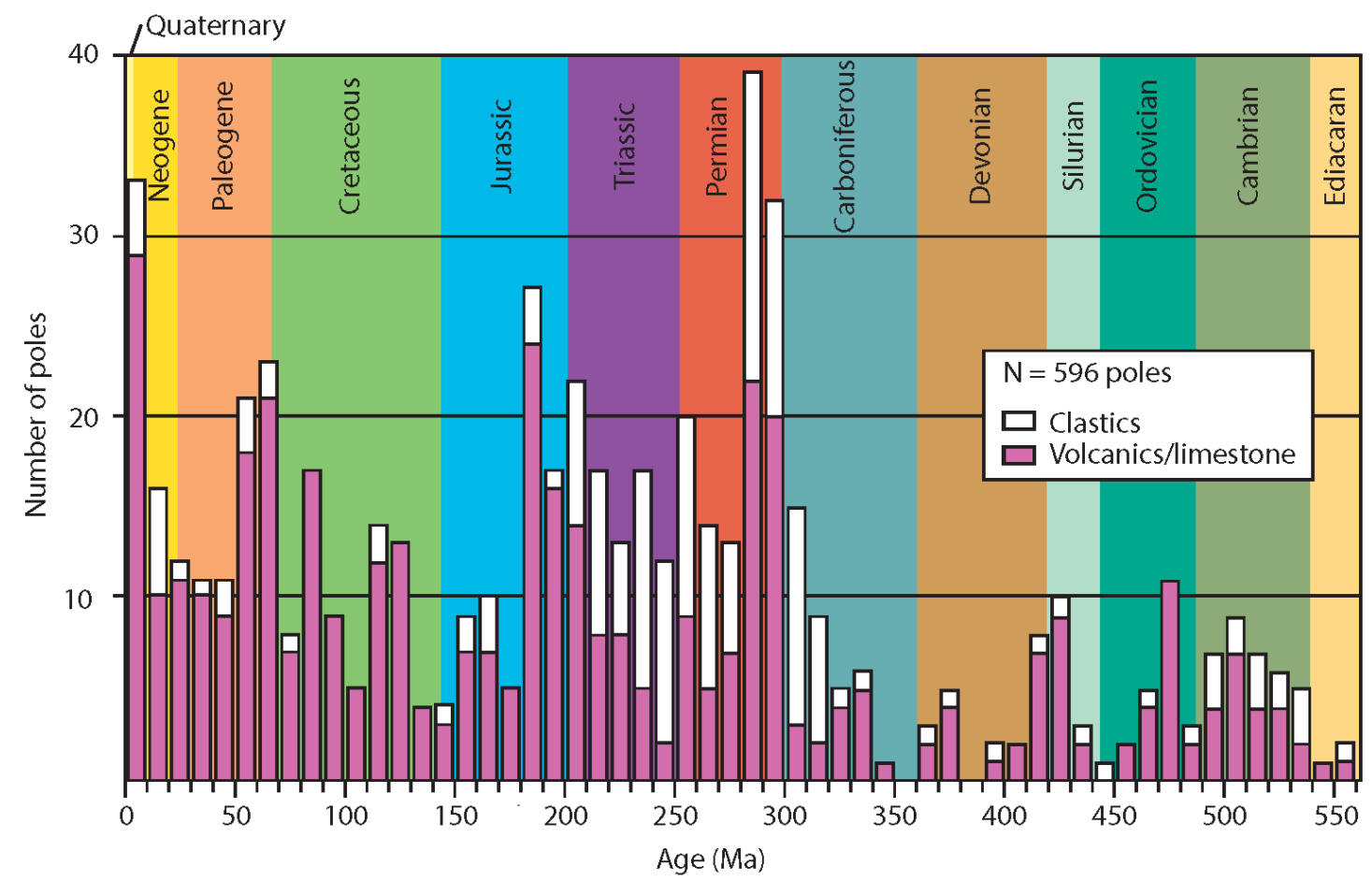

Fig. 20 -Number of poles in 10 Myr bins in the APWP of Torsvik et al. (2012) (modified after Torsvik et al., 2012), plotted on the Geologic Time Scale 2020 (Gradstein et al., 2020).

For the Australian part of East Gondwana, for example, Torsvik et al. (2012) include 4 poles. Three of these poles are from the Canning Basin and are obtained from equivalent formations (Chen et al., 1995; Hurley and Van Der Voo, 1987). The 4th pole is cited as 'E. Tohver, pers. comm. (2012)', and likely equates to the study of Hansma et al. (2015). Arguably, these 3 poles all form just one pole, as they were obtained on the same succession. That is, if they should be taken into account at all, as discussed previously for the Hansma et al. (2015) data. The Chen et al. (1993) paleopole for the Australian APWP cannot be reconciled with the data from Africa by Bachtadse and Briden (1991), while both of these studies are included in the APWP. Chen et al. solve this by stating that the GB pole from the study of Bachtadse and Briden (1991) is likely primary, while they regard the GC pole as a later remagnetisation. However, the GC pole of Bachtadse and Briden (1991) is included in the APWP. The only pole taken into account for the western Gondwana APWP is from the Bokkeveld Group in South Africa from the study of Bachtadse et al. (1987). However, Bachtadse and Briden (1990) do not consider data from Bokkeveld Group as meeting the requirements for a key pole due to 'complicated rock-magnetic behaviour'. We do not seek to discredit the Devonian portions of APWPs, but highlight these issues to show that upon closer inspection nearly all Devonian paleomagnetic data are problematic. It is noteworthy that the Devonian part of the APWP of Torsvik et al. (2012) includes only one study that was published in the last 25 years (E. Tohver, pers.comm., 2012; likely equating to Hansma et al., 2015) which is itself highly problematic (as discussed earlier); all other data on which the APWP is based are from older studies.

For the Devonian, it almost seems that the smaller a dataset is, the more likely it is to provide unambiguous results. Larger studies often show results that cannot be explained by the authors, as they show groups of directions that either cannot be explained, or have resulted in scenarios involving large tectonic rotations, extreme plate speeds, or episodes of true polar wander. This has sometimes produced fierce debate (e.g. Lewandowski, 1995; Nawrocki, 1995). When sample size is increased, the risk of obtaining (groups of) complicated directions that cannot be reconciled with other data increases. This can be seen for example in the study of Bazhenov et al. (2013) who extended the sampling of Levashova et al. (2007). The study of Bazhenov et al. (2013) reports directions from a thick pile of $>80$ lavas in Kyrgyzstan that have a Frasnian (Late Devonian) age. The authors interpret their data as suggesting that these lavas have not experienced significant 
remagnetisation. Indeed, this is one of the few studies that do not report Kiaman overprints, with the only overprint resembling a present day field direction. The authors find that the directions from part of their lava succession shows secular variation (secular variation describes the changes in the magnetic field on timescales of typically several tens of thousands of years or less) that is several times greater than in another part of the lavas that gives secular variation estimates that are more consistent with a predominantly dipolar field that is aligned with the Earth's rotation axis (GAD). Other examples include Hawkins et al. (2019), who show directions of Kravchinsky et al. (2002), but also show additional directions that were not published in the original study. A similar situation is observed for the Cheviot Hills lavas in the north of England, where Hawkins (2018) shows more directional groups than the original study of Thorning (1974), which is included in the APWP of Torsvik et al. (2012). Grabowski and Nawrocki (2001) find several directional groups in middle to upper Devonian sediments from Poland, which they state they cannot all simultaneously explain (see also Fig. 18). Sallomy and Piper (1973) describe a distribution of directions that is not simply antipodal. They find two groups that they interpret as normal and reverse polarity, then sites classed as groups $A$ and $B$, and then 9 further 'unclassified' sites. The directions from the Sallomy and Piper (1973) study were reanalysed by Shatsillo and Pavlov (2019), who interpret them as due to non-dipolar behaviour of the field during the Devonian.

Directional groups are common in volcanic successions (e.g. Knight et al., 2004; Van Der Boon et al., 2017), as volcanic rocks are formed rapidly, and do not average out secular variation. If directional groups are also seen in sedimentary rocks, as the study of Grabowski and Nawrocki (2001) seems to suggest, this means that the field would have stayed in a relatively stable configuration for a large amount of time, considering that sediments usually average out secular variation due to their slow deposition. Martin (1975) hypothesised that the sampled interval in their study on Middle Devonian limestone sampled a normal polarity interval, a reverse polarity interval, and a transitional interval in which the field reverses polarity, and secular variation might not be averaged out. Considering the relatively slow sedimentation rates for limestones, this is an unusual conclusion. Their normal and reverse polarities are furthermore not antipodal. Directional groups and extreme scatter that are seen in these studies are difficult to explain by remagnetisation (e.g. Løvlie et al., 1984), which would have likely led to more consistent directions.

In summary, the APWPs for the continental plates in the Devonian rely mostly on sparse data, for which palaeopole quality is hard to assess due to the absence of supplementary data. The number of paleopoles that are considered reliable has decreased since the 1970's (e.g. Mac Niocaill and Smethurst, 1994; Morel and Irving, 1978; Torsvik et al., 2012). The general characteristics that arise from Devonian data, are that studies have often found several groups of directions that cannot all be simultaneously explained, or the scatter in directions is extremely large, so directional averaging is unwise. Due to the positive-outcome bias that exists in most fields of science (e.g. Fanelli, 2012), one wonders whether this data scarcity from Devonian paleomagnetic studies is due to non-positive results, or a lack of study in the Devonian. Studies are sometimes rejected because the data is deemed unreliable by reviewers, or authors have invoked peculiar regional tectonics, extreme plate speeds or true polar wander in order to explain non-dipolarity or scatter. Extensive rock magnetic studies may be required by reviewers to supplement datasets (e.g. Bazhenov et al., 2013), or the results are too complex to interpret and authors might refrain from publishing their Devonian datasets (e.g. Powerman et al., 2013).

\subsection{Studies of geomagnetic field behaviour}

Paleointensity studies typically provide snapshots of the strength of the magnetic field, and obtaining a continuous record throughout the Devonian will require many studies. All the paleointensity data spanning the interval 200-500 Ma have recently been reassessed by Hawkins et al. (2020), who conclude that paleointensities express an extremely weak magnetic field throughout the Devonian, with some outliers during the Early Devonian (around $400 \mathrm{Ma}$ ), a time period for which there are both weak and strong paleointensity results. It is possible that the field dropped in strength from weak in the Early Devonian to extremely weak in 
the Middle and Late Devonian, but many more paleointensity data are needed to verify this. Since Sallomy and Piper (1973), the Devonian field has been suggested to have a strength that was an order of magnitude lower than the modern field. Paleointensity studies from volcanic rocks have supported this nearly unanimously, revealing a weak to very weak field (e.g. Briden, 1966; Didenko and Pechersky, 1989). Until recently, many measurements of the Palaeozoic paleointensity were acquired using techniques that are not considered to meet modern standards of reliability. Several recent studies (Hawkins et al., 2020, 2019; Shcherbakova et al., 2017) have, however, confirmed their central observation - the field in the Devonian and early Carboniferous, was unusually weak compared to any subsequent period.

Kulakov et al. (2019) made a compilation of all paleointensity results from 65-200 Ma. They determined a longterm average of the field between 65-200 Ma (Cretaceous-Jurassic) at around $40 \mathrm{Z} \mathrm{Am}^{2}$ ( $\mathrm{Z}$ equals $10^{21}$ ), while the modern field is stronger, around $80 \mathrm{Z} \mathrm{Am}^{2}$ (Thébault et al., 2015). The field in the Devonian is thus much weaker (Hawkins et al., 2019; Shcherbakova et al., 2017), with a median value of $17 \mathrm{Z} \mathrm{Am}^{2}$ (Hawkins et al., 2020). Hawkins et al. (2020) suggest this low field interval extended for at least 80 Myr, from the Early Devonian into the early Carboniferous and named it the Mid-Palaeozoic Dipole Low.

Here we investigate whether the time-averaged strength of the magnetic field changed during the Devonian. Robust estimates of the paleofield are challenging to obtain due to the ubiquitous presence of non-ideal magnetic recorders which are prone to laboratory-induced alteration. Typical paleointensity studies have a success rate of $\sim 20 \%$; this effect is further complicated by two additional factors (Tauxe and Yamazaki, 2007). Firstly, early paleomagnetic techniques had variable capability of recognizing spurious magnetizations, and community standards on data reporting have since evolved to include metrics on data quality. Thus, early studies require careful inspection and/or removal from analyses if unsuitable measurements are recognized (Biggin and Paterson, 2014). Secondly, larger (i.e., multidomain) magnetic grains can represent a substantial fraction of the remanence magnetization in some rocks. Multidomain grains have geologically short magnetic relaxation times (<<100 Myr; Dunlop and Özdemir, 1997), and while these rocks may be suitable for paleodirection/magnetostratigraphic studies, these samples can yield unreliable paleointensities in older geologic materials. For these reasons, careful selection criteria must be balanced with the desire to maximize the quantity of data included in a description of long-term field behaviour. Hawkins et al. (2020) expanded the dataset of field strength estimates for the Devonian and assessed the reliability of paleointensity data. Using the data set compiled by Hawkins et al. (2020), we selected sites which met the following criteria for our analysis: 1) directions were not identified as transitional in polarity by authors of the study, 2) there are at least 3 intensity determinations per site, and 3$)$ site data are of reasonable quality $\left(Q_{P I} \geq 3\right.$, following Biggin and Paterson, 2014). Virtual dipole moments were determined using published inclination and paleointensity data; if inclination data were not available (14/120 sites), a virtual axial dipole moment was determined assuming an equatorial site to provide an upper bound on dipole field strength. Here, paleointensity sites refer to volcanic cooling units recording "instantaneous" snapshots of the field. Selected data were grouped into 1 Myr bins to produce time-averaged estimates; only bins which contained more than one site were considered for characterizing the trend (see Fig. 21). Different selection criteria were explored (either a stricter one requiring $Q_{P I}$ criteria $A G E+M D+A L T+D I R$ to have passed, number of intensity determinations $\geq 3$, and number of sites per bin $\geq 3$, or a more relaxed criteria accepting any non-transitional paleointensity sites with at least 3 determinations and bins with only one site). Note that the DIR criterion (the presence of sufficiently high quality paleodirectional data for the same remanence as the paleointensity) was assessed beyond the 9 criteria considered in Hawkins et al. (2020). These alternate selection criteria do not substantially change the broad interpretation of a very weak field during the Middle to Late Devonian. However, the stricter selection criteria may address a potential suspicion of a low-field bias (Smirnov et al., 2017) by only selecting sites where magnetizations carried by non-ideal multidomain carriers are removed prior to the paleointensity experiment. 
Filter: $Q_{P I} \geq 3, N_{I N T} \geq 3, N_{B I N} \geq 2$
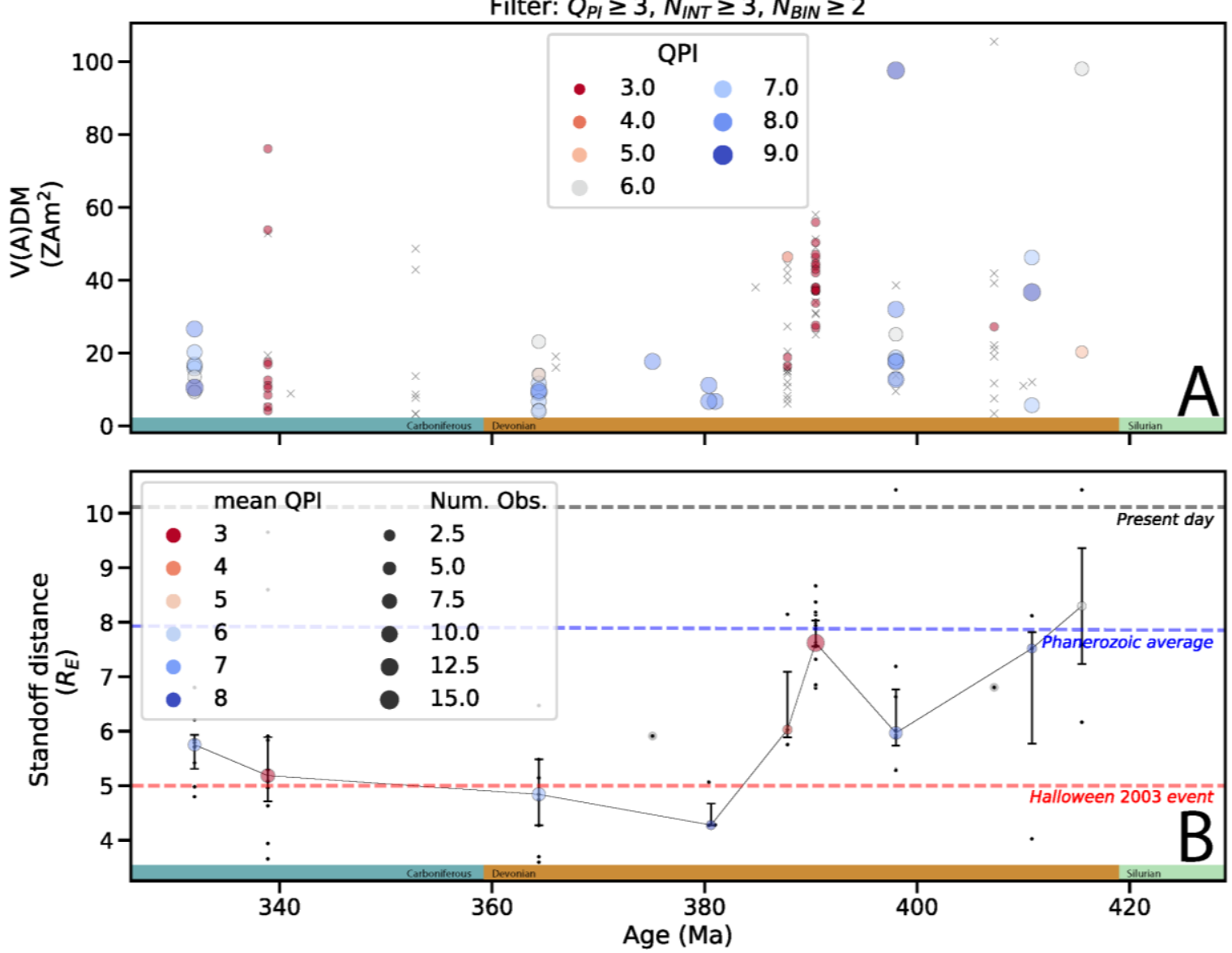

Fig. 21 - A. Virtual (axial) dipole moments during the Devonian; studies included in the dataset are listed in Supplementary file S10. Symbol size and colour show $Q_{P 1}$ score; symbols marked with an "x" were not included in the standoff distance analysis. B. Median magnetopause standoff distance in Earth radii. Symbol size shows the number of sites within a $1 \mathrm{Myr}$ bin; symbol colour shows the mean $Q_{P I}$ score for that bin. Uncertainty bars show the interquartile range for each bin. Small dots show individual site standoff estimates; grey circles show age bins containing a single site. Ages for the SilurianDevonian and Devonian-Carboniferous boundaries from Becker et al. (2020). Dashed lines show standoff distance for present day (black), long term Phanerozoic average (assuming mean dipole moment of $42 \mathrm{ZAm}^{2}$, Selkin and Tauxe, 2000; blue), and standoff during an extreme space weather event (Halloween 2003 event, Rosenqvist et al., 2005; red).

Organizing the data in this fashion suggests a field that was somewhat weaker than the Phanerozoic average during the Early Devonian and steadily weakened during the Middle Devonian, reaching a minimum by 380 Ma (Late Devonian). This interval of extremely weak field appears to have lasted for $\sim 40-80 \mathrm{Myr}$, although constraining the duration is hampered by the lack of sufficiently high quality paleointensity data for the 340$360 \mathrm{Ma}$ interval. By the onset of the Kiaman Superchron at ca. $315 \mathrm{Ma}$, the field strength had recovered to reach or exceed the Phanerozoic mean field.

Two other aspects of long-term field behaviour that can be assessed using paleomagnetic records are average polarity reversal frequency (e.g. Biggin et al., 2012) and paleosecular variation (e.g. Doubrovine et al., 2019). Hansma et al. (2015) claimed to observe a minimum 44 reversals during the late Devonian (a 24 Myr interval) translating to a reversal frequency of $\sim 2 \mathrm{Myr}^{-1}$. However, the unusual treatment of data applied to a uniformly distributed dataset (see Section 6.1) raises serious questions over the validity of this reversal record. Bazhenov et al. (2013) also reported unusual paleosecular variation behaviour in a study of lavas in Kazakhstan (see Section 6.2). As noted, secular variation appears to have been enhanced for at least part of the Late Devonian. High scatter of directions caused by secular variation, if confirmed, would suggest a reduced role of the axial dipole in the morphology of the Late Devonian field (Biggin et al., 2020). 


\section{Explanations for suboptimal paleomagnetic results from Devonian rocks}

A wide-ranging review of Devonian paleomagnetism has highlighted that there is a global paucity of published paleomagnetic studies. Most studies on Devonian paleomagnetism are decades old, and may not contain the data detail and scientific rigour that is typically expected of contemporary studies. Where recent studies have been published (Hansma et al., 2015; Hawkins, 2018; Hawkins et al., 2019; Shatsillo and Pavlov, 2019), the data tend to represent paleomagnetic directions that are more scattered than usual, in some cases to an extreme extent. We consider below different reasons for why the Devonian paleomagnetic results may be odd.

\subsection{A weak field}

The lack of reliable paleomagnetic data for the Devonian has long been a possible indicator for a weak magnetic field, and this has been confirmed by modern studies of paleointensity. A weak magnetic field will have led to weakly magnetised rocks, which enhance the risk of overprinting after the Devonian, in times when the field was stronger, and increased the difficulty of obtaining paleomagnetic data in sediments due to magnetometer sensitivity limits. Indeed, Devonian rocks often have an extremely weak magnetisation, which often makes exhaustive quantitative analysis challenging. The Devonian has partly acquired a bad reputation for paleomagnetic studies due to studies from the 1960's, when equipment was much less sensitive than today. However, even now, with the most sensitive magnetometers, measuring Devonian carbonates is still a big challenge as was found in this study. Weak paleomagnetic signals are common for the Devonian. For example, Jeleńska et al. (2015) report very weak NRM intensities and mention that this hampers measurements and interpretation. NRM intensities for Devonian rocks are generally in the range of $10^{-3} \mathrm{~A} / \mathrm{m}$ or below. Although sediments are generally weaker than igneous rocks, with values down to $10^{-6} \mathrm{~A} / \mathrm{m}$ (e.g. Claesson, 1979; Kadziałko-Hofmokl et al., 1999; Kent, 1979), there are studies that report very weak NRM intensities for igneous rocks, with values in the range of $10^{-4}-10^{-5} \mathrm{~A} / \mathrm{m}$ (e.g. Hargraves et al., 1987; Jeleńska et al., 1995; Sallomy and Piper, 1973). Also Levashova et al. (2003) mention that the Middle Devonian basalts they sampled have susceptibilities and NRM intensities that are up to 100 times lower than typical basalts, but they are completely remagnetised. Normally, NRM intensities of igneous rocks are much higher, in the range of 0.1-10 A/m (Dunlop and Özdemir, 1997). Considering the linear relationship between the field and magnetisation (e.g. Dunlop, 2011), and the field in the Devonian likely being at most around 10 times weaker than the modern field, a weak field is likely not the sole explanation for weakly magnetised basalts.

\subsection{Overprinting}

When looking at secondary components, recent field as well as Kiaman overprints are common for the Devonian, and there is certainly some truth to overprinting being a reason for poor results from Devonian rocks. There was of course ample time and opportunity for remagnetisation after the Devonian. Globally, many areas were affected by the Variscan orogeny during the Carboniferous and Permian, a time when the magnetic field was stable in reversed polarity for millions of years (the Kiaman superchron). Geodynamo models suggest that during superchrons, the field is strong (e.g. Driscoll and Olson, 2011), although for the Kiaman, paleointensity estimates differ, and while most studies suggest a strong field (e.g. Cottrell et al., 2008), others suggest a weaker field (e.g. Garcia et al., 2006). Either way, mountain building in the late Carboniferous-early Permian provided excellent remagnetisation conditions, and it is thought that recovery of the magnetic signal from Devonian rocks is troubling mostly due to remagnetisation during the Kiaman superchron. Remagnetisation could have been achieved by heating of Devonian rocks due to burial or intrusions, resulting in thermoremanent magnetisations (TRM), or by remineralisation through fluids, resulting in chemical remanent magnetisations (CRM). A Kiaman overprint is indeed seen in most studies, as discussed earlier, and Devonian rocks that have no Kiaman overprint are rare, but do exist (e.g. Bazhenov et al., 2013). However, overprints are not always consistent as would be expected. This is outlined in detail in Shatsillo and Pavlov (2019), and our new data also shows that even when rocks are not expected to have been overprint by the usual processes (significant heating or remineralisation), Devonian rocks do not show straightforward paleomagnetic directions. Furthermore, the remagnetisation argument also holds true for older time periods. 
For pre-Devonian times, however, reliable paleomagnetic data exist, even for periods where the field was reportedly hyperreversing, such as the Middle Cambrian (e.g. Gallet et al., 2019), or the Ediacaran (Bazhenov et al., 2016; Kodama, 2020). It is striking that good results can be obtained from the Ediacaran, as the field in the Ediacaran was likely as weak as, or weaker than in the Devonian (Bono et al., 2019; Shcherbakova et al., 2020; Thallner et al., 2020), which begs the question: was the field in the Devonian of a different character to that of the field in the Ediacaran?

\subsection{A non-GAD field}

The approach of Hansma et al. (2015), using a $45^{\circ}$ cut-off, implicitly assumes that the field is a dipole, and the dipole is approximately aligned with the rotation axis of the earth (GAD field). Any fixed cut-off approach assumes that the field is a relatively stable dipole and spends little time in transitional directions, since these are eliminated by the cut-off. As nearly half of the data are excluded based on the $45^{\circ}$ cut-off in the study of Hansma et al. (2015), it seems that, if their data truly represent the Devonian magnetic field, a geocentric axial dipole is not an accurate description for the Devonian magnetic field. Shatsillo and Pavlov (2019) have argued for a significant contribution of an equatorial dipole to the Devonian magnetic field. The assumption that a time-averaged field coincides with a geocentric axial dipole is a key assumption that underlies plate tectonic reconstructions. Thus, if the field in the Devonian is indeed different from a GAD field, this may perhaps be a way of explaining contrasting paleopole studies that have resulted in the conflicting X-and Y-paths.

\subsection{Summary}

The high Q-scores for Devonian paleomagnetic data in the APWP indicate that the scarcity of reliable Devonian data is not purely a problem of remagnetisation. As our newly obtained data also show, rocks that are well qualified to have reliably recorded the magnetic field at time of formation often give ambiguous results, and obtaining accurate paleomagnetic data even from 'good' rocks is challenging. We interpret this to be a further indication that there might have been something in the nature of the magnetic field during the Devonian, and it is not solely a problem of the rocks being overprinted. It is striking that few (if any) studies show unambiguous Devonian paleomagnetic results, although we note that it is often difficult to judge the quality of the data, as many of the studies are very old (25-60 years), and supplementary data is generally absent.

There have been several studies to suggest that the field during the Devonian was very different from the Earth's magnetic field today (e.g. Hawkins et al., 2019; Shatsillo and Pavlov, 2019; Shcherbakova et al., 2017). The records obtained in these studies were all done on volcanic rocks, which have thermal remanent magnetisations (TRMs), that are normally stronger than the detrital and post-depositional remanent magnetisations (DRMs and PDRMs) in sedimentary rocks that magnetostratigraphy relies on. Shatsillo and Pavlov (2019) argue that directions in the Early and Middle Devonian are not bimodal and antipodal, as expected from a GAD field, but show different clusters. Sedimentary rocks average out paleosecular variation, while volcanic rocks cool rapidly, and do not average out secular variation. So for sedimentary rocks, the effect might be that several directional clouds are contained within a single sample, and no reliable Devonian direction can be obtained from the sedimentary sample. This is also the case for slow-cooling intrusive rocks, and Shatsillo and Pavlov (2019) argue that the results of Piper (2007) were not caused by true polar wander, as argued by Piper, but rather due to obfuscation of the paleomagnetic signal by slow cooling.

If results from other studies are similar to those we present in this study, even determining (Kiaman) remagnetisations is not straightforward. Determining characteristic remanent magnetisations (ChRM) and ascribing these to a primary Devonian origin is also difficult. If the Devonian magnetic field was truly weak or exceptional, the only way to increase our understanding of it is by collating and considering all results that have, thus far, been considered 'negative'. We emphasise the need for more studies and encourage scientists to publish their Devonian paleomagnetic results even if they are complex or appear unreliable. We also stress the risk associated with over-interpreting results and invoking peculiar regional tectonics or significant episodes of true polar wander, as it can be complicated afterwards to assess the data underlying these 
explanations. We think that the conventional view on the Devonian as 'all overprint' is unlikely to be the sole explanation for the scarcity of good Devonian paleomagnetic results, as overprinting cannot explain the presence of directional groups or extreme directional scatter.

\section{Did the field have an impact on life in the Devonian?}

The Devonian was a time of many biotic crises, particularly the Middle and Late Devonian (Figure 22). Becker et al., (2016) categorise the biotic crises based on their severity, with first order events the most severe mass extinctions, down to fourth order events in which there was a disappearance of fewer, but widespread groups in response to a global trigger. Other events during the Devonian were faunal blooms, radiations and sudden spreads of organisms linked to transgressions. There has been much debate on the causes of the Late Devonian mass extinctions, with a variety of suggested triggers, including explosive volcanism, global warming, global cooling, or a multi-causal process, due to the fact that the events themselves consist of multiple steps (e.g. Aretz, 2021; Boyer et al., 2021; Fields et al., 2020; Kaiho et al., 2021; Marshall, 2020; McGhee and Racki, 2021; Paschall et al., 2019).

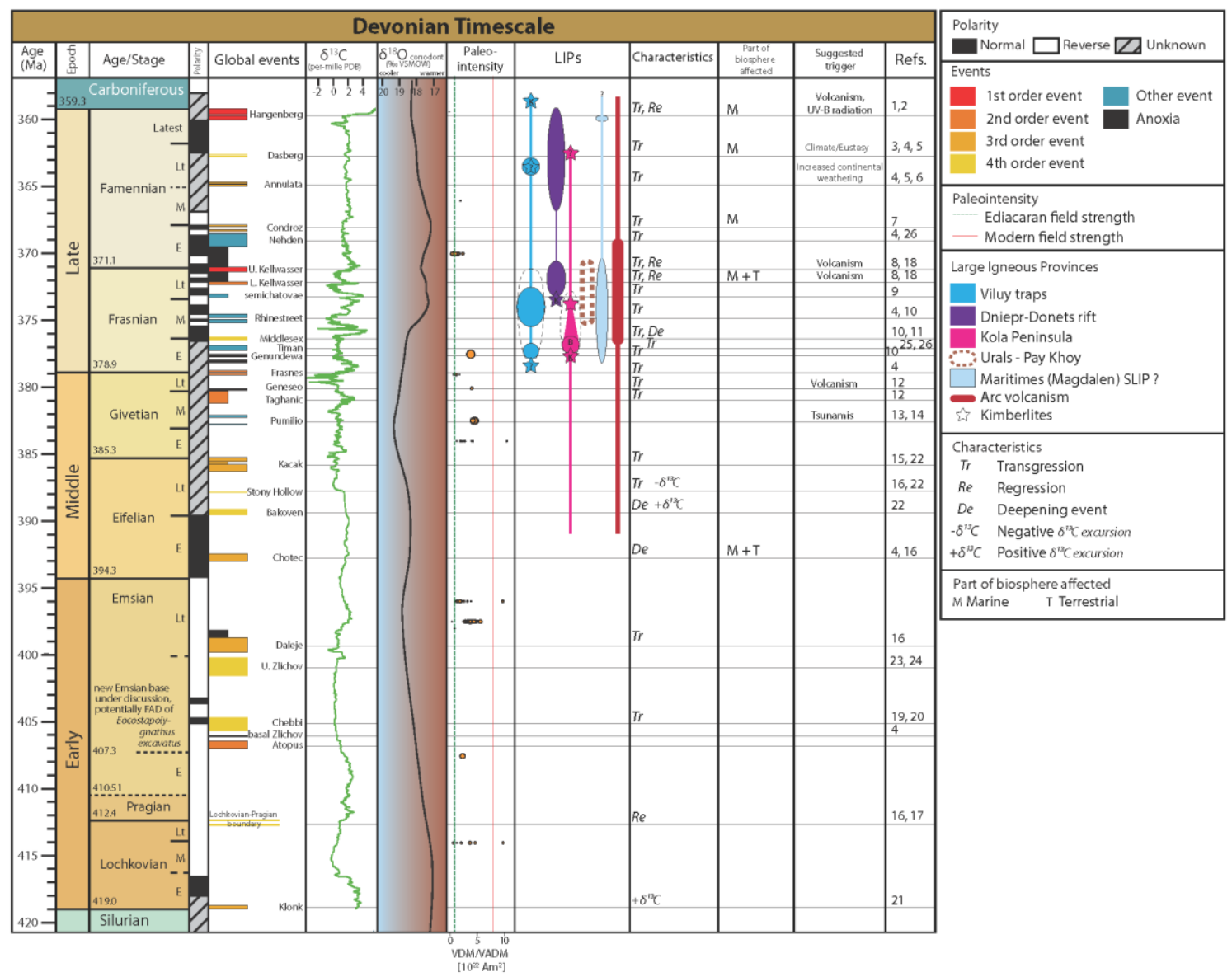

Fig. 22 - Overview of biotic events and crises in the Devonian. Timescale from GTS2020 (Becker et al., 2020), biotic crises and anoxia from Becker et al. (2020, 2016), paleointensities from the PINT database (Biggin et al., 2015), volcanic pulses from Racki (2020). In order to scale the volcanic pulses to the timescale of Becker et al., (2020), we used the DevonianCarboniferous boundary, Frasnian-Famennian and Givetian-Frasnian boundaries in the figure of Racki (2020). $M=$ marine realm, T = terrestrial realm. References 1 - Pisarzowska et al. (2020), 2 - Marshall et al. (2020), 3 - Hartenfels and Becker (2009), 4 - House (2002), 5- Hartenfels and Becker (2016), 6 - Percival et al. (2019), 7 - Becker et al. (2016), 8 - Racki et al. (2018), 9 - Ziegler and Sandberg (1997), 10 - House and Kirchgasser (1993), 11 - Sandberg et al. (2002), 12- Brett et al. (2011), 13 - Lottmann (1990), 14 - Becker and Aboussalam (2004), 15 - Königshof et al. (2016), 16 - Walliser (1996), 17 Chlupác and Kukal (1988), 18 - Carmichael et al. (2019), 19 - Becker et al. (2020), 20 - Becker and Aboussalam (2011) 21 Małkowski and Racki (2009), 22 - DeSantis and Brett (2011), 23 - García-Alcalde (1997), 24 - Tonarová et al. (2017), 25 Racki et al. (2004), 26 - Becker and House (1997). 
Recently, the study of Marshall et al. (2020) has linked the terrestrial phase of the Hangenberg event at the Devonian-Carboniferous boundary to an increase in ultraviolet (specifically, UV-B) radiation, which they hypothesize to be caused by an increase in convective transport of $\mathrm{ClO}$ (chlorine monoxide) through global warming. Fields et al. (2020) dispute this cause and have instead suggested that the increase in UV-B radiation during the Hangenberg event could have been caused by supernovae. Another proposed mechanism for partial destruction of the ozone layer is by explosive volcanism (e.g. Kutterolf et al., 2013; Self, 2015). Volcanism has been often invoked to be a main factor in end Devonian biotic crises, but there has been considerable discussion on which volcanic province was responsible (e.g. Racki, 2020). There are several candidates, such as the large igneous province of the Viluy traps in Siberia, the Kola traps in Russia and the Pripyat-Dniepr-Donets province (Kravchinsky, 2012) (see also Fig. 22). Sudden increases in UV-B radiation reaching the surface of the Earth have also been linked to a weak shielding of the Earth's atmosphere by the magnetic field (e.g. Meert et al., 2016). Earth's magnetic field protects the atmosphere by deflecting charged particles coming from the sun. When the magnetic field is weak, the solar wind is not deflected to the same extent, and can reach the upper atmosphere, where they interact with the ozone layer. These charged particles dissociate $\mathrm{N}_{2}$ and $\mathrm{O}_{2}$, which contributes to the formation of $\mathrm{NO}_{x}$ and $\mathrm{HO}_{x}$ in the middle atmosphere, which in turn are key in the depletion of stratospheric ozone (e.g. Meert et al., 2016; Vogt et al., 2007). The depletion of the ozone layer increases UV-B radiation reaching Earth's surface.

Understanding whether the weak field during Devonian allowed for increased penetration of charged solar particles into the atmosphere (relative to the present day or Phanerozoic average) requires understanding the strength and shape of the Devonian magnetosphere and its concomitant magnetic shielding. One means for quantifying the degree of magnetospheric shielding by the geomagnetic field is to determine the distance of the magnetopause, the point at which solar wind pressure is balanced by the magnetic field. This can provide a first-order approximation of the degree of magnetic shielding; here we use the assumptions that virtual dipole moments represent a strictly dipole field, and that non-dipole contributions to field (both instantaneous and secular variation) resemble the present day field. These are conservative assumptions which are expected to maximize the estimated magnetic shielding during the Devonian (following the approach of Tarduno et al., 2010). The resulting magnetopause estimates are presented in Figure 21b.

The present day magnetopause is observed to be $\sim 10$ Earth radii $\left(R_{E}\right)$; under normal conditions, this value can fluctuate on annual time scales by $\leq 1 \mathrm{R}_{\mathrm{E}}$ due to changes in the location of the magnetic pole relative to the spin axis. Estimated magnetic standoff distance during the Early Devonian is consistent with the standoff distance for the long-term Phanerozoic average $\left(\sim 8 R_{E}\right)$. During the Late Devonian nadir in field strength, the standoff distance was reduced to $\sim 4-5 R_{E}$. This distance is comparable to, or less than, the standoff distance minima observed during the Halloween 2003 event, a solar storm event which resulted in sufficient penetration of charged particles to generate auroras at low latitudes and disrupt the electrical grid in Sweden (Rosenqvist et al., 2005). However, unlike the Halloween 2003 event, which lasted on the order of days and can be seen as an ephemeral reduction in shielding, the standoff distance estimated for the Late Devonian represents the average standoff for millions to tens of millions of years. This reduction in shielding could be further exacerbated by magnetic storms and coronal mass ejections during the Devonian. Typical space weather can reduce the present-day magnetopause by $\sim 1-2 R_{E}$ (Voigt, 1995), with greater reduction during more extreme events (e.g., Halloween 2003 event). If the paleomagnetosphere during the Devonian was substantially weaker and potentially less dipolar, as suggested by the paleomagnetic data, then shielding reductions during space weather events could be greater.

An additional property of the paleomagnetosphere is the magnetic polar cap: the region defined by open dipole field lines, inside which charged solar ions are funnelled towards Earth's surface. A second-order consequence of the polar cap is the occurrence of polar auroras at the lower latitudinal boundary of the polar cap. If the time-averaged paleomagnetic field is assumed to be fairly GAD-like during the Late Devonian, the lower bound of the polar cap $\left(\lambda_{P}\right)$ and its surface area, can be estimated (following the approach of Siscoe and 
Chen (1975); see Supplementary file S8). During the Early Devonian, the median $\lambda_{p}$ is estimated to be $68.9^{\circ}$ (with an interquartile range spanning $66.2^{\circ}$ to $69.5^{\circ}$; see Figure $23 a$ ) which is somewhat lower than the present day latitude $\left(71.9^{\circ}\right.$; Siscoe and Chen, 1975) and suggests an increase in the relative surface area of the polar cap of $\sim 1.5$ times the present day shielding (Fig. 23b). Once the field was reduced during the Late Devonian, the polar cap extended further southward to $63.7^{\circ}$ (with an interquartile range spanning $61.8^{\circ}$ to $65.0^{\circ}$; see Figure 23c). This represents an increase in the surface area (relative to today) of a factor of $\sim 2$ (Fig. 23c), broadening the region where Earth's atmospheric ozone could be eroded due to dissociation of $\mathrm{N}_{2}$ and $\mathrm{O}_{2}$.
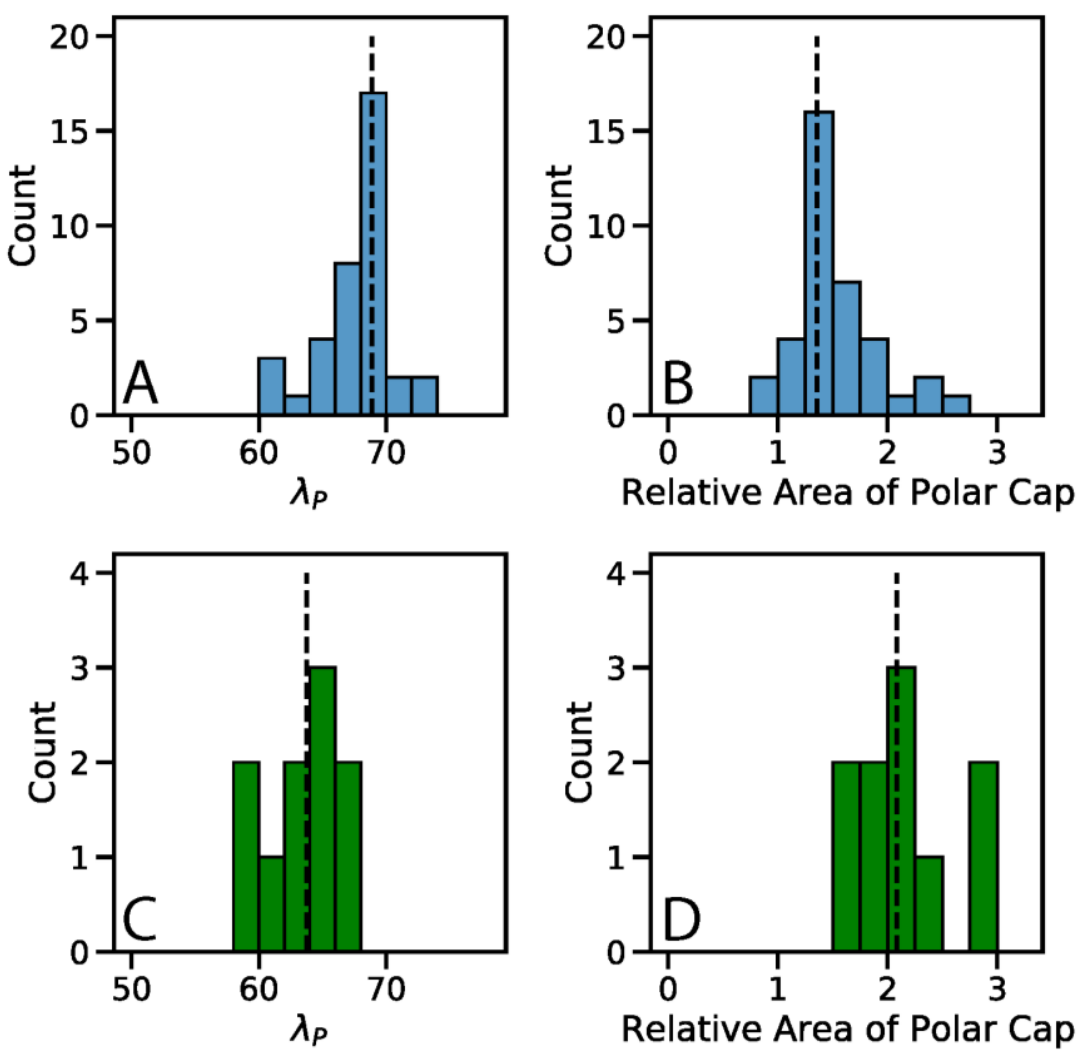

Fig. 23 - Polar cap angle $\lambda_{P}$ (left) and area relative to present day polar cap (right) estimated for each site V(A)DM. Dashed vertical lines mark median value. A and B: early Devonian (380-420 Ma); C and D: late Devonian (340-380 Ma).

If the time-averaged field was substantially different from GAD, it is probable that the standoff distance would be reduced and the meaningfulness of the polar cap description (with associated $\lambda_{P}$ ) would diminish. As the contribution of a quadrupolar field increases relative to the dipole moment (a scenario representing the longest wavelength description of the non-dipole field), it is expected that $\lambda_{p}$ could migrate upwards of $\sim 10^{\circ}$ towards the equator (Vogt et al., 2007). In a more extreme departure from GAD, models of the paleomagnetosphere during a simulated geomagnetic reversal (Stadelmann, 2004) suggest all latitudes could be susceptible to large flux of charged particles during an extended, weak non-dipolar field.

We hypothesise that the magnetic field during the Devonian was in such a weak and unstable state as to constitute a substantial additional hazard for life at this time. With our current knowledge, it is hard to estimate the contribution a weak magnetic field had in biotic crises in the Devonian. The field could have triggered specific biotic crises associated with its long-term secular variation (i.e. on the $10^{5}-10^{6}$ year timescale), or its longer-term state (i.e. on the $10^{7}-10^{8}$ year timescale) could have been a constant factor that enabled other triggers to have a bigger impact on the biosphere. Based on all the evidence from paleointensity studies, we know that Earth's magnetic field was extremely weak during the Devonian, and possibly periodically had a non-dipolar configuration. Life during the Devonian thus might have been continuously 'on the edge' because of the weak protection of the atmosphere by the magnetic field, which meant that other triggers such as volcanism could have more easily enabled biological crises. The weak magnetic field could thus 
be one of the influencing factors in the multi-causal model that is favoured for the Late Devonian biotic crises (Racki, 2020). However, it is also possible that the field during the Devonian directly enabled biological crises through depletion of the ozone layer, which allowed more UV-B radiation to reach Earth's surface. Although it would be expected that malformed spores would be more widespread, and associated with other parts of the Devonian, instead of in distinctive intervals as the study of Marshall et al. (2020) suggests.

Future studies might provide perspectives on the causes for ozone depletion by looking at the duration of increased UV-B radiation, and assessing if there is evidence for UV-B radiation in the Early and Middle Devonian. The timescales on which UV-B radiation interacts with life on Earth, and the latitudes for which this effect is greatest are different for different causes of ozone layer depletion. For explosive volcanism, Self (2015) mentions that the increase in UV-B radiation reaches high and mid-latitudes, and the effect lasts for a few years after the explosive eruption. Fields et al. (2020) discuss the scenario presented by Marshall et al. (2020), and note that the effect of the proposed mechanism would last only a few weeks. While the timescales associated with the Earth's magnetic field are highly variable (hours to millions of years), we think it is most plausible that the field was extremely weak for several tens of millions of years, as suggested by Hawkins et al. (2020), and thus acted as a continuous stressor.

\section{Future work on the paleomagnetism of Devonian rocks}

Despite substantial amount of effort being expended, the body of knowledge concerned with most aspects of paleomagnetism in the Devonian remains small with respect to other geologic periods. Negative results are seldom published so it is likely that there may have been many more attempts at obtaining magnetostratigraphic records and other paleomagnetic data from Devonian rocks than the ones cited here. The timing of polarity changes during the Devonian remains uncertain. Furthermore, paleopole constraints on paleogeography through the Devonian are fragile and prone to controversial interpretations, a situation which is unfortunate. A Devonian GPTS would fill in a significant part of the Paleozoic gap in the timescale. It would have great utility in high resolution global correlation, since the Devonian was a time of many global crises, including one of the 'big five' mass extinctions. For the study of the Earth's magnetic field, polarity records for the Devonian would allow assessment of the reversal frequency of an interval of some 60 million years duration. Reversal frequencies for other periods in geological history are a key constraint on the operation and evolution of the geodynamo with strong implications for mantle-forcing potentially linked to surface processes (e.g. Amit and Olson, 2015; Hounslow et al., 2018). Obtaining reliable Devonian paleopoles would be of huge benefit to precisely constrain paleolatitudes of the continents, and significantly improve paleogeographic reconstructions.

Presently, the creation of a GPTS for the Devonian appears to be a task that may take several more decades of study to resolve. If the field in the Devonian was indeed multipolar in certain intervals, creating a GPTS for those intervals may be impossible, as it is reliant on the field being dipolar. To further understand the enigmatic field in the Devonian, we need more paleomagnetic data tightly linked to detailed stratigraphicbased studies both on sediments and volcanic rocks. Our study of Devonian paleomagnetism raises rather more questions than it answers. We hope that our study will incite new paleomagnetic studies on Devonian rocks, in order to improve this situation. Furthermore, if studies can demonstrate, as we have attempted here, that the lack of conventional utility of a paleomagnetic dataset cannot readily be ascribed to the recording medium, then this serves as a direct test of the central hypothesis outlined here. In any case, we urge the need for authors to supply their full data with the publications. Currently, many of the old data is difficult to assess, as they lack supplementary information.

Studies on (malformed) spores could also aid in assessing burial temperatures, and thus are a useful tool in assessing the likelihood of overprinting of the paleomagnetic signal. Marshall et al., (2020) mention that the thermal maturity of the spores in their studied section indicates a burial temperature of $107^{\circ} \mathrm{C}$, a temperature 
at which it is likely that the paleomagnetic signal could be preserved. Future studies could focus on determining when the weak field period ended and the magnetic field recovered. It is likely that this is sometime during the Carboniferous, as many Devonian data seem to have late Carboniferous overprints. Data from the Kiaman superchron generally seems robust, indicating that the field must have recovered by then. On the older side, we should look at the latest times for which paleomagnetic data show good results. The Silurian is also generally problematic for paleomagnetism, suggesting that the magnetic field may have also recorded a weak field interval prior to the Devonian, following the weak field interval observed during the Ediacaran (Bono et al., 2019).

If the field was indeed extremely weak and the reduction in magnetic shielding had an influence on life on Earth, there might be more indications for increased UV-B radiation found in the biological record of the Devonian (e.g. Marshall et al., 2020). We suggest that this could be an interesting target for future studies. If there is no evidence for increased UV-B radiation beyond the Late Devonian, this would imply that either the field was weaker or different in the Late Devonian compared to the Early and Middle Devonian, or the field was not a determining factor in the increase in UV-B radiation. Another intriguing question is whether the field could have had an impact on oceanic anoxia, perhaps through a link with partial destruction of the ozone layer, which would have been accompanied by a depletion of oxygen in the atmosphere (e.g. Meert et al., 2016; Vogt et al., 2007). The reverse has already been suggested for the Mesozoic, in which ocean anoxia ended through enrichment of atmospheric oxygen (e.g. Baker et al., 2017; Tsandev and Slomp, 2009).

Another major avenue of future work will be to investigate the mechanism behind the weak field period in the Paleozoic. Studies that modelled the geodynamo have suggested that the formation of the inner core would have caused the field to increase in strength (Driscoll, 2016). A recent estimate for inner core nucleation placed it at $565 \mathrm{Ma}$ (Bono et al., 2019) but the actual timing remains highly contested (Biggin et al., 2015; Kodama et al., 2019; Smirnov et al., 2016; Sprain et al., 2018; Zhang et al., 2020). Furthermore, the theoretically plausible range is extremely broad ( 400-1800 Ma) and encompasses the Devonian (Davies et al., 2015).

While it is therefore not implausible that a weak field existed in the Devonian because of marginal thermal convection ahead of inner core nucleation (in a scenario similar to that advocated by Bono et al., 2019, but 150 Myr later), other explanations exist. In the last $200 \mathrm{Myr}$, the paleomagnetic field is observed to have undergone a long-term cyclic change, plunging into a hyper-reversing weak-field state in the Middle Jurassic, followed by a sharp recovery into the strong and stable Cretaceous Normal Superchron and subsequently monotonically destabilising over the last ca. $100 \mathrm{Myr}$ (Biggin et al., 2012). Such an evolution is very likely linked to changes in conditions at the base of the mantle, influencing heat flow across the core-mantle boundary (CMB) that is ultimately responsible for driving the geodynamo (McFadden and Merrill, 1984). Since 200 Myr may be an emergent timescale of mantle convection (Coltice et al., 2013), it is tempting to view the Devonian as analogous to the Middle Jurassic weak-field hyper-reversing state (but probably more extreme and longer lasting) in a similar ca. 200 Myr cycle occurring previous to the most recent one. In such a scenario, paleomagnetic behaviour again recovered sharply from this weak, unstable state and evolved quickly into a stable, strong superchron (in this case, the Kiaman).

There have been several recent attempts to explain cyclic variations in paleomagnetic behaviour under the assumption that mantle forcing of the geodynamo is the causative mechanism (Amit and Olson, 2015; Biggin et al., 2012; Hounslow et al., 2018). These have all assumed that weak-field, hyper-reversing behaviour such as that invoked for the Devonian occurs as a result of core-mantle heat flow being elevated, globally or equatorially, and/or being more heterogeneous in comparison to more stable intervals. Such distinct coremantle conditions could be related to prior reductions in subduction flux (Hounslow et al., 2018), superplume growth (Amit and Olson, 2015), and/or episodes of true polar wander (Biggin et al., 2012). Biggin et al. (2012) originally assessed the possible effect of true polar wander on the geodynamo in the interval 0-300 Ma using 
the record of Torsvik et al. (2012). They inferred that, in the geodynamo's frame of reference and assuming lowermost mantle heterogeneity similar to that observed today by seismology, core-mantle heat flow was elevated in the equatorial region at the time of the mid-Jurassic reversal hyperactivity. Their proxy for equatorial $\mathrm{CMB}$ heat flow potentially provided an explanation for magnetic reversal behaviour at this time and during the subsequent transition to a non-reversing state in the mid-Cretaceous. Here, we extend this analysis back in time using a 0-450 Ma record of true polar wander (Torsvik et al., 2014).

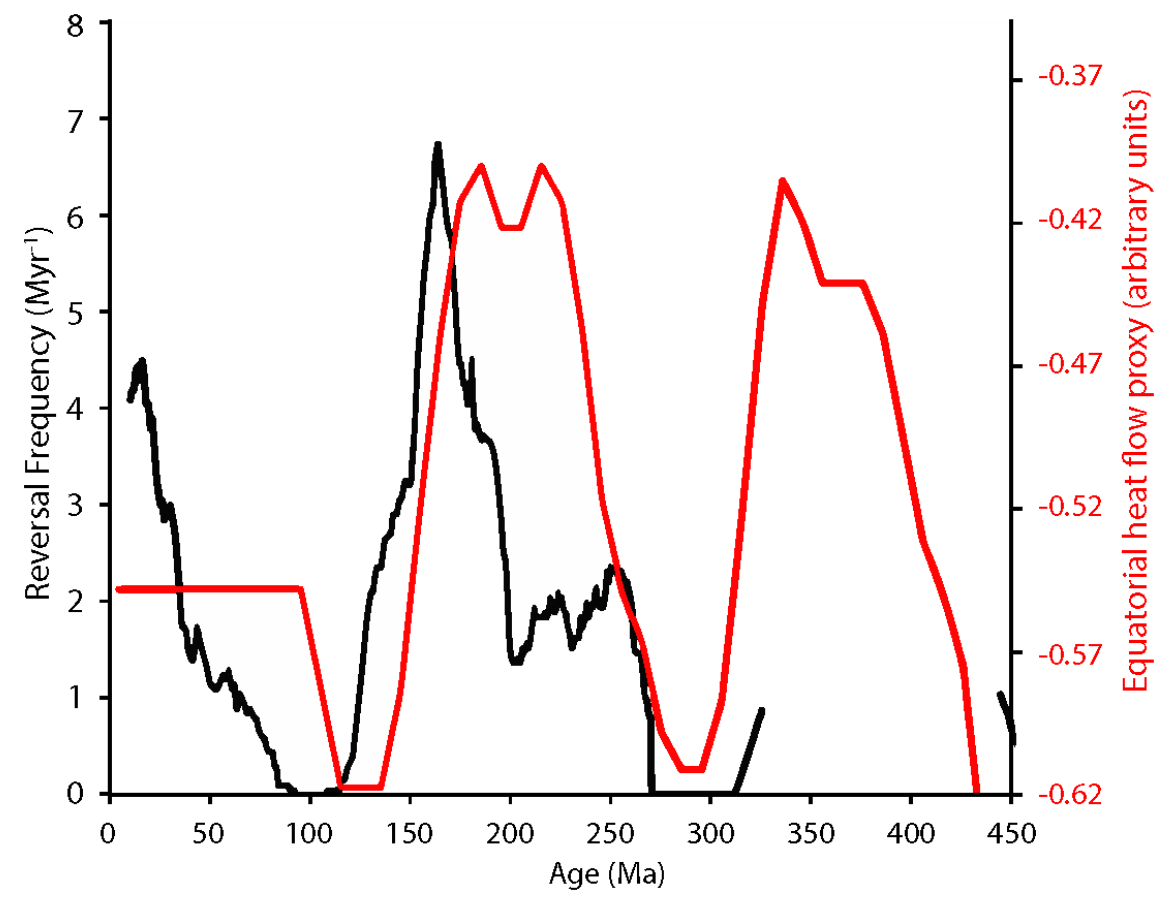

Fig. 24 - Time series since $450 \mathrm{Ma}$ of average geomagnetic polarity reversal frequency (black line) and a proxy for average core-mantle heat flux in an equatorial band (red line). This analysis is identical to that reported in Biggin et al. (2020) but extended from 300 to $450 \mathrm{Ma}$ using the true polar wander model of Torsvik et al. (2014). The proxy for equatorial heat flow is obtained from integrating seismic velocity anomalies (taken from Becker and Boschi, 2002) within a $\pm 10^{\circ}$ latitude band in the palaeomagnetic reference frame after performing rotations in the mantle reference frame to account for true polar wander. For full details of this analysis, the reader is directed to Biggin et al. (2020).

Remarkably, the extended analysis (Figure 24) describes a distinct minimum in the equatorial heat flow proxy in the middle part of the Kiaman Superchron as would be expected if true polar wander played a significant role in controlling reversal frequency in the late Palaeozoic. More pertinently, it also describes a strong peak spanning the Devonian and early Carboniferous, predicting a maximum in reversal frequency at this time. This analysis does not support that true polar wander can account for the entirety of observed changes in paleomagnetic behaviour for the interval 0-450 Ma. Nevertheless, we consider the hypothesis, supported by this analysis, that true polar wander played a role in producing extreme paleomagnetic field behaviour in the Devonian to be worthy of further testing with new datasets and simulations.

\section{Conclusions}

We have presented here new paleomagnetic data from three sections, as well as a detailed review of the literature surrounding Devonian paleomagnetism. This synthesis has yielded the primary conclusion that the geomagnetic field in the Devonian field was, on average, substantially different to that of most of the subsequent Phanerozoic. We have subsequently explored the implications of a weak and potentially less dipole-dominated magnetic field during this interval of geologic history and attempted to outline a clear direction for future research in this area. 
Our newly acquired paleomagnetic data from three Devonian sections provide challenging results. The interpretation of the data is not straightforward, and strong overprints, both by Kiaman (Permo-Carboniferous reverse superchron) and recent fields, are evident. The remaining paleomagnetic signals are of varying quality due in parts to strong component overlap. The Blankenheim section in Germany shows Devonian-like directions of reverse polarity, which agrees with results from previous studies. However, as there are no field tests available, we cannot exclude the possibility that the obtained directions result from a mixture of a recent field and Kiaman overprint. Polish carbonates show results characteristic for a Devonian field of normal polarity, with several samples likely representing reverse polarity. Again, due to the absence of field tests, we cannot rule out that the reverse polarity is a mixture between a recent field and Kiaman overprint. The characteristic directions from the Hume Formation in Canada show extremely large scatter in addition to recent and Kiaman overprints, and we cannot interpret these in a meaningful way.

We have reviewed a significant part of the available paleomagnetic data in the Devonian, which shows that most data is problematic. Data show directional groups or extreme scatter in many cases. We urge for caution in using Devonian paleopoles for plate tectonic reconstructions, and argue for a revision of the geomagnetic polarity timescale presented for the Devonian, as essentially unknown throughout. We show that many more Devonian paleomagnetic studies are needed to resolve these issues. While there are still many uncertainties regarding the field in the Devonian, based on our review, it is plausible that the field was extremely weak and perhaps had a non-dipolar configuration. We consider it unlikely that any of the other reasons (e.g. pervasive overprinting, unsuitable lithologies, etc.) are the prime cause for the absence of high quality, unambiguous paleomagnetic data during this time period. We here pose the question whether the weak field poorly shielded life on Earth during the Devonian, and was a contributing factor to the many biotic crises in this period.

We strongly emphasise the need for more paleomagnetic data from the Devonian, in particular in the Early and Middle Devonian. There is a general lack of data in all paleomagnetic disciplines; paleopoles, magnetostratigraphy and paleointensity. The lack of paleopoles hampers accurate plate tectonic reconstructions through the Devonian, leading to uncertainty on climatic belts and paleogeographic reconstructions. Due to the lack of magnetostratigraphic data for the Devonian, we cannot assess reversal frequencies, which bear on the understanding of the evolution of the Earth's core and magnetic field. Construction of magnetostratigraphic records is dependent on the nature of the field. If the field is indeed non-dipolar, as has been suggested, construction of a polarity record for parts of the Devonian would be impossible. Increasing the record of paleointensity data in the Devonian will allow assessment of the hypothesised relationship between the magnetic field, biotic crises and true polar wander.

\section{Supplementary materials}

Data from this manuscript are available from the corresponding author upon reasonable request.

All paleomagnetic directional data is supplied as .col files that can be opened in the interpretation portal of www.paleomagnetism.org. Please note that for the Canada and Blankenheim samples, AF steps are in Gauss (10 Gauss $=1 \mathrm{mT})$.

S1 - Blankenheim interpreted directions. File can be opened in the interpretation portal of paleomagnetism.org.

S2 - Blankenheim interpreted directions table.

S3 - Poland interpreted directions. File can be opened in the interpretation portal of paleomagnetism.org.

S4 - Poland interpreted directions table.

S5 - Poland isothermal remanent magnetisation (IRM) curves of all samples.

S6 - Canada interpreted directions. File can be opened in the interpretation portal of paleomagnetism.org.

S7 - Canada interpreted directions table.

S8 - Supplementary methods. 
S9 - Paleofield strength and magnetopause standoff during the Devonian.

S10 - Studies with Devonian paleointensity data included in analysis.

S11 - Field strength and estimated magnetic standoff distance for Devonian data meeting strict selection criteria using $Q_{P I}$ metrics: $A G E+A L T+M D+D I R, N_{I N T}>=3$, and at least 3 sites per 1 Myr age bin. Figure description follows Fig. 21.

S12 - Polar cap angle and relative area for data meeting strict selection criteria. Figure description follows Fig. 23.

S13 - Field strength and estimated magnetic standoff distance for Devonian data meeting lax selection criteria using $Q_{P I}$ metrics: $N_{1 N T}>=3$, and at least one site per 1 Myr age bin. Figure description follows Fig. 21.

S14 - Polar cap angle and relative area for data meeting lax selection criteria. Figure description follows Fig.

23.

\section{Acknowledgements}

This project was funded by Leverhulme Research Leadership award RL-2016-080 (to A. Biggin), and partly by an EPOS-IP (N. 676564) Multi-scale laboratories Trans-national Access pilot grant (to A. van der Boon), which is partly financed by NWO project number ALWIN.010. We thank Dennis Jackson for field assistance in Canada, as well as pilots Dennis Rusch, Thierry Breuls de Tiecken, Leslie MacFarlan, and Ruby McDonald of Norman Wells Renewable Research Council. We thank Jamie Dickson, Paul Warburton, Dawn Abel and Mila Mateeva for their help in measuring paleomagnetic samples. R. Bono was supported by the Leverhulme Trust Early Career Fellowship (ECF-2020-617). Participation of Kabanov, Gouwy, and VandenBerg is supported by GEM GeoNorth Program of NRCan. This research benefited from a travel grant (to A. van der Boon) and in many other ways from UNESCO project IGCP-652 "“"Reading geologic time in Paleozoic sedimentary rocks: the need for an integrated stratigraphy".

\section{Author contributions:}

Samples from Poland were collected on several field trips by A. van der Boon, A. Biggin, M. W. Hounslow, J. Nawrocki, K. Wójcik and M. Paszkowski. Samples from Germany were collected by A. van der Boon, P. Königshof and T. de Backer. Samples from Canada were collected by A. van der Boon, D. Thallner, P. Kabanov, S. Gouwy and R. VandenBerg. Paleomagnetic data collection and interpretation was done by A. van der Boon, A. Biggin, D. Thallner and M. W. Hounslow. Paleointensity synthesis and magnetic standoff estimates were done by R. Bono. Biostratigraphy data collection and interpretation was done by J. Nawrocki, K. Wójcik, M. Paszkowski, P. Königshof, T. de Backer, P. Kabanov, S. Gouwy and R. VandenBerg. All authors contributed to scientific discussion and writing of the manuscript. 


\section{References}

Abrajevitch, A., Van der Voo, R., Levashova, N.M., Bazhenov, M.L., 2007. Paleomagnetic constraints on the paleogeography and oroclinal bending of the Devonian volcanic arc in Kazakhstan. Tectonophysics 441, 67-84. https://doi.org/10.1016/j.tecto.2007.04.008

Aïfa, T., 1993. Different styles of remagnetization in Devonian sediments from the north-western Sahara (Algeria). Geophys. J. Int. 115, 529-537. https://doi.org/10.1111/j.1365-246X.1993.tb01204.x

Aïfa, T., Feinberg, H., Pozzi, J.P., 1990. Devonian-Carboniferous paleopoles for Africa: Consequences for Hercynian geodynamics. Tectonophysics 179, 287-304. https://doi.org/10.1016/0040-1951(90)90295-J

Algeo, T.J., 1996. Geomagnetic polarity bias patterns through the Phanerozoic. J. Geophys. Res. B Solid Earth 101, 2785-2814. https://doi.org/10.1029/95jb02814

Amit, H., Olson, P., 2015. Lower mantle superplume growth excites geomagnetic reversals. Earth Planet. Sci. Lett. 414, 68-76. https://doi.org/10.1016/j.epsl.2015.01.013

Appelt, J., 1998. Tournaisian conodonts from the basinal carbonates of the Krzeszowice area, southern Poland Acta Geol. Pol. 48, 135-140.

Aretz, M., 2021. Late Devonian Extinctions, 2nd ed, Encyclopedia of Geology. Elsevier Ltd. https://doi.org/10.1016/b978-0-12-409548-9.12453-4

Bachtadse, V., Briden, J.C., 1991. Palaeomagnetism of Devonian ring complexes from the Bayuda Desert, Sudan-new constraints on the apparent polar wander path for Gondwanaland. Geophys. J. Int. 104, 635-646. https://doi.org/10.1111/j.1365-246X.1991.tb05707.x

Bachtadse, V., Briden, J.C., 1990. Palaeomagnetic constraints on the position of Gondwana during Ordovician to Devonian times. Geol. Soc. Mem. 12, 43-48. https://doi.org/10.1144/GSL.MEM.1990.012.01.03

Bachtadse, V., Briden, J.C., 1989. Palaeomagnetism of the Early to Mid-Ordovician Salala igneous ring complex, Red Sea Hills, Sudan. Geophys. J. Int. 99, 677-685. https://doi.org/10.1111/j.1365-246X.1989.tb02050.x

Bachtadse, V., Van der Voo, R., Hälbich, I.W., 1987. Paleomagnetism of the western Cape Fold belt, South Africa, and its bearing on the Paleozoic apparent polar wander path for Gondwana. Earth Planet. Sci. Lett. 84, 487-499. https://doi.org/10.1016/0012-821X(87)90013-6

Bąk, M., Dulemba, P., Bąk, K., 2014. Early Carboniferous trilobite remains from limestones of the Dębnik Anticline, southern Poland. Geol. Geophys. Environ. 40, 27-32.

https://doi.org/10.7494/geol.2014.40.1.27

Baker, S.J., Hesselbo, S.P., Lenton, T.M., Duarte, L. V., Belcher, C.M., 2017. Charcoal evidence that rising atmospheric oxygen terminated Early Jurassic ocean anoxia. Nat. Commun. 8, 1-7. https://doi.org/10.1038/ncomms15018

Bambach, R.K., Knoll, A.H., Sepkoski, J.J., 2002. Anatomical and ecological constraints on Phanerozoic animal diversity in the marine realm. Proc. Natl. Acad. Sci. U. S. A. 99, 6854-6859. https://doi.org/10.1073/pnas.092150999

Bazhenov, M.L., Levashova, N.M., Meert, J.G., Golovanova, I. V, Danukalov, K.N., Fedorova, N.M., 2016. Late Ediacaran magnetostratigraphy of Baltica: Evidence for Magnetic Field Hyperactivity? Earth Planet. Sci. Lett. 435, 124-135. https://doi.org/10.1016/j.epsl.2015.12.015

Bazhenov, M.L., Van der Voo, R., Levashova, N.M., Dominguez, A.R., 2013. Late Devonian palaeomagnetism of the North Tien Shan, Kyrgyzstan: Can secular variation vary on a short timescale? Geophys. J. Int. 193, 635-649. https://doi.org/10.1093/gji/ggt011

Becker, R.T., Aboussalam, Z.S., 2011. Emsian Chronostratigraphy - Preliminary new data and a review of the Tafilalt (SE Morocco). SDS Newsl. 26, 33-43. 
Becker, R.T., Aboussalam, Z.S., 2004. The Frasne event - a phased 2nd order global crisis and extinction period, in: Abstracts of the SDS Annual Meeting - Rabat, Morocco. pp. 8-9.

Becker, R.T., House, M.R., 1997. Sea-level changes in the Upper Devonian of the Canning Basin, Western Australia. CFS Cour. Forschungsinstitut Senckenb. 129-146.

Becker, R.T., Königshof, P., Brett, C.E., 2016. Devonian climate, sea level and evolutionary events: An introduction. Geol. Soc. Spec. Publ. 423, 1-10. https://doi.org/10.1144/SP423.15

Becker, R.T., Marshall, J.E.A., Da Silva, A.-C., 2020. The Devonian Period, Geologic Time Scale 2020. BV. https://doi.org/10.1016/B978-0-12-824360-2.00022-X

Becker, T.R., Gradstein, F.M., Hammer, Ø., 2012. The Devonian period, in: The Geologic Time Scale 2012. Elsevier, pp. 559-601. https://doi.org/10.1017/CB09780511536045.015

Becker, T.W., Boschi, L., 2002. A comparison of tomographic and geodynamic mantle models. Geochemistry, Geophys. Geosystems 3, 1-48. https://doi.org/10.1029/2001GC000168

Belka, Z., 1993. Thermal and burial history of the Cracow-Silesia region (southern Poland) assessed by conodont CAl analysis. Tectonophysics 227, 161-190.

Belka, Z., Skompski, S., Sobon-Podgorska, J., 1996. Reconstruction of a lost carbonate platform on the shelf of Fennosarmatia: Evidence from Viséan polymictic debrites, Holy Cross Mountains, Poland. Geol. Soc. Spec. Publ. 107, 315-329. https://doi.org/10.1144/GSL.SP.1996.107.01.22

Biggin, A.J., Bono, R.K., Meduri, D.G., Sprain, C.J., Davies, C.J., Holme, R., Doubrovine, P. V., 2020. Quantitative estimates of average geomagnetic axial dipole dominance in deep geological time. Nat. Commun. 11, 19. https://doi.org/10.1038/s41467-020-19794-7

Biggin, A.J., Paterson, G.A., 2014. A new set of qualitative reliability criteria to aid inferences on palaeomagnetic dipole moment variations through geological time. Front. Earth Sci. 2, 1-9. https://doi.org/10.3389/feart.2014.00024

Biggin, A.J., Piispa, E.J., Pesonen, L.J., Holme, R., Paterson, G.A., Veikkolainen, T., Tauxe, L., 2015. Palaeomagnetic field intensity variations suggest Mesoproterozoic inner-core nucleation. Nature 526, 245-248. https://doi.org/10.1038/nature15523

Biggin, A.J., Steinberger, B., Aubert, J., Suttie, N., Holme, R., Torsvik, T.H., Van Der Meer, D.G., Van Hinsbergen, D.J.J., 2012. Possible links between long-term geomagnetic variations and whole-mantle convection processes. Nat. Geosci. 5, 526-533. https://doi.org/10.1038/ngeo1521

Bono, R.K., Tarduno, J.A., Nimmo, F., Cottrell, R.D., 2019. Young inner core inferred from Ediacaran ultra-low geomagnetic field intensity. Nat. Geosci. 12, 143-147. https://doi.org/10.1038/s41561-018-0288-0

Boyer, D.L., Martinez, A.M., Evans, S.D., Cohen, P.A., Haddad, E.E., Pippenger, K.H., Love, G.D., Droser, M.L., 2021. Living on the edge: The impact of protracted oxygen stress on life in the Late Devonian. Palaeogeogr. Palaeoclimatol. Palaeoecol. 566. https://doi.org/10.1016/j.palaeo.2021.110226

Brett, C.E., Baird, G.C., Bartholomew, A.J., DeSantis, M.K., Ver Straeten, C.A., 2011. Sequence stratigraphy and a revised sea-level curve for the Middle Devonian of eastern North America. Palaeogeogr. Palaeoclimatol. Palaeoecol. 304, 21-53. https://doi.org/10.1016/j.palaeo.2010.10.009

Briden, J.C., 1966. Variation of intensity of the palaeomagnetic field through geological time. Nature 212, 246247. https://doi.org/10.1038/212246a0

Briden, J.C., Turnell, H.B., Watts, D.R., 1984. British paleomagnetism, lapetus Ocean, and the Great Glen fault. Geology 12, 428-431. https://doi.org/10.1130/0091-7613(1984)12<428:BPIOAT>2.0.CO;2

Carmichael, S.K., Waters, J.A., Königshof, P., Suttner, T.J., Kido, E., 2019. Paleogeography and paleoenvironments of the Late Devonian Kellwasser event: A review of its sedimentological and 
geochemical expression. Glob. Planet. Change 183. https://doi.org/10.1016/j.gloplacha.2019.102984

Chen, Z., Li, Z.X., Powell, C.M.A., 1995. Paleomagnetism of the Upper Devonian reef complexes, Canning Basin, Western Australia. Tectonics 14, 154-167. https://doi.org/10.1029/94TC01622

Chen, Z., Li, Z.X., Powell, C.M.A., Balme, B.E., 1993. Palaeomagnetism of the Brewer Conglomerate in central Australia, and fast movement of Gondwanaland during the Late Devonian. Geophys. J. Int. 115, 564-574. https://doi.org/10.1111/j.1365-246X.1993.tb01207.x

Chlupác, I., Kukal, Z., 1988. Possible global events and the stratigraphy of the Palaeozoic of the Barrandian (Cambrian-Middle Devonian, Czechoslovakia). Sborník Geol. věd. Geol. 43, 83-146.

Claesson, C., 1979. Early Palaeozoic geomagnetism of Gotland. Gff 101, 149-155. https://doi.org/10.1080/11035897909452573

Cocks, L.R.M., Torsvik, T.H., 2007. Siberia, the wandering northern terrane, and its changing geography through the Palaeozoic. Earth-Science Rev. 82, 29-74. https://doi.org/10.1016/j.earscirev.2007.02.001

Cocks, L.R.M., Torsvik, T.H., 2002. Earth geography form 500 to 400 million years ago: A faunal and palaeomagnetic review. J. Geol. Soc. London. 159, 631-644. https://doi.org/10.1144/0016-764901-118

Coltice, N., Seton, M., Rolf, T., Müller, R.D., Tackley, P.J., 2013. Convergence of tectonic reconstructions and mantle convection models for significant fluctuations in seafloor spreading. Earth Planet. Sci. Lett. 383, 92-100. https://doi.org/10.1016/j.epsl.2013.09.032

Cottrell, R.D., Tarduno, J.A., Roberts, J., 2008. The Kiaman Reversed Polarity Superchron at Kiama: Toward a field strength estimate based on single silicate crystals. Phys. Earth Planet. Inter. 169, 49-58. https://doi.org/10.1016/j.pepi.2008.07.041

Davies, C., Pozzo, M., Gubbins, D., Alfè, D., 2015. Constraints from material properties on the dynamics and evolution of Earth's core. Nat. Geosci. 8, 678-685. https://doi.org/10.1038/ngeo2492

Davydov, V.I., Korn, D.K., Schmitz, M.D., Gradstein, F.M., Hammer, Ø., 2012. The Carboniferous Period, The Geologic Time Scale 2012. Elsevier. https://doi.org/10.1016/B978-0-444-59425-9.00023-8

De Vleeschouwer, D., Königshof, P., Claeys, P., 2018. Reading time and paleoenvironmental change in the Emsian-Eifelian boundary GSSP section (Wetteldorf, Germany): A combination of cyclostratigraphy and facies analysis. Newsletters Stratigr. 51, 209-226. https://doi.org/10.1127/nos/2017/0397

DeSantis, M.K., Brett, C.E., 2011. Late Eifelian (Middle Devonian) biocrises: Timing and signature of the preKaák Bakoven and Stony Hollow Events in eastern North America. Palaeogeogr. Palaeoclimatol. Palaeoecol. 304, 113-135. https://doi.org/10.1016/j.palaeo.2010.10.013

Didenko, A.N., Pechersky, D.M., 1989. Direction and intensity of the geomagnetic field in the Middle Devonian and Lower Ordovician: southern Mugodjary ophiolites (Urals). Phys. Earth Planet. Inter. 58, 289-306. https://doi.org/10.1016/0031-9201(89)90101-5

Doubrovine, P. V., Veikkolainen, T., Pesonen, L.J., Piispa, E., Ots, S., Smirnov, A. V., Kulakov, E. V., Biggin, A.J., 2019. Latitude Dependence of Geomagnetic Paleosecular Variation and its Relation to the Frequency of Magnetic Reversals: Observations From the Cretaceous and Jurassic. Geochemistry, Geophys. Geosystems 20, 1240-1279. https://doi.org/10.1029/2018GC007863

Driscoll, P., Olson, P., 2011. Superchron cycles driven by variable core heat flow. Geophys. Res. Lett. 38, n/an/a. https://doi.org/10.1029/2011gl046808

Driscoll, P.E., 2016. Simulating 2 Ga of geodynamo history. Geophys. Res. Lett. 43, 5680-5687. https://doi.org/10.1002/2016GL068858

Dunlop, D.J., 2014. High-temperature susceptibility of magnetite: A new pseudo-single-domain effect. Geophys. J. Int. 199, 707-716. https://doi.org/10.1093/gji/ggu247 
Dunlop, D.J., 2011. Physical basis of the Thellier - Thellier and related paleointensity methods. Phys. Earth Planet. Inter. 187, 118-138. https://doi.org/10.1016/j.pepi.2011.03.006

Dunlop, D.J., Özdemir, Ö., 1997. Rock Magnetism - Fundamentals and Frontiers.

Dvorák, J., Galle, A., Herbig, H.-G., Krejci, Z., Malec, J., Paszkowski, M., Racki, G., Skompski, S., Szulczewski, M., Zakowa, H., 1995. Guide to Excursion B4 - Evolution of the Polish-Moravian carbonate platform in the late Devonian and Early Carboniferous: Holy Cross Mts., Karaków upland, Moravian Karst.

Epstein, A.G., Epstein, J.B., Harris, L.D., 1977. Conodont color alteration - an index to organic metamorphism. USGS Prof. Pap. 995, 27pp.

Evans, D.A.D., 2006. Proterozoic low orbital obliquity and axial-dipolar geomagnetic field from evaporite palaeolatitudes. Nature 444, 51-55. https://doi.org/10.1038/nature05203

Fallas, K.M., McNaughton, R.B., 2013. Geology, Norman Wells (southeast), Northwest Territories. Geol. Surv. Canada, Can. Geosci. Map 100. https://doi.org/doi:10.4095/292292

Fanelli, D., 2012. Negative results are disappearing from most disciplines and countries. Scientometrics 90 , 891-904. https://doi.org/10.1007/s11192-011-0494-7

Feist, R., Flajs, G., Girard, C., 2000. The stratotype section of the Devonian-Carboniferous boundary. CFS Cour. Forschungsinstitut Senckenb. 77-82.

Fields, B.D., Melott, A.L., Ellis, J., Ertel, A.F., Fry, B.J., Lieberman, B.S., Liu, Z., Miller, J.A., Thomas, B.C., 2020. Supernova triggers for end-Devonian extinctions. PNAS. https://doi.org/10.1073/pnas.2013774117

Fisher, R., 1953. Dispersion on a sphere. Proc. R. Soc. London 217, 295-305. https://doi.org/10.1098/rspa.1953.0064

Gallet, Y., Pavlov, V., Korovnikov, I., 2019. Extreme geomagnetic reversal frequency during the Middle Cambrian as revealed by the magnetostratigraphy of the Khorbusuonka section (northeastern Siberia). Earth Planet. Sci. Lett. 528. https://doi.org/10.1016/j.epsl.2019.115823

García-Alcalde, J.L., 1997. North Gondwanan Emsian events. Episodes 20, 241-246. https://doi.org/10.18814/epiiugs/1997/v20i4/006

Garcia, A.S., Thomas, D.N., Liss, D., Shaw, J., 2006. Low geomagnetic field intensity during the Kiaman superchron: Thellier and microwave results from the Great Whin Sill intrusive complex, northern United Kingdom. Geophys. Res. Lett. 33, 3-7. https://doi.org/10.1029/2006GL026729

Garza, R.S.M., Zijderveld, J.D.A., 1996. Paleomagnetism of Paleozoic strata, Brabant and Ardennes Massifs, Belgium: Implications of prefolding and postfolding Late Carboniferous secondary magnetizations for European apparent polar wander. J. Geophys. Res. Solid Earth 101, 15799-15818. https://doi.org/10.1029/96jb00325

Gouwy, S.A., 2021. Paper 6. Devonian conodont biostratigraphy of the Mackenzie Mountains (NWT, Canada), in: Lavoie, D., Dewing, K. (Eds.), Sedimentary Basins of the Canadian North - Contributions to a $1000 \mathrm{Ma}$ Geological Journay and Insight on Resource Potential. Geological Survey of Canada, Bulletin 609.

Gouwy, S.A., 2006. Report on 15 conodont samples from the Horn river group (Hare Indian and Canol formations), Prohibition Creek. Geol. Surv. Canada, Paleontol. Rep. 1-15.

Gouwy, S.A., Pedder, A.E.H., Uyeno, T.T., Mackenzie, W.S., 2021. Description of five Devonian sections (Hume River, Gayna River Gorge, Powell Creek Tributatry, Powell Creek and Prohibition Creek) from the northern front of the Mackenzie Mountains and the Franklin Mountains (NWT, Canada). GSC Open File 53.

Gouwy, S.A., Uyeno, T.T., 2018. Lower and lower Middle Devonian Conodont biostratigraphy in the Northern Mackenzie Mountains and adjacent areas (NWT, Canada): Graphic Correlation applied to the Middle 
Devonian Hume Formation and reassessment of the time-rock chart, in: Canadian Paleontology Conference Abstract Book. Saskatoon, pp. 12-13.

Grabowski, J., Nawrocki, J., 2001. Palaeomagnetism of some Devonian carbonates from the Holy Cross Mts. (Central Poland): Large pre-Permian rotations or strain modified palaeomagnetic directions? Geol. Q. 45, 165-178.

Gradstein, F.M., Ogg, J.G., Schmitz, M.D., Ogg, G.M., 2020. Geologic Time Scale 2020. Elsevier.

Gromczakiewicz-Łomnicka, A., 1974. Upper Visean conodont fauna from the Carboniferous limestone north of Krzeszowice (environs of Cracow, Poland). Rocz. Pol. Tow. Geol. la Soc. Geol. Pologne XLIV, 475-481.

Guzhikov, A.Y., 2019. General Magnetostratigraphic Scale: Present Status and Outlook of Development. Recent Adv. Rock Magn. Environ. Magn. Paleomagn. 343-351. https://doi.org/10.1007/978-3-319-90437-5_24

Hance, L., Poty, E., 2006. Hastarian. Geol. Belgica 9, 111-116.

Hansma, J., Tohver, E., Yan, M., Trinajstic, K., Roelofs, B., Peek, S., Slotznick, S.P., Kirschvink, J., Playton, T., Haines, P., Hocking, R., 2015. Late Devonian carbonate magnetostratigraphy from the Oscar and Horse Spring Ranges, Lennard Shelf, Canning Basin, Western Australia. Earth Planet. Sci. Lett. 409, 232-242. https://doi.org/10.1016/j.epsl.2014.10.054

Hargraves, R.B., Dawson, E.M., Van Houten, F.B., 1987. Palaeomagnetism and age of mid-Palaeozoic ring complexes in Niger, West Africa, and tectonic implications. Geophys. J. R. Astron. Soc. 90, 705-729. https://doi.org/10.1111/j.1365-246X.1987.tb00750.x

Hartenfels, S., Becker, R.T., 2016. The global Annulata Events: Review and new data from the Rheris Basin (northern Tafilalt) of SE Morocco, in: Geological Society Special Publication. pp. 291-354. https://doi.org/10.1144/SP423.14

Hartenfels, S., Becker, R.T., 2009. Timing of the global Dasberg crisis - Implications for Famennian eustasy and chronostratigraphy. Stud. Devonian Stratigr. Proc. 2007 Int. Meet. Subcommisiion Devonian Stratigr. IGCP 499 71-97.

Hawkins, L., 2018. A Mid-Paleozoic Dipole Low defined from new paleointensity estimates from Russia and the UK. University of Liverpool.

Hawkins, L.M.A., Anwar, T., Shcherbakova, V. V., Biggin, A.J., Kravchinsky, V.A., Shatsillo, A. V., Pavlov, V.E., 2019. An exceptionally weak Devonian geomagnetic field recorded by the Viluy Traps, Siberia. Earth Planet. Sci. Lett. 506, 134-145. https://doi.org/10.1016/j.epsl.2018.10.035

Hawkins, L.M.A., Grappone, J.M., Sprain, C.J., Saengduean, P., 2020. Intensity of the Earth's magnetic field: evidence for a Mid-Paleozoic dipole low. preprint.

Heslop, D., Roberts, A.P., 2018. A Bayesian Approach to the Paleomagnetic Conglomerate Test. J. Geophys. Res. Solid Earth 123, 1132-1142. https://doi.org/10.1002/2017JB014526

Hounslow, M.W., 2021. A geomagnetic polarity timescale for the Carboniferous. Geol. Soc. London, Spec. Publ. 512, SP512-2020-102. https://doi.org/10.1144/sp512-2020-102

Hounslow, M.W., Balabanov, Y.P., 2018. A geomagnetic polarity timescale for the Permian, calibrated to stage boundaries. Geol. Soc. Spec. Publ. 450, 61-103. https://doi.org/10.1144/SP450.8

Hounslow, M.W., Domeier, M., Biggin, A.J., 2018. Subduction flux modulates the geomagnetic polarity reversal rate. Tectonophysics 742-743, 34-49. https://doi.org/10.1016/j.tecto.2018.05.018

House, M.R., 2002. Strength, timing, setting and cause of mid-Palaeozoic extinctions. Palaeogeogr. Palaeoclimatol. Palaeoecol. 181, 5-25. https://doi.org/10.1016/S0031-0182(01)00471-0

House, M.R., Kirchgasser, W.T., 1993. Devonian goniatite biostratigraphy and timing of facies movements in 
the Frasnian of eastern North America. High Resolut. Stratigr. 267-292.

House, M.R.M.R., Gradstein, F.M.F.M., 2004. The Devonian Period. A Geol. Time Scale 2004 202-221. https://doi.org/10.1017/CBO9780511536045.015

Huang, B., Otofuji, Y.I., Yang, Z., Zhu, R., 2000. New Silurian and Devonian palaeomagnetic results from the Hexi Corridor terrane, northwest China, and their tectonic implications. Geophys. J. Int. 140, 132-146. https://doi.org/10.1046/j.1365-246X.2000.00983.x

Hurley, N.F., Van Der Voo, R., 1987. Paleomagnetism of Upper Devonian reefal limestones, Canning basin, Western Australia. Geol. Soc. Am. Bull. 98, 138-146. https://doi.org/10.1130/00167606(1987)98<138:POUDRL>2.0.CO;2

Iosifidi, A.G., Khramov, A.N., 2013. Paleomagnetism of paleozoic sediments from the Kozhim River section: On the problem of palinspastic reconstructions of the Subpolar Urals and Pai-Khoi. Izv. Phys. Solid Earth 49, 63-76. https://doi.org/10.1134/\$1069351313010059

Irving, E., Strong, D.F., 1985. Paleomagnetism of rocks from Burin Peninsula, Newfoundland: Hypothesis of Late Paleozoic displacement of Acadia criticized. J. Geophys. Res. 90, 1949. https://doi.org/10.1029/jb090ib02p01949

Irving, E., Strong, D.F., 1984. Evidence against large-scale Carboniferous strike-slip faulting in the AppalachianCaledonian orogen. Nature 310, 762-764. https://doi.org/10.1038/310762a0

Isaacson, P.E., Díaz-Martínez, E., Grader, G.W., Kalvoda, J., Babek, O., Devuyst, F.X., 2008. Late Devonianearliest Mississippian glaciation in Gondwanaland and its biogeographic consequences. Palaeogeogr. Palaeoclimatol. Palaeoecol. 268, 126-142. https://doi.org/10.1016/j.palaeo.2008.03.047

Jeleńska, M., Kadziałko-Hofmokl, M., Bakhmutov, V., Poliachenko, I., Ziółkowski, P., 2015. Palaeomagnetic and rock magnetic study of Lower Devonian sediments from Podolia, SW Ukraine: Remagnetization problems. Geophys. J. Int. 200, 557-573. https://doi.org/10.1093/gji/ggu411

Jeleńska, M., Kadzialko-Hofmokl, M., Edel, J.B., Jamrozik, L., Petersen, N., Soffel, H., 1995. Palaeomagnetic investigations of the Palaeozoic circum-Sowie Góry Mountains ophiolitic belt in the Sudetes, Poland. Geophys. J. Int. 122, 658-674. https://doi.org/10.1111/j.1365-246X.1995.tb07018.x

Kabanov, P., n.d. Devonian of the Mackenzie, in: Lavoie, D., Dewing, K. (Eds.), Sedimentary Basins of the Canadian North - Contributions to a 1000 Ma Geological Journay and Insight on Resource Potential. Geologial Survey of Canada.

Kabanov, P., Jiang, C., 2020. Photic-zone euxinia and anoxic events in a Middle-Late Devonian shelfal sea of Panthalassan continental margin, NW Canada: Changing paradigm of Devonian ocean and sea level fluctuations. Glob. Planet. Change 188, 103153. https://doi.org/10.1016/j.gloplacha.2020.103153

Kabanov, P., Vandenberg, R., Gouwy, S., van der Boon, A., Thallner, D., Biggin, A., 2019. Geological and geochemical data from Mackenzie corridor. Part X: reference sections of Middle-Upper Devonian strata at Prohibition Creek, Norman Range, Northwest Territories. Geol. Surv. Canada Open File 8648.

Kadziałko-Hofmokl, M., Jeleńska, M., Aïfa, T., Edel, J.B., Zelaźniewicz, A., 1999. Paleomagnetism and remagnetization of Upper Devonian synorogenic clastic sediments from the Pogorzała Formation (Świebodzice Depression, West Sudetes, Poland). Geol. Sudetica 32, 113-126.

Kaiho, K., Miura, M., Tezuka, M., Hayashi, N., Jones, D.S., Oikawa, K., Casier, J.G., Fujibayashi, M., Chen, Z.Q., 2021. Coronene, mercury, and biomarker data support a link between extinction magnitude and volcanic intensity in the Late Devonian. Glob. Planet. Change 199. https://doi.org/10.1016/j.gloplacha.2021.103452

Kent, D.V., Dia, O., Sougy, J.M.A., 1984. Paleomagnetism of lower-middle Devonian and Upper ProterozoicCambrian(?) rocks from Mejeria (Mauritania, West Africa), in: Plate Reconstruction From Paleozoic 
Paleomagnetism. pp. 99-115. https://doi.org/10.1029/gd012p0099

Kent, D. V., 1979. Paleomagnetism of the Devonian Onondaga limestone revisited. J. Geophys. Res. 84, 35763588. https://doi.org/10.1029/JB084iB07p03576

Kent, D. V., Olsen, P.E., Lepre, C., Rasmussen, C., Mundil, R., Gehrels, G.E., Giesler, D., Irmis, R.B., Geissman, J.W., Parker, W.G., 2019. Magnetochronology of the Entire Chinle Formation (Norian Age) in a Scientific Drill Core From Petrified Forest National Park (Arizona, USA) and Implications for Regional and Global Correlations in the Late Triassic. Geochemistry, Geophys. Geosystems 20, 4654-4664. https://doi.org/10.1029/2019GC008474

Khramov, A.N., 1967. Importance of Palaeomagnetic data for Devonian Stratigraphy and Palaeogeography in the USSR. Intl. Symp. Devonian Syst. Pap. II, 1363-1370.

Khramov, A.N., Shkatova, V.K., 2000. Phanerozoic general magnetostratigraphic scale of polarity. Adj. 9 (in Russian). Addit. to Stratigr. Codes Russ. 24-45.

Kiessling, W., Flügel, E., Golonka, J., 2003. Patterns of Phanerozoic carbonate platform sedimentation, Lethaia. https://doi.org/10.1080/00241160310004648

Kirschvink, J.L., 1980. The least-squares line and plane and the analysis of palaeomagnetic data. Geophys. J. Int. 62, 699-718. https://doi.org/10.1111/j.1365-246X.1980.tb02601.x

Knight, K.B., Nomade, S., Renne, P.R., Marzoli, a., Bertrand, H., Youbi, N., 2004. The Central Atlantic Magmatic Province at the Triassic-Jurassic boundary: paleomagnetic and 40Ar/39Ar evidence from Morocco for brief, episodic volcanism. Earth Planet. Sci. Lett. 228, 143-160.

https://doi.org/10.1016/j.epsl.2004.09.022

Kodama, K.P., 2020. A High Reversal Rate (10 reversals/Ma) Observed in the Ediacaran Rainstorm member of the Johnnie Formation Calibrated by Rock Magnetic Cyclostratigraphy. AGU Fall Meet. Abstr.

Kodama, K.P., Carnes, L.K., Tarduno, J.A., Berti, C., 2019. Palaeointensity of the 1.3 billion-yr-old Gardar basalts, southern Greenland revisited: No evidence for onset of inner core growth. Geophys. J. Int. 217, 19741987. https://doi.org/10.1093/gji/ggz126

Kolesov, E.V., 2007. Magnetostratigraphic timescale of the Paleozoic Northeast Russia and transregional correlation. Bull. North-Eastern Sci. Cent. 4, 31-42.

Kolesov, Y. V., 2005. Magnetostratigraphy of Paleozoic in North-East of Russia (in Russian). Magdan, NESC FEB RAS.

Kolesov, Y. V., 1984. Paleomagnetic stratigraphy of the Devonian-Carboniferous boundary beds in the Soviet north-east and in the Franco-Belgian basin. Ann. la Société Géologique Belgique 107, 135-136.

Königshof, P., 2003. Conodont deformation patterns and textural alteration in Paleozoic conodonts: examples from Germany and France. Senckenbergiana Lethaea 83, 149-156. https://doi.org/10.1007/bf03043310

Königshof, P., Da Silva, A.-C.C., Suttner, T.J., Kido, E., Waters, J., Carmichael, S.K., Jansen, U., Pas, D., Spassov, S., 2016. Shallow-water facies setting around the Kačák Event: A multidisciplinary approach. Geol. Soc. London, Spec. Publ. 423, 171-199. https://doi.org/http://doi.org/10.1144/SP423.4

Koymans, M.R., Langereis, C.G., Pastor-Galán, D., van Hinsbergen, D.J.J., 2016. Paleomagnetism.org: an online multi-platform open source environment for paleomagnetic data analysis. Comput. Geosci. 93, 127-137. https://doi.org/10.1016/j.cageo.2016.05.007

Koymans, M.R., van Hinsbergen, D.J.J., Pastor-Galán, D., Vaes, B., Langereis, C.G., 2020. Towards FAIR Paleomagnetic Data Management Through Paleomagnetism.org 2.0. Geochemistry, Geophys. Geosystems 21, 1-7. https://doi.org/10.1029/2019GC008838

Kravchinsky, V.A., 2012. Paleozoic large igneous provinces of Northern Eurasia: Correlation with mass 
extinction events. Glob. Planet. Change 86-87, 31-36. https://doi.org/10.1016/j.gloplacha.2012.01.007

Kravchinsky, V.A., Konstantinov, K.M., Courtillot, V., Savrasov, J.I., Valet, J.P., Cherniy, S.D., Mishenin, S.G., Parasotka, B.S., 2002. Paleomagnetism of East Siberian traps and kimberlites: Two new poles and palaeogeographic reconstructions at about 360 and 250 Ma. Geophys. J. Int. 148, 1-33. https://doi.org/10.1046/j.0956-540x.2001.01548.x

Kulakov, E. V., Sprain, C.J., Doubrovine, P. V., Smirnov, A. V., Paterson, G.A., Hawkins, L., Fairchild, L., Piispa, E.J., Biggin, A.J., 2019. Analysis of an Updated Paleointensity Database (QPI-PINT) for 65-200 Ma: Implications for the Long-Term History of Dipole Moment Through the Mesozoic. J. Geophys. Res. Solid Earth 124, 9999-10022. https://doi.org/10.1029/2018JB017287

Kutterolf, S., Hansteen, T.H., Appel, K., Freundt, A., Krüger, K., Pérez, W., Wehrmann, H., 2013. Combined bromine and chlorine release from large explosive volcanic eruptions: A threat to stratospheric ozone? Geology 41, 707-710. https://doi.org/10.1130/G34044.1

Łaptaś, A., 1982. Sedimentation of the Middle Devonian carbonates in the Dębnik region. Stud. Geol. Pol. 75, 59-100.

Le Hir, G., Donnadieu, Y., Goddéris, Y., Meyer-Berthaud, B., Ramstein, G., Blakey, R.C., 2011. The climate change caused by the land plant invasion in the Devonian. Earth Planet. Sci. Lett. 310, 203-212. https://doi.org/10.1016/j.epsl.2011.08.042

Lenton, T.M., Daines, S.J., Mills, B.J.W., 2018. COPSE reloaded: An improved model of biogeochemical cycling over Phanerozoic time. Earth-Science Rev. 178, 1-28. https://doi.org/10.1016/j.earscirev.2017.12.004

Levashova, N.M., Degtyarev, K.E., Bazhenov, M.L., Collins, A.Q., Van der Voo, R., 2003. Middle Paleozoic paleomagnetism of east Kazakhstan: Post-Middle Devonian rotations in a large-scale orocline in the central Ural-Mongol belt. Tectonophysics 377, 249-268. https://doi.org/10.1016/j.tecto.2003.09.013

Levashova, N.M., Mikolaichuk, A. V., McCausland, P.J.A., Bazhenov, M.L., Van der Voo, R., 2007. Devonian paleomagnetism of the North Tien Shan: Implications for the middle-Late Paleozoic paleogeography of Eurasia. Earth Planet. Sci. Lett. 257, 104-120. https://doi.org/10.1016/j.epsl.2007.02.025

Lewandowski, M., 1995. Palaeomagnetic constraints for Variscan mobilism of the Upper Silesian and Malopolska Massifs, southern Poland - reply. Kwart. Geol. 39, 211-229.

Liu, H., Bai, Z., Wang, H., Yaskawa, K., 1991. Search for the geomagnetic reversal near the DevonianCarboniferous boundary. J. Geomagn. Geoelectr. 43, 755-764. https://doi.org/10.5636/jgg.43.755

Livermore, R.A., Smith, A.G., Briden, J.C., 1985. Palaeomagnetic constraints on the distribution of continents in the late Silurian and early Devonian. Philos. Trans. R. Soc. London. B, Biol. Sci. 309, 29-56. https://doi.org/10.1098/rstb.1985.0069

Lottmann, J., 1990. The Middle Givetian pumilio-Events a tool for high time resolution and eventstratigraphical correlation. Extinction Events Earth Hist. 145-149. https://doi.org/10.1007/bfb0011142

Løvlie, R., Torsvik, T., Jelenska, M., Levandowski, M., 1984. Evidence for detrital remanent magnetization carried by hematite in Devonian red beds from Spitsbergen; palaeomagnetic implications. Geophys. J. R. Astron. Soc. 79, 573-588. https://doi.org/10.1111/j.1365-246X.1984.tb02242.x

Mac Niocaill, C., Smethurst, M.A., 1994. Palaeozoic palaeogeography of Laurentia and its margins: a reassessment of palaeomagnetic data. Geophys. J. Int. 116, 715-725. https://doi.org/10.1111/j.1365246X.1994.tb03292.x

Małkowski, K., Racki, G., 2009. A global biogeochemical perturbation across the Silurian-Devonian boundary: Ocean-continent-biosphere feedbacks. Palaeogeogr. Palaeoclimatol. Palaeoecol. https://doi.org/10.1016/j.palaeo.2009.03.010

Maron, M., Muttoni, G., Rigo, M., Gianolla, P., Kent, D. V., 2019. New magnetobiostratigraphic results from the 
Ladinian of the Dolomites and implications for the Triassic geomagnetic polarity timescale. Palaeogeogr. Palaeoclimatol. Palaeoecol. 517, 52-73. https://doi.org/10.1016/j.palaeo.2018.11.024

Marshall, J.E.A., 2020. A terrestrial Devonian-Carboniferous boundary section in East Greenland. Palaeobiodiversity and Palaeoenvironments. https://doi.org/10.1007/s12549-020-00448-x

Marshall, J.E.A., Lakin, J., Troth, I., Wallace-Johnson, S.M., 2020. UV-B radiation was the DevonianCarboniferous boundary terrestrial extinction kill mechanism. Sci. Adv. 6, 1-9.

Martin, D.L., 1975. Devonian Columbus Limestone of Ohio: a Possible Stratigraphic Tool. Tectonophysics 28, 125-134.

McCabe, C., Elmore, R.D., 1989. The occurrence and origin of Late Paleozoic remagnetization in the sedimentary rocks of North America. Rev. Geophys. 27, 471-494. https://doi.org/10.1029/RG027i004p00471

McFadden, P.L., McElhinny, M.W., 1988. The combined analysis of remagnetization circles and direct observations in palaeomagnetism. Earth Planet. Sci. Lett. 87, 161-172.

McFadden, P.L., Merrill, R.T., 1984. Lower mantle convection and geomagnetism. J. Geophys. Res. 89, 33543362. https://doi.org/10.1029/JB089iB05p03354

McGhee, G.R., Clapham, M.E., Sheehan, P.M., Bottjer, D.J., Droser, M.L., 2013. A new ecological-severity ranking of major Phanerozoic biodiversity crises. Palaeogeogr. Palaeoclimatol. Palaeoecol. 370, 260-270. https://doi.org/10.1016/j.palaeo.2012.12.019

McGhee, G.R., Racki, G., 2021. Extinction: Late Devonian mass extinction. eLS 2, 1-12. https://doi.org/10.1002/9780470015902.a0029301

Meert, J.G., Levashova, N.M., Bazhenov, M.L., Landing, E., 2016. Rapid changes of magnetic Field polarity in the late Ediacaran: Linking the Cambrian evolutionary radiation and increased UV-B radiation. Gondwana Res. 34, 149-157. https://doi.org/10.1016/j.gr.2016.01.001

Montañez, I.P., Poulsen, C.J., 2013. The late Paleozoic ice age: An evolving paradigm. Annu. Rev. Earth Planet. Sci. 41, 629-656. https://doi.org/10.1146/annurev.earth.031208.100118

Morel, P., Irving, E., 1978. Tentative Paleocontinental Maps for the Early Phanerozoic and Proterozoic. J. Geol. 86, 535-561. https://doi.org/10.1086/649724

Mullender, T.A.T., Frederichs, T., Hilgenfeldt, C., de Groot, L. V., Fabian, K., Dekkers, M.J., 2016. Automated paleomagnetic and rock magnetic data acquisition with an in-line horizontal "2G" system. Geochemistry, Geophys. Geosystems 17, 3546-3559. https://doi.org/10.1002/2016GC006436

Mullender, T.A.T., Velzen, A.J., Dekkers, M.J., 1993. Continuous drift correction and separate identification of ferrimagnetic and paramagnetic contributions in thermomagnetic runs. Geophys. J. Int. 114, 663-672. https://doi.org/10.1111/j.1365-246X.1993.tb06995.x

Narkiewicz, M., Racki, G., 1984. Stratigraphy of the Devonian of the Debnik anticline. Kwart. Geol. 28, 513-546.

Nawrocki, J., 1995. Palaeomagnetic constraints for Variscan mobilism of the Upper Silesian and Malopolska Massifs, southern Poland - discussion. Kwart. Geol. 39, 211-229.

Nawrocki, J., 1993. The Devonian-Carboniferous platform paleomagnetic directions from the Silesian-Cracow area and their importance for Variscan paleotectonic reconstructions. Kwart. Geol. 37, 397-430.

Niedźwiedzki, G., Szrek, P., Narkiewicz, K., Narkiewicz, M., Ahlberg, P.E., 2010. Tetrapod trackways from the early Middle Devonian period of Poland. Nature 463, 43-48. https://doi.org/10.1038/nature08623

Ogg, J.G., Ogg, G.M., Gradstein, F.M., 2016a. Devonian. A Concise Geol. Time Scale 1996, 85-103. https://doi.org/10.1002/9781444313413.ch3 
Ogg, J.G., Ogg, G.M., Gradstein, F.M., 2016b. Carboniferous. A Concise Geol. Time Scale 99-113. https://doi.org/10.1007/BF00812525

Ogg, J.G., Smith, A.G., 2004. The geomagnetic polarity time scale. A Geol. Time Scale $200463-86$. https://doi.org/10.1017/CBO9780511536045.006

Paschall, O., Carmichael, S.K., Königshof, P., Waters, J.A., Ta, P.H., Komatsu, T., Dombrowski, A., 2019. The Devonian-Carboniferous boundary in Vietnam: Sustained ocean anoxia with a volcanic trigger for the Hangenberg Crisis? Glob. Planet. Change 175, 64-81. https://doi.org/10.1016/j.gloplacha.2019.01.021

Pastor-Galán, D., Ursem, B., Meere, P.A., Langereis, C., 2015. Extending the Cantabrian Orocline to two continents (from Gondwana to Laurussia). Paleomagnetism from South Ireland. Earth Planet. Sci. Lett. 432, 223-231. https://doi.org/10.1016/j.epsl.2015.10.019

Pedder, A.E.H., 2017. Benthic biostratigraphy of the upper Eifelian (Devonian) Hume Formation at Hume River (type locality), northern Mackenzie Mountains, Northwest Territories, Canada. Stratigraphy 14, 349-364.

Percival, L.M.E., Selby, D., Bond, D.P.G., Rakociński, M., Racki, G., Marynowski, L., Adatte, T., Spangenberg, J.E., Föllmi, K.B., 2019. Pulses of enhanced continental weathering associated with multiple Late Devonian climate perturbations: Evidence from osmium-isotope compositions. Palaeogeogr. Palaeoclimatol. Palaeoecol. 524, 240-249. https://doi.org/10.1016/j.palaeo.2019.03.036

Peters, K.E., Cassa, M.R., 1994. Applied source rock geochemistry. Pet. Syst. - from source to trap.

Piper, J.D.A., 2007. Palaeomagnetism of the Loch Doon Granite Complex, Southern Uplands of Scotland: The Late Caledonian palaeomagnetic record and an Early Devonian episode of True Polar Wander. Tectonophysics 432, 133-157. https://doi.org/10.1016/j.tecto.2006.12.009

Piper, J.D.A., 2006. A 90 Late Silurian-Early Devonian apparent polar wander loop: The latest inertial interchange of planet earth? Earth Planet. Sci. Lett. 250, 345-357. https://doi.org/10.1016/j.epsl.2006.08.001

Pisarzowska, A., Rakociński, M., Marynowski, L., Szczerba, M., Thoby, M., Paszkowski, M., Perri, M.C., Spalletta, C., Schönlaub, H.P., Kowalik, N., Gereke, M., 2020. Large environmental disturbances caused by magmatic activity during the Late Devonian Hangenberg Crisis. Glob. Planet. Change 190, 103155. https://doi.org/10.1016/j.gloplacha.2020.103155

Poty, E., Berkowski, B., Chevalier, E., Hance, L., 2003. Biostratigraphic and sequence stratigraphic correlations between the Dinantian deposits of Belgium and Southern Poland (Krakow area), in: Proceedings of the XVth International Congress on Carboniferous and Permian Stratigraphy. Utrecht, the Netherlands, 10-16 August 2003. pp. 97-107.

Powerman, V., Shatsillo, A., Coe, R., Zhao, X., Gladkochub, D., Buchwaldt, R., Pavlov, V., 2013. Palaeogeography of the Siberian platform during middle Palaeozoic Times ( 450-400 Ma): New palaeomagnetic evidence from the Lena and Nyuya rivers. Geophys. J. Int. 194, 1412-1440. https://doi.org/10.1093/gji/ggt197

Prestianni, C., Gerrienne, P., 2010. Early seed plant radiation: An ecological hypothesis. Geol. Soc. Spec. Publ. 339, 71-80. https://doi.org/10.1144/SP339.7

Pullaiah, G., Irving, E., Buchan, K.L., Dunlop, D.J., 1975. Magnetization changes caused by burial and uplift. Earth Planet. Sci. Lett. 28, 133-143. https://doi.org/10.1016/0012-821X(75)90221-6

Racki, G., 2020. A volcanic scenario for the Frasnian-Famennian major biotic crisis and other Late Devonian global changes: More answers than questions? Glob. Planet. Change 189. https://doi.org/10.1016/j.gloplacha.2020.103174

Racki, G., Piechota, A., Bond, D., Wignall, P.B., 2004. Geochemical and ecological aspects of lower Frasnian pyrite-ammonoid level at Kostomłoty (Holy Cross Mountains, Poland). Geol. Q. 48, 267-282.

Racki, G., Rakocinski, M., Marynowski, L., Wignall, P.B., 2018. Mercury enrichments and the Frasnian- 
Famennian biotic crisis: A volcanic trigger proved? Geology 46, 543-546.

https://doi.org/10.1130/G40233.1

Rejebian, V.A., Harris, A.G., Huebner, J.S., 1987. Conodont color and textural alteration: An index to regional metamorphism, contact metamorphism and hydrothermal alteration. Bull. Geol. Soc. Am. 99, 471-479. https://doi.org/10.1130/0016-7606(1987)99<471:CCATAA>2.0.CO;2

Ribbert, K.-H., 1983. Geologische Karte von Nordrhein-Westfalen 1: 25000 Erlauterungen 5505 Blankenheim. Geol. Karte von Nord. 125000 55-5.

Roberts, A.P., Almeida, T.P., Church, N.S., Harrison, R.J., Heslop, D., Li, Y., Li, J., Muxworthy, A.R., Williams, W., Zhao, X., 2017. Resolving the Origin of Pseudo-Single Domain Magnetic Behavior. J. Geophys. Res. Solid Earth 122, 9534-9558. https://doi.org/10.1002/2017JB014860

Rosenqvist, L., Opgenoorth, H., Buchert, S., McCrea, I., Amm, O., Lathuillere, C., 2005. Extreme solar-terrestrial events of October 2003: High-latitude and Cluster observations of the large geomagnetic disturbances on 30 October. J. Geophys. Res. Sp. Phys. 110. https://doi.org/10.1029/2004JA010927

Sallomy, J.T., Piper, J.D.A., 1973. Palaeomagnetic Studies in the British Caledonides - II The Younger Gabbros of Aberdeenshire, Scotland. Geophys. J. R. Astron. Soc. 34, 13-25. https://doi.org/10.1111/j.1365246X.1973.tb02383.x

Sandberg, C.A., Morrow, J.R., Ziegler, W., 2002. Late Devonian sea-level changes, catastrophic events, and mass extinctions. Spec. Pap. Geol. Soc. Am. 356, 473-487. https://doi.org/10.1130/0-8137-2356-6.473

Schmidt, P.W., Embleton, B.J.J., Cudahy, T.J., Powell, C.M.A., 1986. Prefolding and premegakinking magnetizations from the Devonian Comerong Volcanics, New South Wales, Australia, and their bearing on the Gondwana Pole Path. Tectonics 5, 135-150. https://doi.org/10.1029/TC005i001p00135

Self, S., 2015. Explosive Super-Eruptions and Potential Global Impacts, Volcanic Hazards, Risks, and Disasters. Elsevier Inc. https://doi.org/10.1016/B978-0-12-396453-3.00016-2

Selkin, P.A., Tauxe, L., 2000. Long-term variations in palaeointensity. Philos. Trans. R. Soc. A Math. Phys. Eng. Sci. 358, 1065-1088. https://doi.org/10.1098/rsta.2000.0574

Shatsillo, A. V., Pavlov, V.E., 2019. Systematics of Paleomagnetic Directions from Early-Middle Devonian Rocks of Minusa Troughs: New Data and Old Problems. Izv. Phys. Solid Earth 55, 471-487. https://doi.org/10.1134/S1069351319030091

Shcherbakova, V. V., Bakhmutov, V.G., Thallner, D., Shcherbakov, V.P., Zhidkov, G. V., Biggin, A.J., 2020. Ultralow palaeointensities from East European Craton, Ukraine support a globally anomalous palaeomagnetic field in the Ediacaran. Geophys. J. Int. 220, 1920-1946. https://doi.org/10.1093/gji/ggz566

Shcherbakova, V. V., Biggin, A.J., Veselovskiy, R. V., Shatsillo, A. V., Hawkins, L.M.A., Shcherbakov, V.P., Zhidkov, G. V., 2017. Was the Devonian geomagnetic field dipolar or multipolar? Palaeointensity studies of Devonian igneous rocks from the Minusa Basin (Siberia) and the Kola Peninsula dykes, Russia. Geophys. J. Int. 209, 1265-1286. https://doi.org/10.1093/gji/ggx085

Siscoe, G.L., Chen, C.-K., 1975. The paleomagnetosphere. J. Geophys. Res. 80, 4675-4680. https://doi.org/10.1029/ja080i034p04675

Smethurst, M.A., Khramov, A.N., 1992. A new Devonian palaeomagnetic pole for the Russian platform and Baltica, and related apparent polar wander. Geophys. J. Int. 108, 179-192. https://doi.org/10.1111/j.1365-246X.1992.tb00848.x

Smirnov, A. V., Kulakov, E. V., Foucher, M.S., Bristol, K.E., 2017. Intrinsic paleointensity bias and the long-term history of the geodynamo. Sci. Adv. 3, 1-8. https://doi.org/10.1126/sciadv.1602306

Smirnov, A. V., Tarduno, J.A., Kulakov, E. V., McEnroe, S.A., Bono, R.K., 2016. Palaeointensity, core thermal conductivity and the unknown age of the inner core. Geophys. J. Int. 205, 1190-1195. 
https://doi.org/10.1093/gji/ggw080

Sprain, C.J., Swanson-Hysell, N.L., Fairchild, L.M., Gaastra, K., 2018. A field like today's? The strength of the geomagnetic field 1.1 billion years ago. Geophys. J. Int. 213, 1969-1983. https://doi.org/10.1093/gji/ggy074

Stadelmann, A., 2004. Globale Effekte einer Erdmagnetfeldumkehrung: Magnetosphärenstruktur und kosmische Teilchen. Braunschweig.

Stearns, C., Van Der Voo, R., Abrahamsen, N., 1989. A new Siluro-Devonian paleopole from Early Paleozoic rocks of the Franklinian Basin, North Greenland Fold Belt. J. Geophys. Res. 94, 669-683. https://doi.org/10.1029/jb094ib08p10669

Strother, P.K., Servais, T., Vecoli, M., 2010. The effects of terrestrialization on marine ecosystems: The fall of CO2. Geol. Soc. Spec. Publ. 339, 37-48. https://doi.org/10.1144/SP339.4

Szulczewski, M., Dvorák, J., 1995. Evolution of the Polish-Moravian carbonate platform in the Late Devonian and Early Carboniferous: Holy Cross Mts., Kraków Upland, Moravian Karst.

Tarduno, J.A., Cottrell, R.D., Smirnov, A. V., 2002. The Cretaceous superchron geodynamo: Observations near the tangent cylinder. Proc. Natl. Acad. Sci. U. S. A. 99, 14020-14025.

https://doi.org/10.1073/pnas.222373499

Tarduno, J.A., Cottrell, R.D., Watkeys, M.K., Hofmann, A., Doubrovine, P. V., Mamajek, E.E., Liu, D., Sibeck, D.G., Neukirch, L.P., Usui, Y., 2010. Geodynamo, solar wind, and magnetopause 3.4 to 3.45 billion years ago. Science 327, 1238-1240. https://doi.org/10.1126/science.1183445

Tauxe, L., 2010. Essentials of Paleomagnetism. Essentials Paleomagn. 512. https://doi.org/10.1525/9780520946378

Tauxe, L., Yamazaki, T., 2007. Paleointensities, in: Treatise on Geophysics. https://doi.org/10.1016/B978044452748-6.00098-5

Thallner, D., Biggin, A., Halls, H., 2020. The Ediacaran Grenville dykes (SE Canada) reveal the weakest sustained palaeomagnetic field on record. EarthArXiv Prepr.

Thébault, E., Finlay, C.C., Beggan, C.D., Alken, P., Aubert, J., Barrois, O., Bertrand, F., Bondar, T., Boness, A., Brocco, L., Canet, E., Chambodut, A., Chulliat, A., Coïsson, P., Civet, F., Du, A., Fournier, A., Fratter, I., Gillet, N., Hamilton, B., Hamoudi, M., Hulot, G., Jager, T., Korte, M., Kuang, W., Lalanne, X., Langlais, B., Léger, J.M., Lesur, V., Lowes, F.J., Macmillan, S., Mandea, M., Manoj, C., Maus, S., Olsen, N., Petrov, V., Ridley, V., Rother, M., Sabaka, T.J., Saturnino, D., Schachtschneider, R., Sirol, O., Tangborn, A., Thomson, A., Tøffner-Clausen, L., Vigneron, P., Wardinski, I., Zvereva, T., 2015. International geomagnetic reference field: The 12th generation international geomagnetic reference field - The twelfth generation. Earth, Planets Sp. 67. https://doi.org/10.1186/s40623-015-0228-9

Thorning, L., 1974. Palaeomagnetic Results from Lower Devonian Rocks of the Cheviot Hills, Northern England. Geophys. J. R. Astron. Soc. 36, 487-496. https://doi.org/10.1111/j.1365-246X.1974.tb03650.x

Tonarová, P., Vodrážková, S., Ferrová, L., de la Puente, G.S., Hints, O., Frýda, J., Kubajko, M., 2017. Palynology, microfacies and biostratigraphy across the Daleje Event (Lower Devonian, lower to upper Emsian): new insights from the offshore facies of the Prague Basin, Czech Republic. Palaeobiodiversity and Palaeoenvironments 97, 419-438. https://doi.org/10.1007/s12549-017-0274-3

Torsvik, T.H., 2019. Earth history: A journey in time and space from base to top. Tectonophysics 760, $297-313$. https://doi.org/10.1016/j.tecto.2018.09.009

Torsvik, T.H., Cocks, L.R.M., 2013. New global palaeogeographical reconstructions for the Early Palaeozoic and their generation. Geol. Soc. Mem. 38, 5-24. https://doi.org/10.1144/M38.2

Torsvik, T.H., Van Der Voo, R., Doubrovine, P. V., Burke, K., Steinberger, B., Ashwal, L.D., Trønnes, R.G., Webb, 
S.J., Bull, A.L., 2014. Deep mantle structure as a reference frame for movements in and on the Earth. Proc. Natl. Acad. Sci. U. S. A. 111, 8735-8740. https://doi.org/10.1073/pnas.1318135111

Torsvik, T.H., Voo, R. Van Der, Preeden, U., Mac, C., Steinberger, B., Doubrovine, P. V., Hinsbergen, D.J.J. Van, Domeier, M., Gaina, C., Tohver, E., Meert, J.G., McCausland, P.J.A., Cocks, L.R.M., 2012. Phanerozoic polar wander, palaeogeography and dynamics. Earth-Science Rev. https://doi.org/10.1016/j.earscirev.2012.06.002

Tsandev, I., Slomp, C.P., 2009. Modeling phosphorus cycling and carbon burial during Cretaceous Oceanic Anoxic Events. Earth Planet. Sci. Lett. 286, 71-79. https://doi.org/10.1016/j.epsl.2009.06.016

Uyeno, T.T., Pedder, A.E.H., Uyeno, T.A., 2017. Conodont biostratigraphy and T-R cycles of the Middle Devonian Hume Formation at Hume River (type locality), northern Mackenzie Mountains, Northwest Territories, Canada. Stratigraphy 14, 391-404. https://doi.org/10.29041/strat.14.1-4.391-404

Van Der Boon, A., Kuiper, K.F., Villa, G., Renema, W., Meijers, M.J.M., Langereis, C.G., Aliyeva, E., Krijgsman, W., 2017. Onset of Maikop sedimentation and cessation of Eocene arc volcanism in the Talysh Mountains, Azerbaijan. Geol. Soc. London, Spec. Publ. 428, 145-169. https://doi.org/10.1144/sp428.3

van der Voo, R., 1994. True polar wander during the middle Paleozoic? Earth Planet. Sci. Lett. 122, 239-243.

Van der Voo, R., 1990. The reliability of paleomagnetic data. Tectonophysics 184, 1-9. https://doi.org/10.1016/0040-1951(90)90116-P

van Velzen, A.J.J., Zijderveld, J.D.A.D.A., 1995. Effects of weathering on single-domain magnetite in Early Pliocene marine mark. Geophys. J. Int. 121, 267-278. https://doi.org/10.1111/j.1365246X.1995.tb03526.x

Vérard, C., 2004. Palaeozoic Palaeomagnetism of South-Eastern Australia: Implications for the APW path of Gondwana 217.

Vogt, J., Zieger, B., Glassmeier, K.H., Stadelmann, A., Kallenrode, M.B., Sinnhuber, M., Winkler, H., 2007. Energetic particles in the paleomagnetosphere: Reduced dipole configurations and quadrupolar contributions. J. Geophys. Res. Sp. Phys. 112, 1-13. https://doi.org/10.1029/2006JA012224

Voigt, G.H., 1995. Magnetospheric configuration, Handbook of Atmospheric Electrodynamics. https://doi.org/10.1201/9780203713297

Walliser, O.H., 1996. Global Events in the Devonian and Carboniferous, in: Global Events and Event Stratigraphy in the Phanerozoic. pp. 225-250. https://doi.org/10.1007/978-3-642-79634-0_11

Witzke, B.J., 1990. Palaeoclimates constrains for palaeozoic Palaeolatitudes of Laurentia and Euramerica. Geol. Soc. Mem. 12, 57-73. https://doi.org/10.1144/GSL.MEM.1990.012.01.05

Witzke, B.J., Heckel, P.H., 1988. Paleoclimatic indicators and inferred Devonian paleolatitudes of Euramerica. Devonian of the World 14, 49-63.

Wójcik, K., 2012. Famennian Fusulinina (Foraminifera) from the Holy Cross Mountains (central Poland). Geol. J. 47, 594-615. https://doi.org/10.1002/gj.2419

Wolniewicz, P., 2009. Late Famennian Stromatoporoids from Dębnik Anticline, Southern Poland. Acta Palaeontol. Pol. 54, 337-350. https://doi.org/10.4202/app.2007.0096

Zegers, T.E., Dekkers, M.J., Bailly, S., 2003. Late Carboniferous to Permian remagnetization of Devonian limestones in the Ardennes: Role of temperature, fluids, and deformation. J. Geophys. Res. Solid Earth 108, n/a-n/a. https://doi.org/10.1029/2002JB002213

Zhang, Y., Hou, M., Liu, G., Zhang, C., Prakapenka, V.B., Greenberg, E., Fei, Y., Cohen, R.E., Lin, J.F., 2020. Reconciliation of Experiments and Theory on Transport Properties of Iron and the Geodynamo. Phys. Rev. Lett. 125, 78501. https://doi.org/10.1103/PhysRevLett.125.078501 
Ziegler, W., Sandberg, C.A., 1997. Proposal of boundaries for a Late Frasnian Substage and for subdivision of the Famennian Stage into three Substages. SDS Newsl. 14, 11-12.

Zijderveld, J.D.A., 1967. AC demagnetization of rocks: analysis of results, in: Collinson, D.W., Creer, K.M. (Eds.), Methods in Paleomagnetism. Elsevier, Amsterdam, pp. 254-286.

Zwing, A., Bachtadse, V., 2000. Paleoposition of the northern margin of Armorica in Late Devonian times: Paleomagnetic and rock magnetic results from the Frankenstein Intrusive Complex (Mid-German Crystalline Rise). J. Geophys. Res. Solid Earth 105, 21445-21456. https://doi.org/10.1029/2000jb900167 